\title{
IUCN
}

\section{IUCN World Heritage Outlook 3}

A conservation assessment of all natural World Heritage sites November 2020 


\section{About IUCN}

IUCN is a membership Union uniquely composed of both government and civil society organisations. It provides public, private and non-governmental organisations with the knowledge and tools that enable human progress, economic development and nature conservation to take place together.

Created in 1948, IUCN is now the world's largest and most diverse environmental network, harnessing the knowledge, resources and reach of more than 1,400 Member organisations and some 15,000 experts. It is a leading provider of conservation data, assessments and analysis. Its broad membership enables IUCN to fill the role of incubator and trusted repository of best practices, tools and international standards.

IUCN provides a neutral space in which diverse stakeholders including governments, NGOs, scientists, businesses, local communities, indigenous peoples organisations and others can work together to forge and implement solutions to environmental challenges and achieve sustainable development.

Working with many partners and supporters, IUCN implements a large and diverse portfolio of conservation projects worldwide. Combining the latest science with the traditional knowledge of local communities, these projects work to reverse habitat loss, restore ecosystems and improve people's well-being.

\section{About the IUCN World Heritage Programme}

IUCN is the official advisory body on nature to the UNESCO World Heritage Committee. Working closely with IUCN's Commissions, especially the World Commission on Protected Areas (IUCN-WCPA) and the Species Survival Commission (IUCN-SSC), IUCN Members and a range of partners, IUCN's World Heritage Programme evaluates new sites nominated to the World Heritage List, monitors the conservation of listed sites, and promotes the World Heritage Convention as a leading global instrument for conservation. The IUCN World Heritage Programme provides support, advice and training to site managers, governments, scientists and local communities.

The IUCN World Heritage Programme also initiates innovative ways to enhance the role of the World Heritage Convention in protecting the planet's biodiversity and natural heritage, and in positioning the worlds' most iconic places as exemplars of nature-based solutions to global challenges.

www.iucn.org/worldheritage worldheritageoutlook.iucn.org 


\section{IUCN World Heritage Outlook 3}

A conservation assessment of all natural World Heritage sites

November 2020 
The designation of geographical entities in this book, and the presentation of the material, do not imply the expression of any opinion whatsoever on the part of IUCN or other participating organisations concerning the legal status of any country, territory, or area, or of its authorities, or concerning the delimitation of its frontiers or boundaries.

The views expressed in this publication do not necessarily reflect those of IUCN or other participating organisations.

IUCN is pleased to acknowledge the support of its Framework Partners who provide core funding: Ministry for Foreign Affairs of Finland; Government of France and the French Development Agency (AFD); the Ministry of Environment, Republic of Korea; the Norwegian Agency for Development Cooperation (Norad); the Swedish International Development Cooperation Agency (Sida); the Swiss Agency for Development and Cooperation (SDC) and the United States Department of State.

This publication has been made possible by funding from the MAVA Foundation.

Published by: $\quad$ IUCN, Gland, Switzerland

Copyright: $\quad$ (c) 2020 IUCN, International Union for Conservation of Nature and Natural Resources

Reproduction of this publication for educational or other non-commercial purposes is authorised without prior written permission from the copyright holder provided the source is fully acknowledged.

Reproduction of this publication for resale or other commercial purposes is prohibited without prior written permission of the copyright holder.

Citation: $\quad$ Osipova, E., Emslie-Smith, M., Osti, M., Murai, M., Åberg, U., Shadie, P. (2020). IUCN World Heritage Outlook 3: A conservation assessment of all natural World Heritage sites, November 2020. Gland, Switzerland: IUCN. x + 90pp.

ISBN: $\quad$ 978-2-8317-2085-2 (PDF)

978-2-8317-2086-9 (print)

DOI: $\quad$ https://doi.org/10.2305/UCN.CH.2020.16.en

Cover photo: C Frans Lanting/National Geographic Creative

Layout by: $\quad$ Guilder Design, Dublin, Ireland (www.guilderdesign.com)

Printed by: $\quad$ Langham Press

Available from: $\quad$ IUCN, International Union for Conservation of Nature

World Heritage Progamme

Rue Mauverney 28

1196 Gland, Switzerland

worldheritageoutlook.iucn.org

worldheritageoutlook@iucn.org

www.iucn.org/resources/publications

The text of this book is printed on paper made from wood fibre from well-managed forests certified in accordance with the rules of the Forest Stewardship Council (FSC). 


\section{Contents}

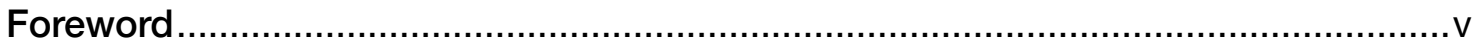

Executive summary ...................................................................................... vii

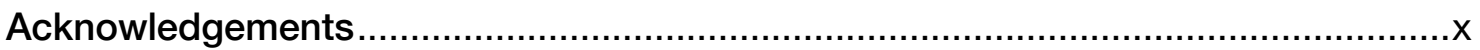

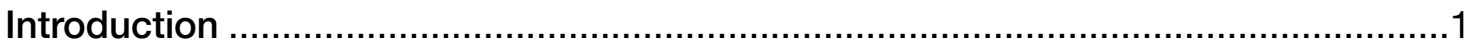

Methodology

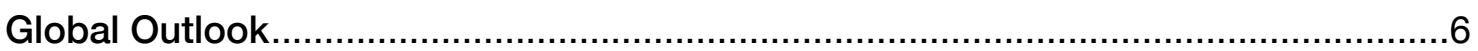

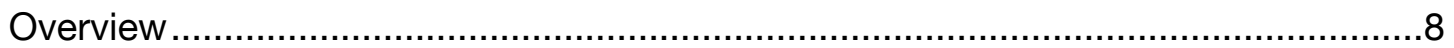

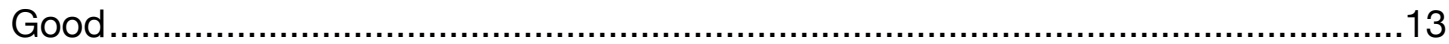

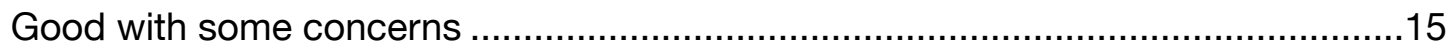

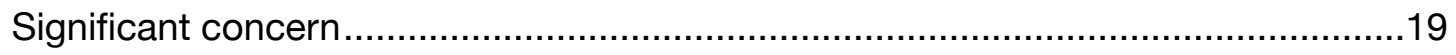

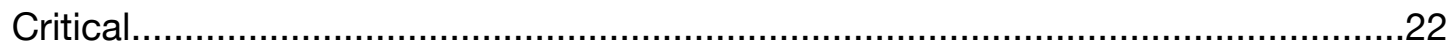

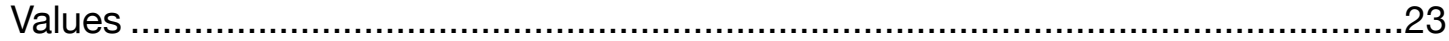

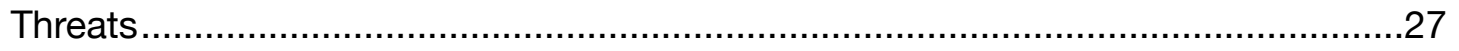

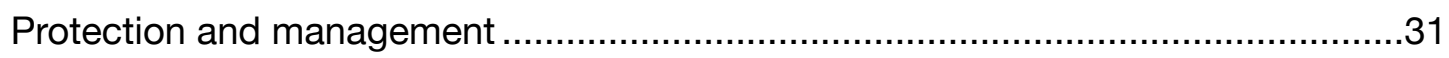

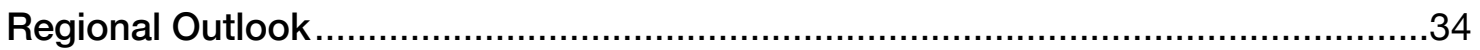

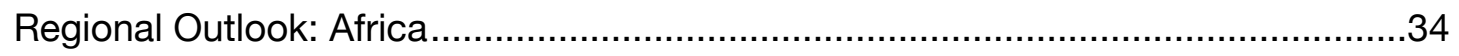

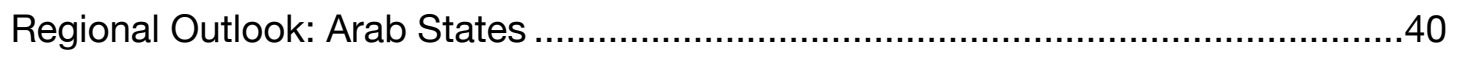

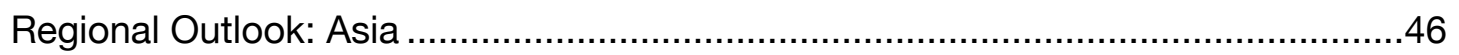

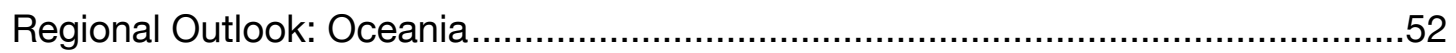

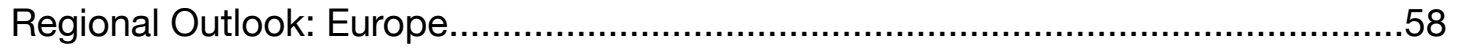

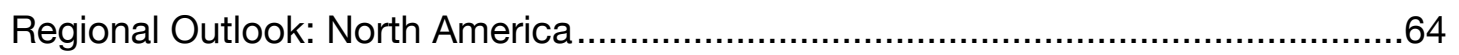

Regional Outlook: Mesoamerica and the Caribbean...............................................70

Regional Outlook: South America ......................................................................

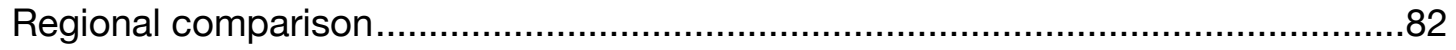

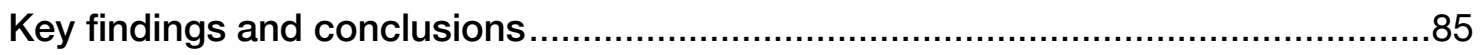

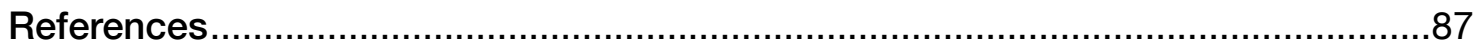

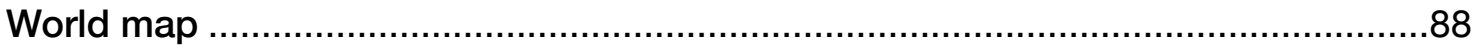

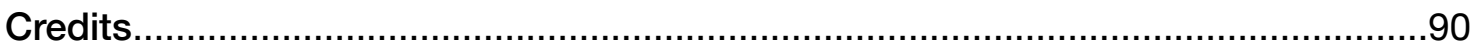





\section{Foreword}

The year 2020 should be remembered as a tipping point in the history of humankind. A time when our ability to act collectively in the face of uncertainty has been tested to its limits and when, confronted with tragedy, we transformed our lives to protect each other, often at great cost. In the midst of the COVID-19 pandemic, we must look to a brighter future, a future where we stand together and work as one for the common good.

This testing time comes as the international community determines a new course of action to preserve the diversity of life on Earth through the Post-2020 Global Biodiversity Framework. Led by the UN's Convention on Biological Diversity, we are taking stock of progress towards the Aichi Targets set in 2010, and agreeing new targets and indicators for the next decade and beyond. The World Heritage Convention, created in 1972 and with 194 signatories, can shape this process. The Convention embodies our ambition to pass the planet's most precious places undamaged from one generation to the next. Understanding our ability to honour these commitments will surely be the ultimate test for our vision of "Living in Harmony with Nature" by 2050.

The IUCN World Heritage Outlook assesses the conservation prospects of all natural World Heritage sites: designated as such because they harbour irreplaceable ecosystems and provide habitats critical to the survival of globally threatened species. Examining the successes and challenges of preserving these places is an indicator of what is happening to biodiversity more broadly. IUCN's assessment shows whether current conservation measures are sufficient, if more must be done, and where.

The conclusions of IUCN World Heritage Outlook 3 are somewhat sobering. Climate change is now the most prevalent threat to natural World Heritage sites and the harm caused to these sites by the pandemic's disruption is becoming clear. Since the previous assessment in 2017, more sites have deteriorated than have improved and, whilst we should celebrate the successes, the threats sites face are escalating. There is much work to be done to secure the conservation in perpetuity of them all.

The great wealth of information brought together for IUCN World Heritage Outlook 3, and the expertise needed to interpret it, are testimony to IUCN's unique ability to mobilise its Members, partners and Commission experts. The report is the work of hundreds, including many from IUCN's World Commission on Protected Areas and Species Survival Commission. The sites they have assessed are celebrated as places so valuable that they transcend national boundaries, cultures and generations. In these uncertain times, we hope everyone can look to these aweinspiring places as proof of our collective commitment to conserving life on Earth.

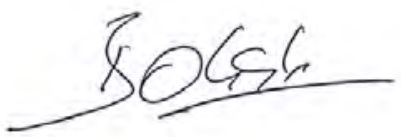

Bruno Oberle

Director General, IUCN

\section{Katreen Mackinnow}

Kathy MacKinnon,

Chair,

UCN World Commission on Protected Areas

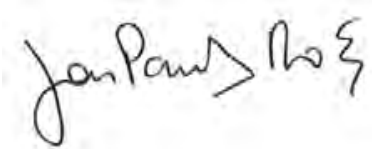

Jon Paul Rodriguez

Chair,

UCN Species Survival Commission 



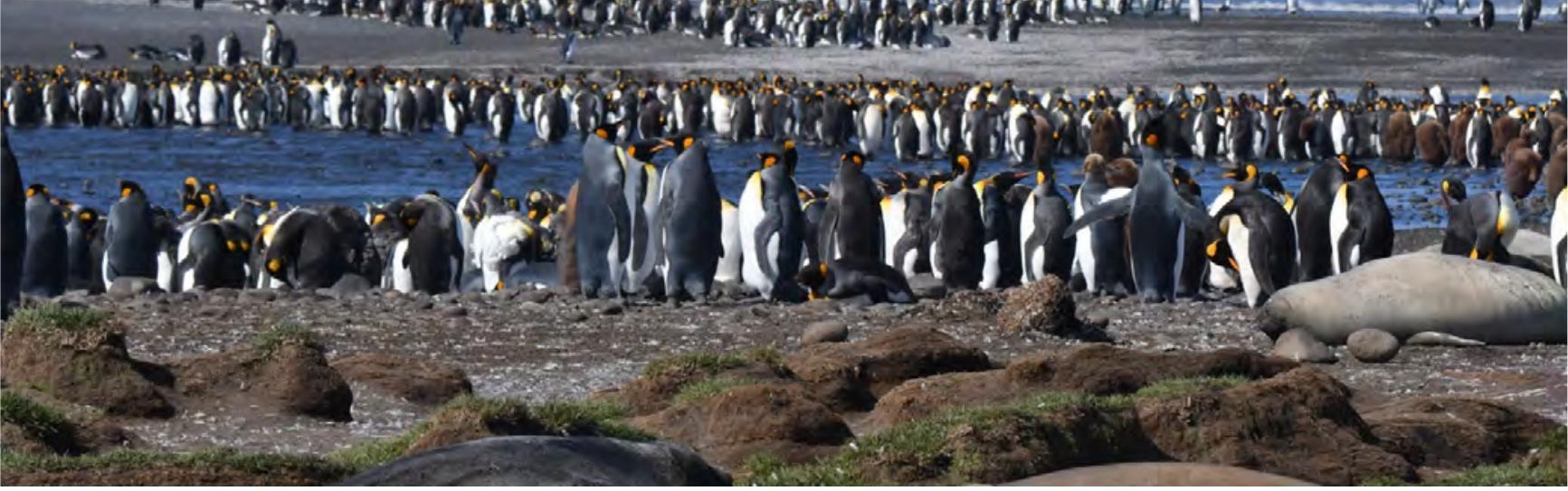

\section{Executive summary}

This report, IUCN World Heritage Outlook 3, builds on three cycles of Conservation Outlook Assessments undertaken since 2014. It presents the main results for 2020, but also some longer-term trends based on a comparison of three data sets now available. As such, it can serve as an indicator of the effectiveness of protected and conserved areas at a time when the international community seeks to measure progress towards global biodiversity targets and defines the Post-2020 Global Biodiversity Framework.

Focusing on the natural values for which sites are inscribed, threats to these values, and the effectiveness of actions to protect them, the IUCN World Heritage Outlook assesses the conservation prospects of all natural World Heritage sites. These sites are globally recognised as the most significant natural areas on Earth and their conservation must meet the high standards of the World Heritage Convention. Our ability to conserve these sites is thus a litmus test for the broader success of conservation worldwide. Securing a positive outlook for these sites is a priority, as expressed in the Promise of Sydney carried by IUCN's World Parks Congress in 2014.

The IUCN World Heritage Outlook includes two equally-important components: a website (worldheritageoutlook.iucn.org) providing detailed assessments for each site, and a regular report - which we present here - summarising global and regional results. Key findings of the IUCN World Heritage Outlook 3 are presented below. Readers are encouraged to explore online assessments to discover the depth of information and many stories of conservation on the ground.

\section{Since 2017 more sites deteriorated than improved}

A comparison between 2017 and 2020 shows that a total of 24 sites changed their overall conservation outlook, with 16 deteriorating and only 8 improving. This is a marked shift in the pattern from 2017, when almost equal numbers of sites either improved (14) or deteriorated (12) compared to 2014. Worryingly, two sites have entered the critical category since 2017: the Great Barrier Reef (Australia) and the Islands and Protected Areas of the Gulf of California (Mexico).

When considering changes over the three assessments cycles since 2014, approximately $17 \%$ of all natural sites changed their conservation outlook at least once. Of these less than half showed improvements. For a few sites, the trends have fluctuated in either direction, as their conservation outlook changed both between 2014 and 2017, and between 2017 and 2020. 


\section{Threats to natural World Heritage sites continue to increase}

The IUCN World Heritage Outlook assesses both current threats where impact is already visible, and potential threats which could affect a site in the future, using a standard classification of threat categories. The 2020 results show that almost all categories of threats are occurring in an increasing number of natural World Heritage sites.

\section{Climate change tops the list of threats}

Climate change continues to affect more and more natural World Heritage sites. In 2014, the IUCN World Heritage Outlook identified climate change as the most significant potential threat and in 2017, it became the fastest growing threat. In 2020, climate change has become the most prevalent current threat. Overall, it is assessed as a high or a very high threat in 83 out of 252 sites. Climate change also still remains by far the largest potential threat.

The manifold impacts of climate change - increasing frequency and severity of fires, coral bleaching, damage from severe weather events, droughts, to name a few - are often accompanied by other threats. For some sites, such combination of threats has resulted in a deteriorated conservation outlook.

\section{Invasive alien species and tourism impacts follow climate}

Invasive alien species, which was assessed as the most common threat both in 2014 and 2017, follows closely behind climate change as the second most common current threat in 2020. It is followed by impacts from a range of threats derived from human activities: tourism visitation, hunting, fishing, fires and livestock grazing.

\section{The top three current threats are not the same in each region}

While the top three current threats globally have remained the same as in 2017, significant regional differences were observed in 2020. Direct resource use (hunting and/or fishing) is becoming one of the most prevalent high or very high threats in Africa, Asia and Mesoamerica and the Caribbean. Solid waste has moved up to the top three most prevalent current threats in the Arab States, which is particularly associated with plastic pollution of marine areas. In South America livestock grazing moved up to the top three most common threats. The drivers of these threats to World Heritage are different in different regions and call for a more bespoke approach to threat abatement and mitigation.

\section{The effectiveness of protection and management remains of concern}

The 2020 results for all 252 natural World Heritage sites show that just 50\% of sites have effective or highly effective protection and management overall. When comparing the 228 sites, for which three data sets are now available, this represents a slight improvement since 2017 (48\%). The percentage of sites with overall effective management has increased in Europe, Asia, South America and the Arab States when compared to 2017.

However, it is alarming that absolutely critical aspects of protection and management, such as sustainable financing, effective enforcement, staffing, and general management effectiveness consistently show as of serious concern. Sustainable finance emerged as the most recurring issue rated as of serious concern in 2017 and it remains so in 2020. This signals that much more commitment is needed to adequately resource the protection and management of the world's most precious and irreplaceable places - never more important than in a climate of increasing threats. 


\section{The overall outlook for natural World Heritage sites is not improving}

The global World Heritage Outlook in 2020 remains similar to that in 2017 and 2014 with a positive conservation outlook ("good" or "good with some concerns") for only 63\% of sites, an outlook of "significant concern" for 30\% and a "critical" status for 7\%. These results are for the 252 natural and mixed (both cultural and natural) World Heritage sites listed as of November 2020, including 11 sites inscribed on the World Heritage List since the last report. While individual conservation successes have happened in a number of sites, overall this picture shows that much more is required to meet the ambition of improving conservation outlook for all natural World Heritage.

When comparing results for the 228 sites inscribed on the World Heritage List up to 2014, for which comparisons between three assessments can now be made, we see that the number of sites whose conservation outlook is assessed as "good" continues to decrease (from 47 to 43 to 40 in 2014, 2017 and 2020, respectively). While this represents a fraction of all sites, it is detecting a concerning trajectory: even the most pristine, and in many cases well-managed, natural sites are facing threats, either from climate change or increasing development pressures in their broader surroundings.

\section{The COVID-19 pandemic causes revenue loss and increased risk of poaching}

A picture is emerging of the initial impacts on sites from the Coronavirus disease (COVID-19) pandemic. The IUCN World Heritage Outlook 3 assessment cycle started before COVID-19 became globally widespread, so the issue could not be recorded systematically for all sites. Nevertheless, more than 50 sites have recorded actual or potential impacts from COVID-19 to date.

Some assessments note positive aspects stemming from the pandemic, most notably a decrease in pressure from tourism visitation on natural ecosystems. However, negative factors are numerous. The closing of sites to tourism causes significant loss of revenue and livelihoods. Limits to in-person staffing leads to reduced control over illegal activities. These factors are increasing the risk of wildlife poaching and illegal use of natural resources, with incidents recorded in some sites since the pandemic.

\section{Positive examples show that conservation works}

There is still a majority of sites assessed with a positive conservation outlook (47 "good" and 112 "good with some concerns"). These sites provide examples of best practice, demonstrating the potential of World Heritage sites in addressing complex challenges. The many stories of determination and success happening on the ground are detailed in the 252 Conservation Outlook Assessments available online on worldheritageoutlook. iucn. org. 


\section{Acknowledgements}

The IUCN World Heritage Outlook is underpinned by the knowledge and expertise of hundreds of experts and organisations, without whom this report, and the assessments on which it is based, would not have been possible. We are extremely grateful for the in-depth work of the many hundreds of assessors and reviewers who have contributed to this report.

Input to the IUCN World Heritage Outlook draws widely from across IUCN's networks, including members of IUCN's World Commission on Protected Areas (WCPA), the IUCN Species Survival Commission (SSC), IUCN Member organisations, IUCN regional and country offices, as well as a vast array of other stakeholders involved in the conservation and management of natural World Heritage sites. IUCN is particularly grateful to all site managers who provided inputs and information that helped update assessments.

We give special thanks to IUCN World Heritage Outlook Partners - currently the African Wildlife Foundation (AWF), BirdLife International, Canadian Parks and Wilderness Society (CPAWS), Fauna and Flora International (FFI), Frankfurt Zoological Society (FZS), Wildlife Conservation Society (WCS), World Heritage Watch, WWF, and the Zoological Society of London (ZSL) - who have committed to addressing the conservation issues in natural World Heritage sites. We encourage other governmental, non-governmental bodies and the private sector to follow their lead in helping to assure the long-term protection of the planet's priceless natural World Heritage.

We also thank our colleagues in the UNESCO World Heritage Centre, ICOMOS and ICCROM for their collaboration in the preparation of State of Conservation documentation for the World Heritage Committee, which provides an invaluable information base for many sites that are discussed in this report.

We thank the following individuals who have provided advice and expertise on shaping the IUCN World Heritage Outlook methodology over the last six years: Tim Badman, Patricia Cremona, Jon Day, Naomi Doak, Craig HiltonTaylor, Ackbar Joolia, Susanna Lindeman, Geoffroy Mauvais, Steffen Oppel, Scott Perkin, Peter Shadie, Kevin Smith, Andrej Sovinc and Sue Stolton. We thank the members of the IUCN Regional Review Groups, as well as the IUCN World Heritage Panel who have been instrumental in ensuring quality and consistency across all assessments. We also thank the reviewers of this report, Cyril Kormos and Thierry Lefebvre, and substantive editor, Bastian Bertzky, for bringing their respective expertise and oversight to this report.

IUCN thanks the members of the IUCN World Heritage Programme for their work in drawing together the Conservation Outlook Assessments, Ulrika Åberg, Jean-Baptiste Bosson, Matthew Emslie-Smith, Mizuki Murai and Katherine Zischka. We thank Célia Zwahlen for communications expertise in copy editing this report, and Matea Osti for leading the technical development of the IUCN World Heritage Outlook system, in coordination with our partner Eau de Web, whose support allowed the hundreds of assessors, reviewers and other contributors to complete the Conservation Outlook Assessments effectively online.

IUCN gives special mention and thanks to Elena Osipova, IUCN World Heritage Outlook Coordinator, whose commitment and skill in managing each and every element of this 2020 Outlook assessment process is sincerely appreciated.

Finally, IUCN acknowledges with sincere thanks the MAVA Foundation, who have engaged consistently with IUCN in pioneering new approaches to our work supporting World Heritage conservation, and whose generous financial support has made the IUCN World Heritage Outlook possible. 


\section{Introduction}

Given their high profile and visibility on the international stage, natural World Heritage sites provide a window into the successes and challenges on the frontlines of conservation. Monitoring them is therefore an extremely important barometer of the effectiveness of the global community's overall effort to address conservation challenges. The World Heritage Convention includes such monitoring mechanisms, which the IUCN World Heritage Outlook complements in a unique way by assessing all natural World Heritage sites together at a given point in time - first in 2014, then 2017, and now 2020.

With three sets of data over a six-year period now available (IUCN, 2020), this report, IUCN World Heritage Outlook 3 , provides an opportunity to identify evolving trends in the global status of natural World Heritage. As such, it can be used as a metric to track progress towards achieving better conservation outcomes for natural World Heritage sites over time. Results from the IUCN World Heritage Outlook are already contributing to action on the ground and improved conservation outcomes. It is IUCN's hope that these assessments continue to drive specific actions on the ground to conserve the critical values of natural World Heritage sites, and optimise their contribution to human well-being.

While the COVID-19 pandemic has sent shock waves around the world, the foundations sustaining life on Earth remain in peril. The state of the planet's life support systems has been chronicled in several landmark high-level reports since the last update of the IUCN World Heritage Outlook in 2017. These include assessments from the Intergovernmental Panel on Climate Change (IPCC), Intergovernmental Science-Policy Platform on Biodiversity and Ecosystem Services (IPBES), and the fifth edition of the Global Biodiversity Outlook by the Convention on Biological Diversity (CBD), to name a few. These reports all show that we face an unprecedented global environmental crisis that is accelerating fast and calls for urgent, collective and transformative action.

The World Heritage Convention is uniquely placed to meet this challenge by protecting those places that have high biodiversity, functional habitats and high ecosystem integrity. World Heritage, with its powerful influence, can therefore play a decisive role in protecting nature and can be pivotal in climate change mitigation and adaptation.

\section{Protecting the priceless}

World Heritage sites are internationally recognised areas of Outstanding Universal Value (OUV) - places so valuable that the importance of their conservation transcends boundaries, cultures and generations. These exceptional places - 1,121 in total at the time of writing - shape humanity's collective sense of identity and belonging; they inspire hope and replenishment even in the most trying times, like those we have been experiencing with the COVID-19 pandemic.

Natural World Heritage sites are celebrated as the most significant protected areas on Earth, boasting large intact land and seascapes. There are 252 natural sites inscribed as of the date of publication of this report, including 39 sites classified as "mixed" (natural and cultural), which hereafter we refer together simply as natural World Heritage sites. While the number of these sites is relatively small, they cover over 369 million hectares of land and sea, an area larger than the size of India. Their coverage represents about $8 \%$ of the total area covered by more than 259,000 protected areas globally.

These are areas of stunning natural beauty, places which harbour unique and endangered species and teach us about Earth's history: the healthy ecosystems of the Okavango Delta (Botswana) or the Central Amazon Conservation Complex (Brazil) and their rich biodiversity; traces of the past in Wadi Al-Hitan (Egypt); huge areas of land, such as Qinghai Hoh Xil (China), or of sea, like in the French Austral Lands and Seas (France). Each of these areas is special in its own way and provides a unique set of benefits and ecosystem services. Collectively, they make a substantial contribution to global biodiversity conservation, sustainable development, solutions to climate change, and ultimately the quality of life on Earth. 


\section{Objectives}

This report provides an overview of the main conservation issues that natural World Heritage sites are facing, and the trends and changes observed over the last six years. It presents an inventory of sites under each category - good, good with some concerns, significant concern and critical - and reveals global results on sites' state of natural values, threats and protection and management. Finally, it breaks down the results across different regions of the world.

Beyond the global and regional trends presented in this report, each individual Conservation Outlook Assessment, accessible at worldheritageoutlook.iucn.org, provides a unique insight into the challenges, opportunities, successes and benefits of conserving these special places.

The main objectives of the IUCN World Heritage Outlook are to:

- Track the state of conservation of all natural World Heritage sites over time and raise awareness of their importance for biodiversity conservation.

- Recognise well-managed sites for their conservation efforts and encourage the transfer of good management practices between sites.

- Identify the most pressing conservation issues affecting natural World Heritage sites and the actions needed to remedy those issues, thereby informing the international community, including IUCN, its Members and partners.

- Understand and communicate the benefits of World Heritage sites for local and global communities, for example in providing livelihoods and sustaining healthy ecosystems, at a time of fast-moving environmental, economic and humanitarian crises. 


\section{Methodology}

The IUCN World Heritage Outlook is unique in its assessment of all natural World Heritage sites simultaneously, every three years. It is thus the only global assessment of natural World Heritage taken at a single point in time. As mentioned above, by natural World Heritage sites we mean both natural and mixed (natural and cultural) sites. While components of the methodology have evolved with each subsequent cycle, the underlying assessment framework has remained the same since 2014 (IUCN, 2020a), thereby allowing for consistency and comparability of data between cycles.

Much more than a report, the IUCN World Heritage Outlook consists of individual Conservation Outlook Assessments prepared for each natural World Heritage site (IUCN, 2020), available online at worldheritageoutlook.iluch.org. The Conservation Outlook Assessments provide a projection of whether a site is likely to conserve its World Heritage values over time based on the assessment of:

- The current state and trend of values

- The threats affecting those values

- The effectiveness of protection and management

Based on the assessment of these key elements, the overall conservation outlook for a particular site is assessed against four rating categories. Where insufficient data is available to draw a conclusion, a site may be categorised as "data deficient". The Conservation Outlook Assessments also compile additional information on the specific benefits that each site provides, and on active projects in and around the site; however, this data does not influence the rating.

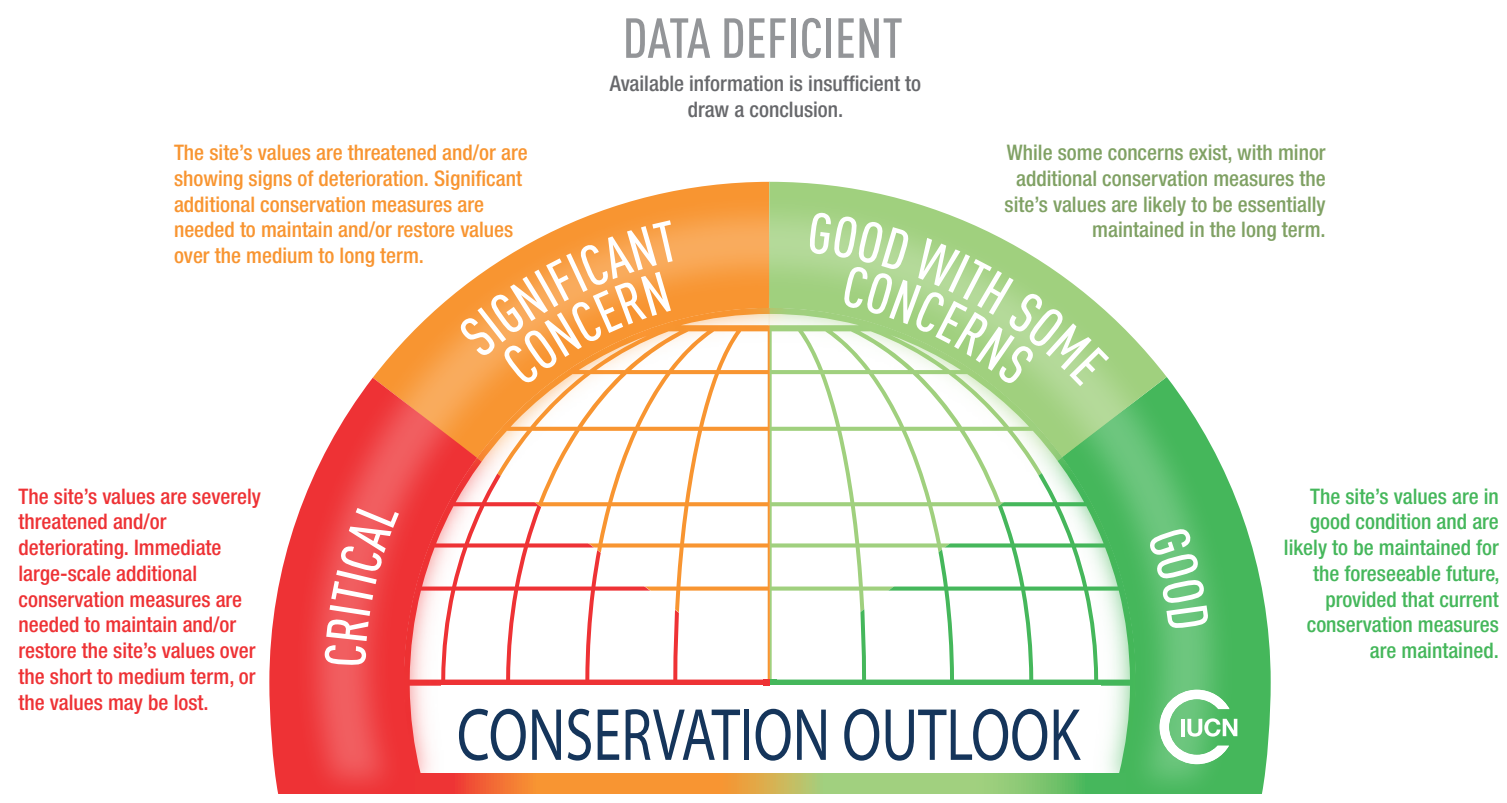


The standardised methodology for the Conservation Outlook Assessments was developed by IUCN in 2011 by an IUCN-led technical advisory group. The methodology draws on a wide range of existing methodologies for protected area assessments, including:

- Methodologies and frameworks for management effectiveness of protected areas, developed by IUCN's World Commission on Protected Areas (Hockings et al., 2006)

- Lessons learned from the assessment framework developed for the Great Barrier Reef Outlook report (Great Barrier Reef Marine Park Authority, 2009)

- The Enhancing Our Heritage Toolkit (Hockings et al., 2008)

- The Managing Natural World Heritage Manual (Stolton et al., 2012)

- The World Heritage Periodic Reporting questionnaire (Cycles II and III) (UNESCO, 2008; 2018)

Following the 2017 assessment cycle, the methodology was further refined by IUCN based on feedback collected during the assessment cycle. Some threat categories have been simplified (e.g. "hunting (commercial/subsistence)" and "poaching" fields from 2017 have been combined into one "hunting and trapping" category), while a new function to distinguish between legal and illegal activities has been introduced for biological resource use types (hunting and trapping, fishing, logging). Some threats can now also be reported at the species level (e.g. invasive alien species, or those targeted by biological resource use). This adaptive approach to the methodology is intended to enable the improvement of the IUCN World Heritage Outlook methodology over time, but in a manner that ensures assessments are consistent and comparable between cycles.

All Conservation Outlook Assessments are desk-based and no new site visits are undertaken. The assessments are completed by experts based on their own knowledge of a site and on information from sources including, but not limited to: IUCN's knowledge base on natural World Heritage sites; official and publicly available documents on the UNESCO World Heritage Centre's website (such as State of Conservation reports, mission reports etc.); existing management effectiveness evaluations and other relevant management documents; scientific articles; and information gathered through consultation with a wide range of knowledgeholders, including site managers and management authorities.

Each type of information source has its different strengths and limitations in terms of depth, coverage and quality. Assessments help identify information gaps which, if filled, will aid future assessments. The source information for each Conservation Outlook Assessment is listed on the IUCN World Heritage Outlook website.

The Conservation Outlook Assessments undertaken in 2014 established a baseline for monitoring the conservation outlook of sites over time, with the 2017 update providing the first opportunity for comparison. The 2020 update represents the second update of assessments, and allows for the identification of longerterm trends and changes in the conservation outlook of natural World Heritage sites since 2014. This report focuses predominantly on recent changes (i.e. between 2017 and 2020); however, an overview of global trends since 2014 is provided for values, threats, protection and management, and overall conservation outlook of sites.

\section{Consultation process}

The consultation process is indispensable to the IUCN World Heritage Outlook to ensure that Conservation Outlook Assessments are as accurate as possible, up to date and focused on the most pressing issues.

All assessments are publicly available online on worldheritageoutlook.iucn.org and comments are welcome at any time through an online feedback form. Full details of the Conservation Outlook Assessment methodology are also available on the website. 
A range of knowledge-holders are informed and invited to take part in the consultation process. They typically include:

- IUCN Commission members, in particular those of IUCN's World Commission on Protected Areas and Species Survival Commission

- IUCN Secretariat, which is spread across global headquarters, 11 regional offices and more than 50 country offices

- Site managers and stakeholders involved in the management of sites (including IUCN Member organisations, government authorities, non-governmental organisations, community groups, and international agencies)

- Researchers and the scientific community

Each assessment undergoes multiple internal and external reviews before finalisation. Draft assessments, prepared by assessors selected for their knowledge of a site, are first reviewed internally to verify that they meet the required standards. Inputs are then sought from external peer reviewers. Following this, all assessments are reviewed by IUCN's operational regions. These regional review groups consist of the IUCN WCPA Regional Vice-Chairs, representatives of the IUCN regional offices, and regional specialists for World Heritage. A final draft is then prepared for each Conservation Outlook Assessment, incorporating feedback received, and wherever possible site managers are invited to fact check, provide updates and comments, which are then also considered for the final version of the assessment. The IUCN World Heritage Panel, composed of experts specialised in the field of natural World Heritage, provides final approval of all completed assessments.

Main steps in the IUCN World Heritage Outlook consultation process

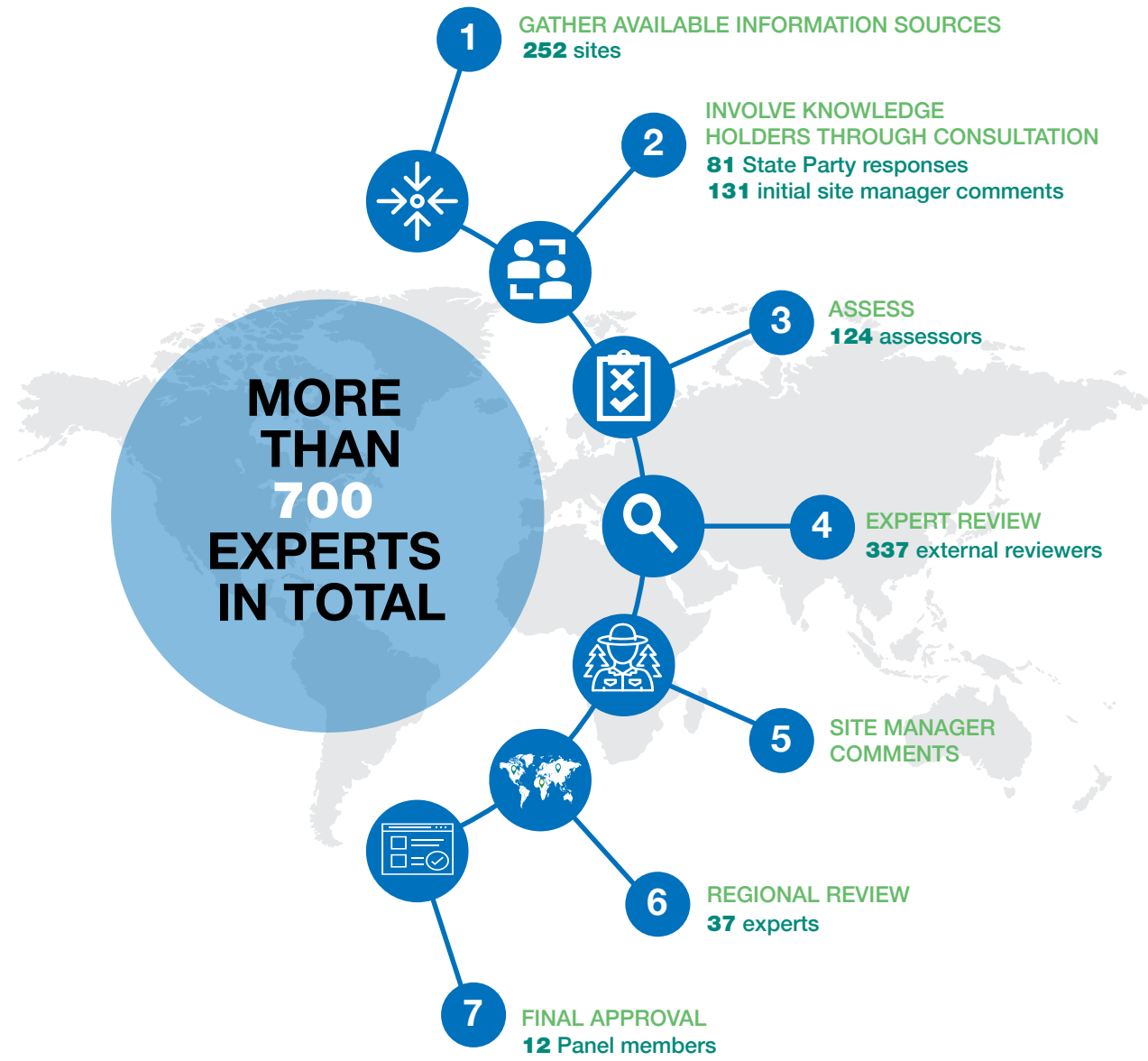



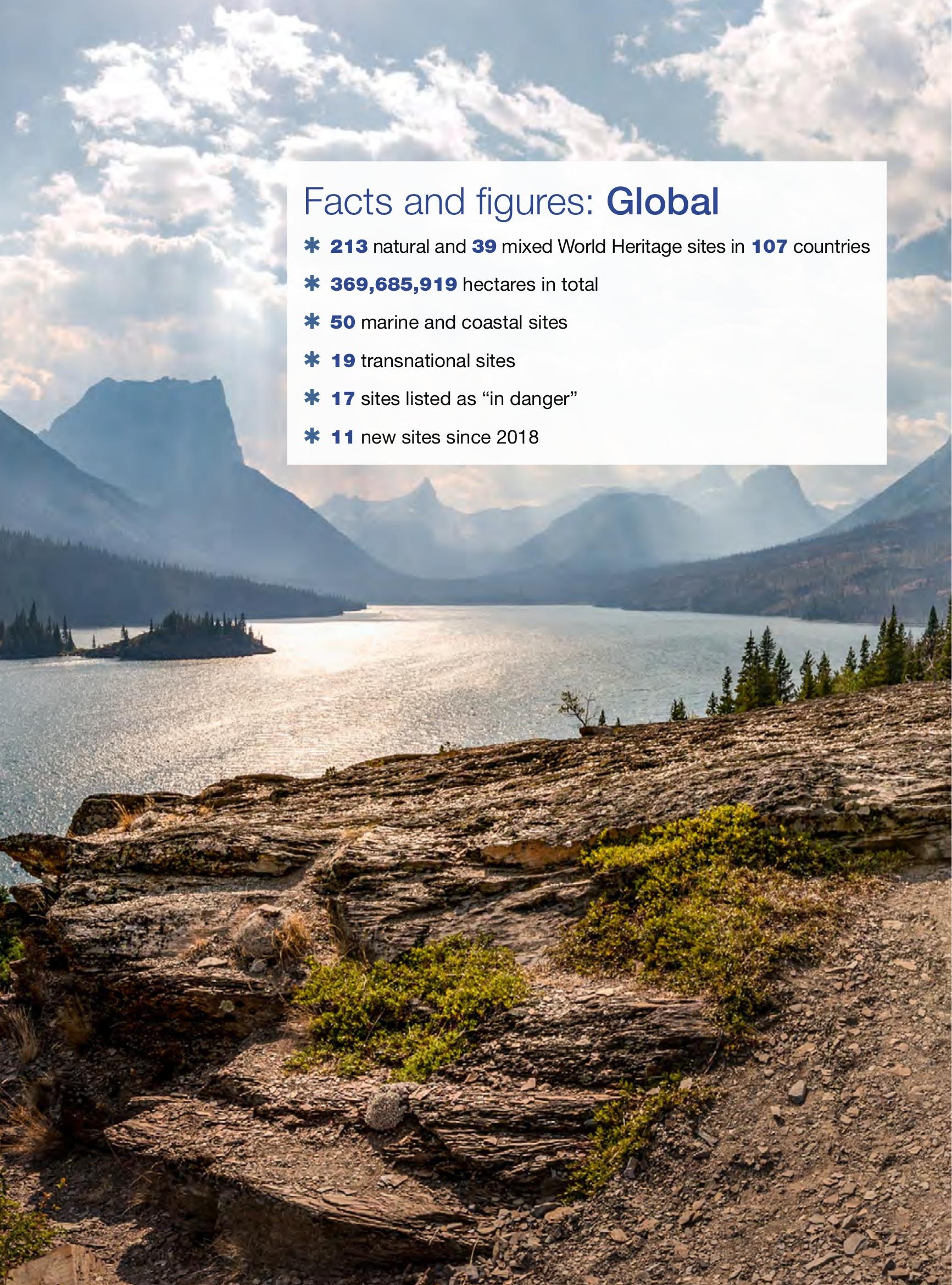


\section{Overview}

The IUCN World Heritage Outlook provides a global assessment of natural World Heritage, based on data from Conservation Outlook Assessments for every natural site on the World Heritage List. In 2014, it provided the first such assessment for the 228 sites, at the time, classified as natural and mixed (natural and cultural). In 2017, the IUCN World Heritage Outlook 2 included Conservation Outlook Assessments for 241 sites, and since then another 11 sites from nine countries have been inscribed on the World Heritage List, bringing the current total number of natural and mixed sites to 252.

This chapter presents the main findings from the 2020 Conservation Outlook Assessments, providing the overall results for all 252 natural sites currently listed, and a comparison of results for the 228 sites for which there are now three sets of assessments available (2014, 2017 and 2020).

\section{Overall results}

The results of the IUCN World Heritage Outlook 3 indicate that for $63 \%{ }^{1}$ of all sites (159) the conservation outlook is either "good" or "good with some concerns", while for 30\% (75 sites) the outlook is of "significant concern", and for $7 \%$ (18 sites) it is assessed as "critical".

Figure 1. Conservation outlook 2020 for all 252 natural World Heritage sites

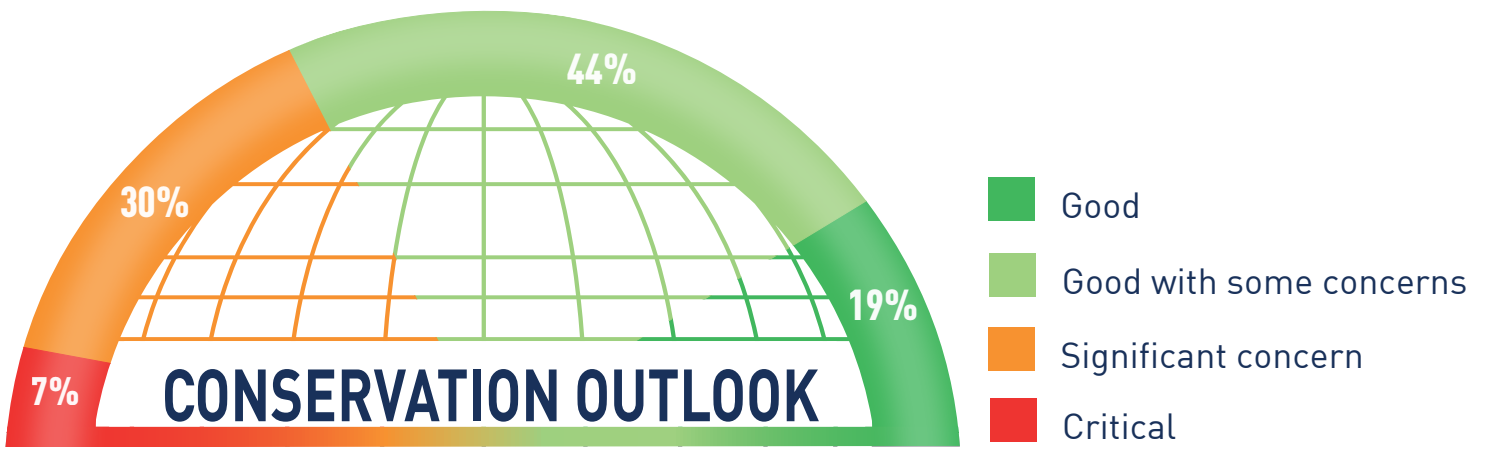

The conservation outlook for natural World Heritage sites in 2020 is similar to the overall results in 2017, with a 1\% decrease in sites assessed as either "good" or "good with some concerns" between 2017 and 2020. It shows that conservation prospects remain positive for almost two-thirds of all natural sites, while also indicating that further significant efforts are required to improve the outlook of many sites.

\section{Results over time}

Looking at the comparative results of the 228 sites for which three sets of data are now available (Figure 2), the conservation outlook of these sites in 2020 remains similar to that of 2017 and 2014, with the exception of a small, but sustained decrease in sites assessed as "good".

A more detailed analysis shows that, for the sites that have followed a trajectory from "good" to "good with some concerns" since 2014 (7 sites), values have deteriorated (from good to low concern), while threats have increased (including in three cases from low to high). However, these threats often originate beyond the sites' boundaries. In Ningaloo Coast and Shark Bay (both in Australia), Swiss Alps Jungfrau-Aletsch (Switzerland) and Papahānaumokuākea (USA), such outside threats are associated with increasing impacts of climate change; in Tsingy de Bemaraha Strict Nature Reserve (Madagascar), Gunung Mulu National Park (Malaysia) and Škocjan Caves (Slovenia), they rather stem from increasing development pressures in the sites' surroundings. 
Figure 2. Conservation outlook of sites in 2014,2017 and 2020, for the 228 sites for which three sets of data are now available

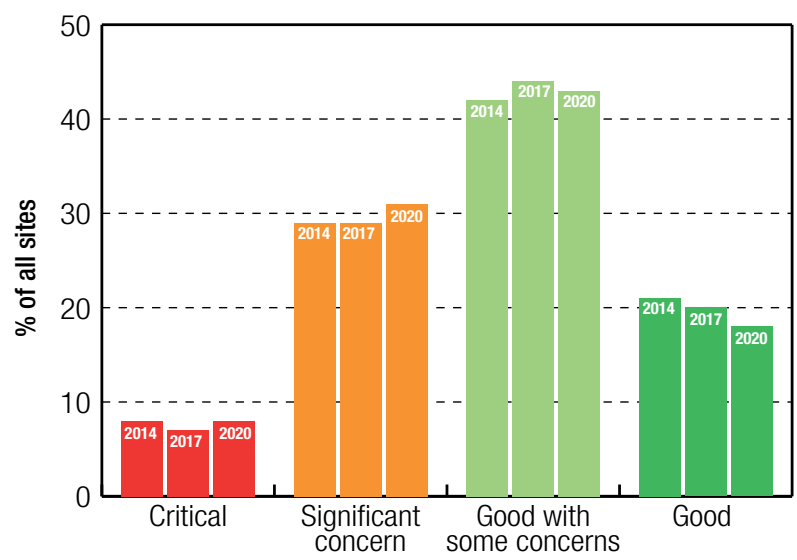

\section{Changes since 2017 assessments}

A comparison between 2017 and 2020 shows that a total of 24 sites changed their overall conservation outlook, with 16 deteriorating and only 8 improving. This is a marked difference from 2017, when almost equal numbers of sites improved or deteriorated: 14 improvements and 12 deteriorations in the overall conservation outlook were observed compared to 2014.

Despite this prevailing negative trend, the cases where the conservation outlook has improved provide important proof that, where concerted conservation action is applied, successful outcomes ensue.

Figure 3. Sites with an improved conservation outlook since 2017

2020

2017

Good

Good with

\section{some}

concerns

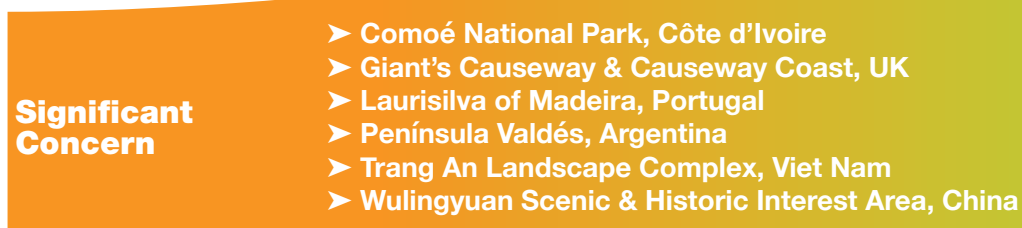

- Laurisilva of Madeira, Portugal

Península Valdés, Argentina

- Wulingyuan Scenic \& Historic Interest Area, China

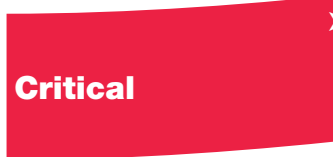

Monarch Butterfly Biosphere Reserve, Mexico 


\section{Wadi Al-Hitan - IUCN Green List at the heart of an improved conservation outlook}

Wadi Al-Hitan (Whale Valley) is a geological World Heritage site in Egypt that demonstrates an iconic evolutionary process in the record of life on Earth: the transition of whales from land-based to ocean-going mammals.

In 2018, the site was listed on the IUCN Green List of Protected and Conserved Areas, a global standard of best practice providing certification for areas that are effectively managed and fairly governed. To be on this list, sites must demonstrate good governance, sound design and planning, effective management, and successful conservation outcomes.

In their assessment of Wadi Al-Hitan, experts of the IUCN Green List noted the site "is managed 'with love' by the staff members, who are qualified, committed and excelling in their work". Efforts invested by these staff and other stakeholders led, among other things, to an updated management plan in 2019 for the wider Wadi El-Rayan Protected Area, in which Wadi Al-Hitan is located. A buffer zone around the World Heritage area has been identified to protect fossilised skeletons from threats (such as visitation and traffic), provide additional safeguards, and facilitate management.

Wadi Al-Hitan's achievement in meeting the IUCN Green List standard helped inform its 2020 Conservation Outlook Assessment. The improvement in these essential elements of the site's management are reflected in the transition of Wadi Al-Hitan's conservation outlook from "good with some concerns" in 2017 to "good" in 2020.

The reasons leading to these positive cases range from better management, decreasing threats, and improved state of values, to a combination of these elements. In Laurisilva of Madeira (Portugal) and Wadi Al-Hitan (Egypt, see text box above), improved management responses to existing threats were decisive factors. Reduced pressure from tourism and infrastructure development projects drove a more positive outlook in the Giant's Causeway and Causeway Coast (UK), Trang An Landscape Complex (Viet Nam) and Wulingyuan Scenic and Historic Interest Area (China). In Península Valdés (Argentina), positive trends in the populations of key species resulting from a decrease in threats, led to an improved rating. Finally in Comoé National Park (Côte d'Ivoire), the conservation outlook continued to improve thanks to a combination of reduced threats and the associated positive ongoing recovery of values.

Between 2014 and 2020, the conservation outlook of 43 sites in total changed at least once. Of these, in 18 cases the conservation outlook improved and in 25 cases it deteriorated. For a few sites the trends have fluctuated in either direction, as their conservation outlook changed both between 2014 and 2017, and between 2017 and 2020. Sites whose conservation outlook first deteriorated, then improved again, indicate the sensitivity of sites to changing threats and management attention, and provide interesting examples of factors of success. In Península Valdés (Argentina), the population of southern right whale, for which the site is a globally significant breeding ground, has been increasing following unusually high levels of whale mortality recorded previously. In Wadi Al-Hitan (Egypt), management significantly improved, which was also recognised by its inclusion on the IUCN Green List of Protected and Conserved Areas in 2018.

A successful case is Comoé National Park (Côte d'Ivoire), which has shown continued improvement across three assessment cycles, improving from "critical" in 2014 to "significant concern" in 2017 and to "good with some concerns" in 2020. 


\section{Comoé National Park}

Comoé National Park was inscribed on the World Heritage List in 1983 under biodiversity criteria (ix) and (x). It covers over one million hectares in north-east Côte d'lvoire, making it one of the largest protected areas in Africa. The landscape is shaped by the Comoé River, which cuts across $270 \mathrm{~km}$ of the site and gives rise to a remarkable variety of transitional habitats, creating unique communities comprised of hundreds of plant and animal species.

In 2017, the IUCN World Heritage Outlook recognised the improved conservation outlook of Comoé National Park as it moved from "critical" to "significant concern", following the site's removal from the List of World Heritage in Danger in 2017. The political situation had stabilised in the country since 2012 and, thanks to international support and increased conservation actions on the ground, it was possible again to resume conservation work and expand the presence of staff on the ground.

This positive trajectory has continued since 2017. While the 2020 Conservation Outlook Assessment of Comoé National Park acknowledges that some threats remain, the site's values have continued to improve as a result of continued conservation efforts. These include increased patrolling, capacity building activities and engagement of local communities in the park's management. The positive impact of such actions is evidenced by the presence of stable populations of chimpanzees, elephants and buffalos, as well as the reported return of some rare bird species that had not been seen for many years.

This continued improvement in the site's values has resulted in its overall more positive conservation outlook, which is now assessed as "good with some concerns".

An example of a variable trend is W-Arly-Pendjari Complex (Benin, Burkina Faso, Niger). Its conservation outlook improved between 2014 and 2017 following the significant transboundary extension of the site, which provided a more robust framework for the conservation of its values across a much larger transboundary area. However, the conservation outlook for this site has since deteriorated again due to increased threats associated with the security situation in the region, and the lack of effective protection and management in a significant portion of the site.

\section{Newly inscribed sites}

Natural sites inscribed on the World Heritage List since the last cycle show mixed results in terms of their conservation outlook, as was the case in 2017. This confirms that even new sites that should, by definition, have met the stringent requirements to warrant World Heritage listing, can face serious concerns including significant threats and ineffective protection and management. This is the case of the Migratory Bird Sanctuaries along the Coast of the Yellow Sea-Bohai Gulf of China (China) inscribed in 2019, when IUCN's recommendation was to defer the inscription pending resolution of a number of issues related to integrity, protection and management. Several significant concerns persist at this site, resulting in a conservation outlook of "significant concern". 
Table 1. Conservation outlook for 11 sites inscribed between 2018 and 2020

\begin{tabular}{|c|c|c|c|c|}
\hline Site & Country & Region & Inscription year & Conservation Outlook 2020 \\
\hline Barberton Makhonjwa Mountains & South Africa & Africa & 2018 & Good with some concerns \\
\hline $\begin{array}{l}\text { Chaîne des Puys - Limagne fault } \\
\text { tectonic arena }\end{array}$ & France & Europe & 2018 & Good with some concerns \\
\hline $\begin{array}{l}\text { Chiribiquete National Park - "The } \\
\text { Maloca of the Jaguar" }\end{array}$ & Colombia & South America & 2018 & Good with some concerns \\
\hline Fanjingshan & China & Asia & 2018 & Good with some concerns \\
\hline French Austral Lands and Seas & France & Europe & 2019 & Good \\
\hline Hyrcanian Forests & Iran & Asia & 2019 & Significant concern \\
\hline $\begin{array}{l}\text { Migratory Bird Sanctuaries along } \\
\text { the Coast of Yellow Sea-Bohai Gulf } \\
\text { of China (Phase I) }\end{array}$ & China & Asia & 2019 & Significant concern \\
\hline $\begin{array}{l}\text { Paraty and Ilha Grande - Culture } \\
\text { and Biodiversity }\end{array}$ & Brazil & South America & 2019 & Good with some concerns \\
\hline Pimachiowin Aki & Canada & North America & 2018 & Good \\
\hline $\begin{array}{l}\text { Tehuacán-Cuicatlán Valley: } \\
\text { originary habitat of Mesoamerica }\end{array}$ & Mexico & $\begin{array}{l}\text { Mesoamerica and } \\
\text { the Caribbean }\end{array}$ & 2018 & Good with some concerns \\
\hline $\begin{array}{l}\text { Vatnajökull National Park - } \\
\text { Dynamic Nature of Fire and Ice }\end{array}$ & Iceland & Europe & 2019 & Good \\
\hline
\end{tabular}

The following sections include an overview of sites in each of the overall conservation outlook categories ("good", "good with some concerns", "significant concern" and "critical"). Each of these categories not only shows the potential for a site to preserve its values, but also indicates the urgency of measures that need to be taken in order to improve the conservation outlook and ensure long-term conservation of all sites. 


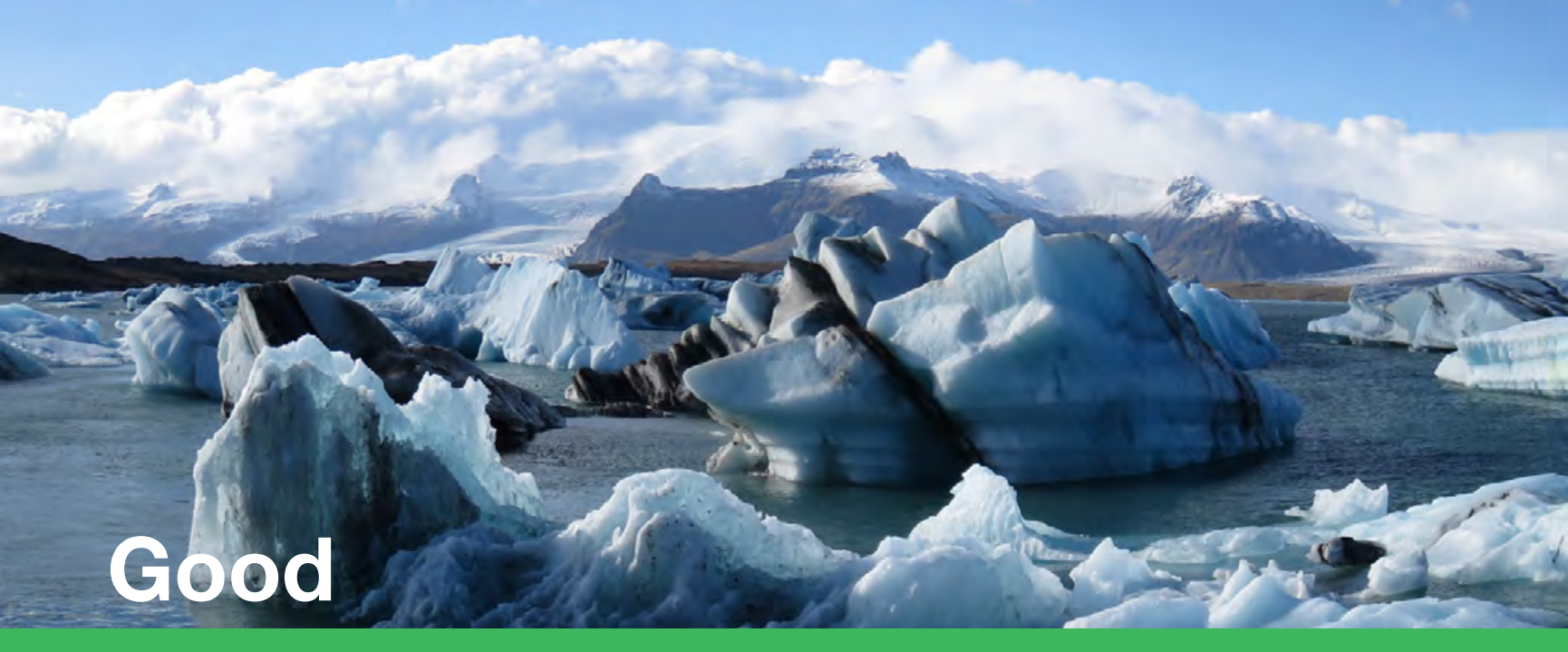

If a site has a "good" conservation outlook, it indicates that its values are currently in good condition and are likely to be maintained for the foreseeable future, provided that current conservation measures are maintained. Some threats to the site's values might exist and it is therefore essential that effective management efforts are maintained in order to ensure the site's conservation in the long term. It is important that World Heritage sites with a good outlook maintain their current performance, and serve as examples of good management practices. The IUCN World Heritage Outlook 3 assesses the following 47 sites to have a good conservation outlook:

\begin{tabular}{ll} 
Country & Site \\
\hline Australia & Australian Fossil Mammal Sites (Riversleigh / Naracoorte) \\
\hline Hungary, Slovakia & Caves of Aggtelek Karst and Slovak Karst \\
\hline China & Chengjiang Fossil Site \\
\hline China & China Danxia \\
\hline Canada & Dinosaur Provincial Park \\
\hline UK & Dorset and East Devon Coast \\
\hline France & French Austral Lands and Seas \\
\hline USA & Hawaii Volcanoes National Park \\
\hline Australia & Heard and McDonald Islands \\
\hline Finland, Sweden & High Coast / Kvarken Archipelago \\
\hline Argentina & Ischigualasto-Talampaya Natural Parks \\
\hline Republic of Korea & Jeju Volcanic Island and Lava Tubes \\
\hline Canada & Joggins Fossil Cliffs \\
\hline India & Khangchendzonga National Park \\
\hline Chad & Lakes of Ounianga \\
\hline Sweden & Laponian Area \\
\hline Russian Federation & Lena Pillars Nature Park \\
\hline Australia & Lord Howe Island Group \\
\hline Argentina & Los Alerces National Park \\
\hline Iran & Lut Desert \\
\hline Germany & Messel Pit Fossil Site \\
\hline Canada & Miguasha National Park \\
\hline Canada & Mistaken Point \\
\hline Italy, Switzerland & Monte San Giorgio \\
\hline China & Mount Emei Scenic Area, including Leshan Giant Buddha Scenic Area \\
\hline Italy & Mount Etna \\
\hline Philippines & Mount Hamiguitan Range Wildlife Sanctuary \\
\hline China & Mount Huangshan \\
\hline
\end{tabular}




\begin{tabular}{ll} 
Country & Site \\
\hline China & Mount Sanqingshan National Park \\
\hline Namibia & Namib Sand Sea \\
\hline New Zealand & New Zealand Sub-Antarctic Islands \\
\hline Canada & Pimachiowin Aki \\
\hline Australia & Purnululu National Park \\
\hline Russian Federation & Putorana Plateau \\
\hline Japan & Shirakami-Sanchi \\
\hline UK & St Kilda \\
\hline Denmark & Stevns Klint \\
\hline Iceland & Surtsey \\
\hline Switzerland & Swiss Tectonic Arena Sardona \\
\hline Spain & Teide National Park \\
\hline New Zealand & Tongariro National Park \\
\hline Australia & Uluru-Kata Tjuta National Park \\
\hline Iceland & Vatnajökull National Park - Dynamic Nature of Fire and Ice \\
\hline Denmark, Germany, Netherlands & Wadden Sea \\
\hline Egypt & Wadi Al-Hitan (Whale Valley) \\
\hline Norway & West Norwegian Fjords - Geirangerfjord and Nærøyfjord \\
\hline Australia & Willandra Lakes Region \\
\hline
\end{tabular}

A The conservation outlook improved since 2017

The conservation outlook deteriorated since 2017

* New site inscribed on the World Heritage List since 2018

Sites with an improved conservation outlook since $2017^{\star}$

\begin{tabular}{|c|c|c|c|c|c|c|}
\hline Site & Country & $\begin{array}{l}\text { Conservation } \\
\text { Outlook } 2017\end{array}$ & $\begin{array}{l}\text { Conservation } \\
\text { Outlook } 2020\end{array}$ & Values & Threats & $\begin{array}{l}\text { Protection and } \\
\text { management }\end{array}$ \\
\hline Wadi Al-Hitan (Whale Valley) & Egypt & $\begin{array}{l}\text { Good with some } \\
\text { concerns }\end{array}$ & Good & & & \\
\hline
\end{tabular}

* The columns Values, Threats and Protection and Management show the change in these aspects (arrows) and the 2020 rating (colours) 


\section{Cood with some concerns}

If a site's conservation outlook is "good with some concerns", it indicates that its values are currently in good condition and are likely to be maintained in the long term, provided that minor additional conservation measures are put in place to address existing concerns. It is hoped that these sites will address these issues and seek to move to an improved conservation outlook in future assessments. The IUCN World Heritage Outlook 3 assesses the following 112 sites to have a conservation outlook that is good with some concerns:

Country

Seychelles

Cuba

Mexico

South Africa

Jamaica

Uganda

Canada

South Africa

USA

Brazil

Russian Federation

Suriname

Brazil

France

Colombia

Côte d'Ivoire

Romania

Cuba

Gabon

Mexico

China

Australia

UK

Russian Federation

Turkey

USA

India

USA

Canada

France
Site

Aldabra Atoll

Alejandro de Humboldt National Park

Archipiélago de Revillagigedo

* Barberton Makhonjwa Mountains

Blue and John Crow Mountains

Bwindi Impenetrable National Park

Canadian Rocky Mountain Parks

Cape Floral Region Protected Areas

Carlsbad Caverns National Park

Central Amazon Conservation Complex

Central Sikhote-Alin

Central Suriname Nature Reserve

Cerrado Protected Areas: Chapada dos Veadeiros and Emas National Parks

* Chaîne des Puys - Limagne fault tectonic arena

* Chiribiquete National Park - "The Maloca of the Jaguar"

A Comoé National Park

Danube Delta

Desembarco del Granma National Park

Ecosystem and Relict Cultural Landscape of Lopé-Okanda

El Pinacate and Gran Desierto de Altar Biosphere Reserve

* Fanjingshan

Fraser Island

A Giant's Causeway and Causeway Coast

Golden Mountains of Altai

Göreme National Park and the Rock Sites of Cappadocia

Grand Canyon National Park

Great Himalayan National Park Conservation Area

Great Smoky Mountains National Park

Gros Morne National Park

Gulf of Porto: Calanche of Piana, Gulf of Girolata, Scandola Reserve 
Country

Malaysia

Viet Nam

Turkey

China

China

Denmark

South Africa

Italy

China

India

India

Tanzania

Malaysia

Canada, USA

France

Mongolia, Russian Federation

Portugal

Argentina

Australia

Colombia

USA

Greece

Dominica

Zambia, Zimbabwe

Greece

Kenya

China

China

Canada

India

Tanzania

Australia

Bolivia

Japan

Botswana

USA

USA

Brazil

Argentina

Kiribati

Philippines

France, Spain

China

USA

Peru

Palau

Uganda
Site

v Gunung Mulu National Park

Ha Long Bay

Hierapolis-Pamukkale

Huanglong Scenic and Historic Interest Area

Hubei Shennongjia

Ilulissat Icefjord

iSimangaliso Wetland Park

Isole Eolie (Aeolian Islands)

Jiuzhaigou Valley Scenic and Historic Interest Area

Kaziranga National Park

Keoladeo National Park

Kilimanjaro National Park

Kinabalu Park

Kluane / Wrangell-St Elias / Glacier Bay / Tatshenshini-Alsek

Lagoons of New Caledonia: Reef Diversity and Associated Ecosystems

Landscapes of Dauria

- Laurisilva of Madeira

Los Glaciares National Park

Macquarie Island

Malpelo Fauna and Flora Sanctuary

Mammoth Cave National Park

Meteora

Morne Trois Pitons National Park

Mosi-oa-Tunya / Victoria Falls

Mount Athos

Mount Kenya National Park/Natural Forest

Mount Taishan

Mount Wuyi

Nahanni National Park

Nanda Devi and Valley of Flowers National Parks

Ngorongoro Conservation Area

$\boldsymbol{\nabla}$ Ningaloo Coast

Noel Kempff Mercado National Park

Ogasawara Islands

Okavango Delta

Olympic National Park

V Papahānaumokuākea

* Paraty and Illha Grande - Culture and Biodiversity

A Península Valdés

Phoenix Islands Protected Area

Puerto-Princesa Subterranean River National Park

Pyrénées - Mont Perdu

Qinghai Hoh Xil

Redwood National and State Parks

Rio Abiseo National Park

Rock Islands Southern Lagoon

Rwenzori Mountains National Park 
IUCN WORLD HERITAGE OUTLOOK 3

\begin{tabular}{|c|c|c|}
\hline Country & & Site \\
\hline Sudan & & Sanganeb Marine National Park and Dungonab Bay - Mukkawar Island Marine National Park \\
\hline Ecuador & & Sangay National Park \\
\hline Kazakhstan & & Saryarka - Steppe and Lakes of Northern Kazakhstan \\
\hline Australia & $\boldsymbol{\nabla}$ & Shark Bay, Western Australia \\
\hline Japan & & Shiretoko \\
\hline Mexico & & Sian Ka'an \\
\hline China & & Sichuan Giant Panda Sanctuaries - Wolong, Mount Siguniang \& Jiajin Mountains \\
\hline Slovenia & & Škocjan Caves \\
\hline China & & South China Karst \\
\hline Bulgaria & & Srebarna Nature Reserve \\
\hline India & & Sundarbans National Park \\
\hline Switzerland & & Swiss Alps Jungfrau-Aletsch \\
\hline Côte d'Ivoire & & Taï National Park \\
\hline Tajikistan & & Tajik National Park (Mountains of the Pamirs) \\
\hline Australia & & Tasmanian Wilderness \\
\hline Algeria & & Tassili n’Ajjer \\
\hline New Zealand & & Te Wahipounamu - South West New Zealand \\
\hline Mexico & 丸 & Tehuacán-Cuicatlán Valley: originary habitat of Mesoamerica \\
\hline Italy & & The Dolomites \\
\hline Thailand & & Thungyai-Huai Kha Khaeng Wildlife Sanctuaries \\
\hline Guatemala & & Tikal National Park \\
\hline Viet Nam & $\mathbf{\Delta}$ & Trang An Landscape Complex \\
\hline Madagascar & & Tsingy de Bemaraha Strict Nature Reserve \\
\hline Philippines & & Tubbataha Reefs Natural Park \\
\hline Indonesia & & Ujung Kulon National Park \\
\hline Mongolia, Russian Federation & & Uvs Nuur Basin \\
\hline Seychelles & & Vallée de Mai Nature Reserve \\
\hline Jordan & & Wadi Rum Protected Area \\
\hline Canada, USA & & Waterton-Glacier International Peace Park \\
\hline Mexico & & Whale Sanctuary of El Vizcaíno \\
\hline China & $\Delta$ & Wulingyuan Scenic and Historic Interest Area \\
\hline China & & Xinjiang Tianshan \\
\hline Japan & & Yakushima \\
\hline USA & & Yellowstone National Park \\
\hline USA & & Yosemite National Park \\
\hline
\end{tabular}

A The conservation outlook improved since $2017 \quad \boldsymbol{\nabla}$ The conservation outlook deteriorated since 2017

* New site inscribed on the World Heritage List since 2018 
Sites with an improved conservation outlook since $2017^{*}$

\begin{tabular}{|c|c|c|c|c|c|c|}
\hline Site & Country & $\begin{array}{l}\text { Conservation } \\
\text { Outlook } 2017\end{array}$ & $\begin{array}{l}\text { Conservation } \\
\text { Outlook } 2020\end{array}$ & Values & Threats & $\begin{array}{l}\text { Protection and } \\
\text { management }\end{array}$ \\
\hline Comoé National Park & Côte d'Ivoire & Significant concern & $\begin{array}{l}\text { Good with some } \\
\text { concerns }\end{array}$ & & & \\
\hline $\begin{array}{l}\text { Giant's Causeway and } \\
\text { Causeway Coast }\end{array}$ & UK & Significant concern & $\begin{array}{l}\text { Good with some } \\
\text { concerns }\end{array}$ & & & \\
\hline Laurisilva of Madeira & Portugal & Significant concern & $\begin{array}{l}\text { Good with some } \\
\text { concerns }\end{array}$ & & & \\
\hline Península Valdés & Argentina & Significant concern & $\begin{array}{l}\text { Good with some } \\
\text { concerns }\end{array}$ & & & \\
\hline $\begin{array}{l}\text { Trang An Landscape } \\
\text { Complex }\end{array}$ & Viet Nam & Significant concern & $\begin{array}{l}\text { Good with some } \\
\text { concerns }\end{array}$ & & & \\
\hline $\begin{array}{l}\text { Wulingyuan Scenic and } \\
\text { Historic Interest Area }\end{array}$ & China & Significant concern & $\begin{array}{l}\text { Good with some } \\
\text { concerns }\end{array}$ & & & \\
\hline
\end{tabular}

Sites with a deteriorated conservation outlook since 2017

\begin{tabular}{|c|c|c|c|c|c|c|}
\hline Site & Country & $\begin{array}{l}\text { Conservation } \\
\text { Outlook } 2017\end{array}$ & $\begin{array}{l}\text { Conservation } \\
\text { Outlook } 2020\end{array}$ & Values & Threats & $\begin{array}{l}\text { Protection and } \\
\text { management }\end{array}$ \\
\hline Gunung Mulu National Park & Malaysia & Good & $\begin{array}{l}\text { Good with some } \\
\text { concerns }\end{array}$ & & & \\
\hline Ningaloo Coast & Australia & Good & $\begin{array}{l}\text { Good with some } \\
\text { concerns }\end{array}$ & & & \\
\hline Papahānaumokuākea & USA & Good & $\begin{array}{l}\text { Good with some } \\
\text { concerns }\end{array}$ & & & \\
\hline $\begin{array}{l}\text { Shark Bay, Western } \\
\text { Australia }\end{array}$ & Australia & Good & $\begin{array}{l}\text { Good with some } \\
\text { concerns }\end{array}$ & & & \\
\hline
\end{tabular}

* The columns Values, Threats and Protection and Management show the change in these aspects (arrows) and the 2020 rating (colours) 


\begin{tabular}{|c|c|c|}
\hline Country & & Site \\
\hline Peru & & Huascarán National Park \\
\hline Iran & $\star$ & Hyrcanian Forests \\
\hline Spain & & Ibiza: Biodiversity and Culture \\
\hline Tunisia & $\boldsymbol{\nabla}$ & Ichkeul National Park \\
\hline Brazil & & Iguaçu National Park \\
\hline Argentina & & Iguazú National Park \\
\hline Australia & & Kakadu National Park \\
\hline Kenya & $\nabla$ & Kenya Lake System in the Great Rift Valley \\
\hline Indonesia & & Komodo National Park \\
\hline Russian Federation & & Lake Baikal \\
\hline Malawi & & Lake Malawi National Park \\
\hline Indonesia & & Lorentz National Park \\
\hline Colombia & & Los Katios National Park \\
\hline Lesotho, South Africa & $\nabla$ & Maloti-Drakensberg Park \\
\hline Zimbabwe & & Mana Pools National Park, Sapi and Chewore Safari Areas \\
\hline India & & Manas Wildlife Sanctuary \\
\hline Peru & & Manú National Park \\
\hline China & * & Migratory Bird Sanctuaries along the Coast of Yellow Sea-Bohai Gulf of China (Phase I) \\
\hline Mexico & $\boldsymbol{\Delta}$ & Monarch Butterfly Biosphere Reserve \\
\hline Albania, North Macedonia & & Natural and Cultural Heritage of the Ohrid region \\
\hline Russian Federation & & Natural System of Wrangel Island Reserve \\
\hline Brazil & & Pantanal Conservation Area \\
\hline Viet Nam & $\nabla$ & Phong Nha-Ke Bang National Park \\
\hline Bulgaria & & Pirin National Park \\
\hline Saint Lucia & & Pitons Management Area \\
\hline France & & Pitons, cirques and remparts of Reunion Island \\
\hline Croatia & & Plitvice Lakes National Park \\
\hline Madagascar & & Rainforests of the Atsinanana \\
\hline Nepal & & Sagarmatha National Park \\
\hline Cameroon, Central African & & Sangha Trinational \\
\hline Republic, Congo & & \\
\hline Tanzania & $\nabla$ & Serengeti National Park \\
\hline Ethiopia & & Simien National Park \\
\hline Sri Lanka & & Sinharaja Forest Reserve \\
\hline Yemen & & Socotra Archipelago \\
\hline Costa Rica, Panama & & Talamanca Range-La Amistad Reserves / La Amistad National Park \\
\hline Iraq & & The Ahwar of Southern Iraq: Refuge of Biodiversity and the Relict Landscape of the Mesopotamian Cities \\
\hline Bangladesh & & The Sundarbans \\
\hline China & & Three Parallel Rivers of Yunnan Protected Areas \\
\hline Russian Federation & & Virgin Komi Forests \\
\hline Russian Federation & & Volcanoes of Kamchatka \\
\hline South Africa & & Vredefort Dome \\
\hline Benin, Burkina Faso, Niger & $\nabla$ & W-Arly-Pendjari Complex \\
\hline Russian Federation & & Western Caucasus \\
\hline India & & Western Ghats \\
\hline Kazakhstan, Kyrgyzstan, Uzbekistan & & Western Tien-Shan \\
\hline Australia & & Wet Tropics of Queensland \\
\hline Canada & & Wood Buffalo National Park \\
\hline
\end{tabular}

A The conservation outlook improved since 2017

The conservation outlook deteriorated since 2017

* New site inscribed on the World Heritage List since 2018 
IUCN WORLD HERITAGE OUTLOOK 3

Sites with an improved conservation outlook since $2017^{\star}$

\begin{tabular}{|c|c|c|c|c|c|c|}
\hline Site & Country & $\begin{array}{l}\text { Conservation } \\
\text { Outlook } 2017\end{array}$ & $\begin{array}{l}\text { Conservation } \\
\text { Outlook } 2020\end{array}$ & Values & Threats & $\begin{array}{l}\text { Protection and } \\
\text { management }\end{array}$ \\
\hline $\begin{array}{l}\text { Monarch Butterfly Biosphere } \\
\text { Reserve }\end{array}$ & Mexico & Critical & $\begin{array}{l}\text { Significant } \\
\text { concern }\end{array}$ & & & \\
\hline
\end{tabular}

Sites with a deteriorated conservation outlook since 2017

\begin{tabular}{|c|c|c|c|c|c|c|}
\hline Site & Country & $\begin{array}{l}\text { Conservation } \\
\text { Outlook } 2017\end{array}$ & $\begin{array}{l}\text { Conservation } \\
\text { Outlook } 2020\end{array}$ & Values & Threats & $\begin{array}{l}\text { Protection and } \\
\text { management }\end{array}$ \\
\hline $\begin{array}{l}\text { Brazilian Atlantic Islands: } \\
\text { Fernando de Noronha and } \\
\text { Atol das Rocas Reserves }\end{array}$ & Brazil & $\begin{array}{l}\text { Good with some } \\
\text { concerns }\end{array}$ & $\begin{array}{l}\text { Significant } \\
\text { concern }\end{array}$ & & & \\
\hline $\begin{array}{l}\text { Central Highlands of Sri } \\
\text { Lanka }\end{array}$ & Sri Lanka & $\begin{array}{l}\text { Good with some } \\
\text { concerns }\end{array}$ & $\begin{array}{l}\text { Significant } \\
\text { concern }\end{array}$ & & & \\
\hline $\begin{array}{l}\text { Gondwana Rainforests of } \\
\text { Australia }\end{array}$ & Australia & $\begin{array}{l}\text { Good with some } \\
\text { concerns }\end{array}$ & $\begin{array}{l}\text { Significant } \\
\text { concern }\end{array}$ & & & \\
\hline $\begin{array}{l}\text { Greater Blue Mountains } \\
\text { Area }\end{array}$ & Australia & $\begin{array}{l}\text { Good with some } \\
\text { concerns }\end{array}$ & $\begin{array}{l}\text { Significant } \\
\text { concern }\end{array}$ & & & \\
\hline Ichkeul National Park & Tunisia & $\begin{array}{l}\text { Good with some } \\
\text { concerns }\end{array}$ & $\begin{array}{l}\text { Significant } \\
\text { concern }\end{array}$ & & & \\
\hline $\begin{array}{l}\text { Kenya Lake System in the } \\
\text { Great Rift Valley }\end{array}$ & Kenya & $\begin{array}{l}\text { Good with some } \\
\text { concerns }\end{array}$ & $\begin{array}{l}\text { Significant } \\
\text { concern }\end{array}$ & & & \\
\hline Maloti-Drakensberg Park & $\begin{array}{l}\text { Lesotho, } \\
\text { South } \\
\text { Africa }\end{array}$ & $\begin{array}{l}\text { Good with some } \\
\text { concerns }\end{array}$ & $\begin{array}{l}\text { Significant } \\
\text { concern }\end{array}$ & & & \\
\hline $\begin{array}{l}\text { Phong Nha-Ke Bang } \\
\text { National Park }\end{array}$ & Viet Nam & $\begin{array}{l}\text { Good with some } \\
\text { concerns }\end{array}$ & $\begin{array}{l}\text { Significant } \\
\text { concern }\end{array}$ & & & \\
\hline Serengeti National Park & Tanzania & $\begin{array}{l}\text { Good with some } \\
\text { concerns }\end{array}$ & $\begin{array}{l}\text { Significant } \\
\text { concern }\end{array}$ & & & \\
\hline W-Arly-Pendjari Complex & $\begin{array}{l}\text { Benin, } \\
\text { Burkina } \\
\text { Faso, Niger }\end{array}$ & $\begin{array}{l}\text { Good with some } \\
\text { concerns }\end{array}$ & $\begin{array}{l}\text { Significant } \\
\text { concern }\end{array}$ & & & \\
\hline
\end{tabular}

* The columns Values, Threats and Protection and Management show the change in these aspects (arrows) and the 2020 rating (colours) 


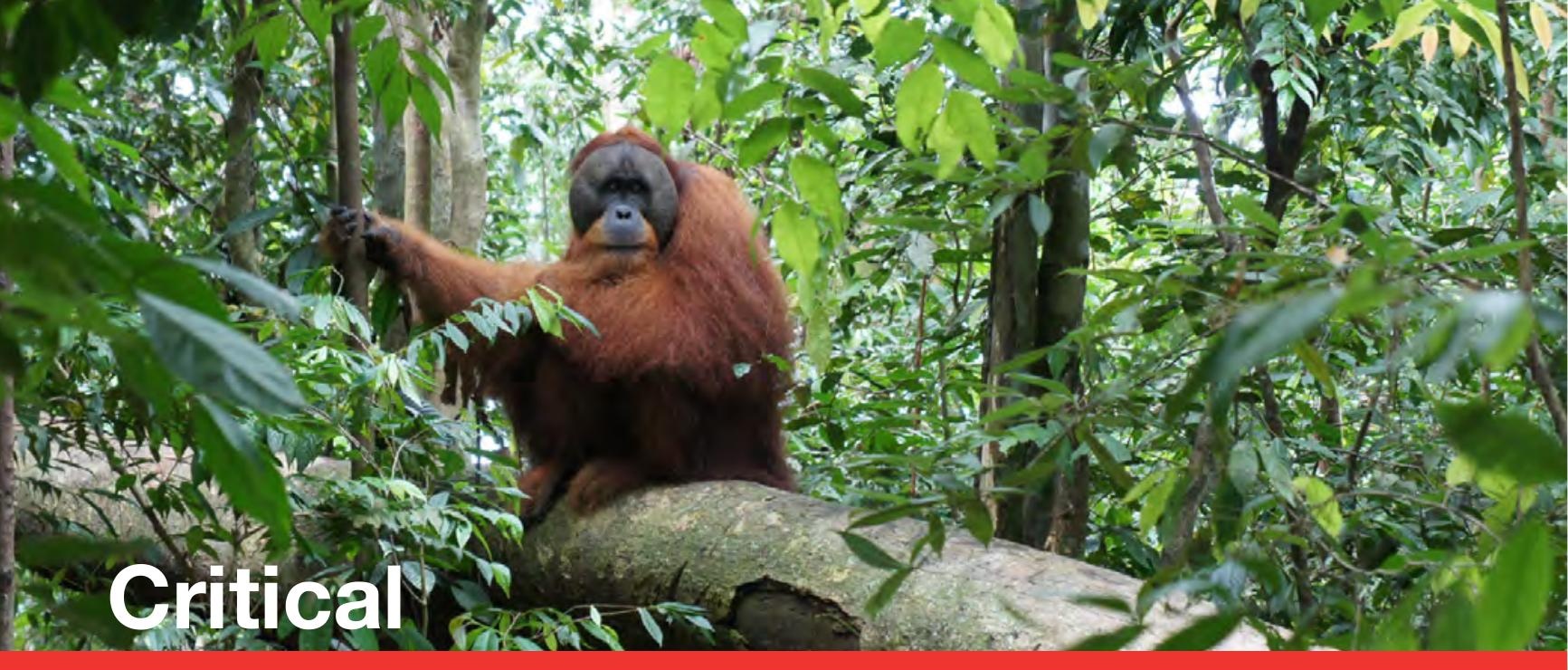

Sites with a "critical" conservation outlook are severely threatened and require urgent, additional and large-scale conservation measures, or their values may be lost. These sites face a range of threats and in many cases have low capacity to address them. Often, however, the issues span national borders and international attention is urgently needed to help mitigate those threats and prevent these sites from irreversibly losing their values. Many of these sites are included on the List of World Heritage in Danger. They should be the highest priority for conservation action within the World Heritage Convention. While one site has moved out of a critical outlook since 2017, two new entries are now on the list below. The IUCN World Heritage Outlook 3 assesses the following 18 sites to have a critical conservation outlook.

\begin{tabular}{ll} 
Country & Site \\
\hline Niger & Aïr and Ténéré Natural Reserves \\
\hline Cameroon & Dja Faunal Reserve \\
\hline Solomon Islands & East Rennell \\
\hline USA & Everglades National Park \\
\hline Democratic Republic of the Congo & Garamba National Park \\
\hline Australia & $\boldsymbol{\nabla}$ \\
\hline Mexico & Great Barrier Reef \\
\hline Democratic Republic of the Congo & Islands and Protected Areas of the Gulf of California \\
\hline Kenya & Kahuzi-Biéga National Park \\
\hline Central African Republic & Lake Turkana National Parks \\
\hline Côte d'Ivoire, Guinea & Manovo-Gounda St Floris National Park \\
\hline Senegal & Mount Nimba Strict Nature Reserve \\
\hline Democratic Republic of the Congo & Niokolo-Koba National Park \\
\hline Honduras & Okapi Wildlife Reserve \\
\hline Democratic Republic of the Congo & Río Plátano Biosphere Reserve \\
\hline Tanzania & Salonga National Park \\
\hline Indonesia & Selous Game Reserve \\
\hline Democratic Republic of the Congo & Tropical Rainforest Heritage of Sumatra \\
\hline
\end{tabular}

$\Delta$ The conservation outlook improved since $2017 \quad \boldsymbol{\nabla}$ The conservation outlook deteriorated since 2017

Sites with a deteriorated conservation outlook since $2017^{\star}$

\begin{tabular}{|c|c|c|c|c|c|c|}
\hline Site & Country & $\begin{array}{l}\text { Conservation } \\
\text { Outlook } 2017\end{array}$ & $\begin{array}{l}\text { Conservation } \\
\text { Outlook } 2020\end{array}$ & Values & Threats & $\begin{array}{l}\text { Protection and } \\
\text { management }\end{array}$ \\
\hline Great Barrier Reef & Australia & Significant concern & Critical & & & \\
\hline $\begin{array}{l}\text { Islands and Protected Areas } \\
\text { of the Gulf of California }\end{array}$ & Mexico & Significant concern & Critical & & & \\
\hline
\end{tabular}

* The columns Values, Threats and Protection and Management show the change in these aspects (arrows) and the 2020 rating (colours) 


\section{Values}

The concept of Outstanding Universal Value (OUV) is central to the World Heritage Convention. OUV is defined as "cultural and/or natural significance which is so exceptional as to transcend national boundaries and to be of common importance for present and future generations of all humanity" (UNESCO, 2019).

Four criteria of Outstanding Universal Value, out of a total of 10, refer to natural values. Criterion (vii) recognises outstanding natural beauty and exceptional phenomena; criterion (viii) geoheritage; while criteria (ix) and (x) are linked to biodiversity, i.e. ecosystems and species. A site can be inscribed under one or several criteria, including cultural criteria, in which case it is defined as a "mixed" site. The IUCN World Heritage Outlook only considers natural values.

The IUCN World Heritage Outlook identifies and describes one or several values under each criterion for which a site is inscribed (e.g. "endemic mammal species", "the most dramatic known manifestation of the phenomenon of insect migration"). The current state of these values is then assessed against four possible categories: good, low concem, high concern or critical.

Overall, the state of World Heritage values in $68 \%$ of sites is considered to be good or of low concern, while in $28 \%$ the state of values is of high concern and in $4 \%$ critical.

Figure 4. Overall state of values of all natural World Heritage sites in $2020(n=252)$.

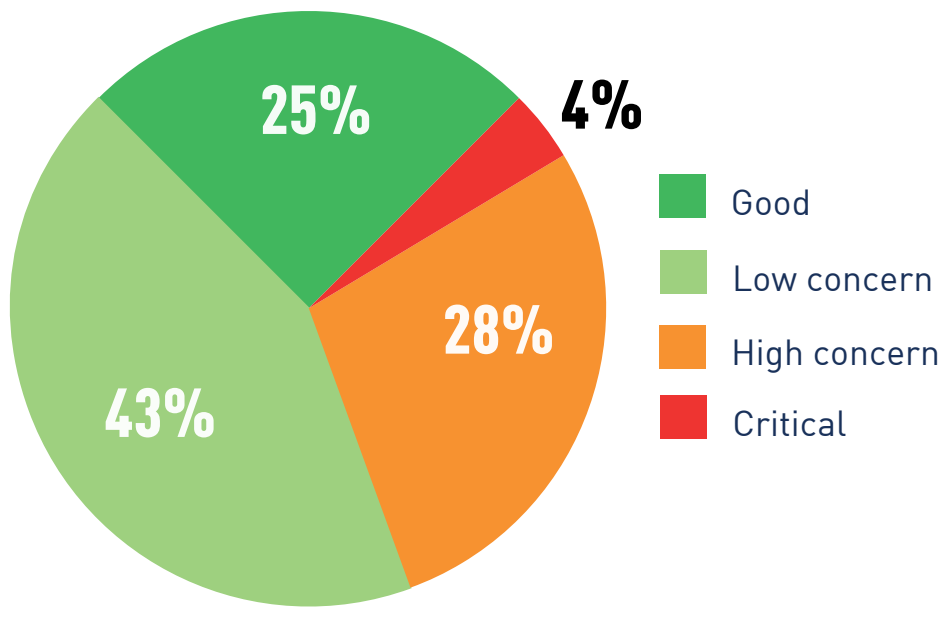

Compared with overall ratings presented in Conservation Outlook Assessments, the assessment of World Heritage "values" specifically shows better results. In 60 sites, values were rated differently than their overall conservation outlook, and in the majority of them (50), the values' assessment showed lower concern.

The reasons for this are likely to differ between sites and there are a number of hypotheses. In some cases, this could be due to values staying resilient despite the pressures they are under. In other cases, values may benefit from effective protection and management strategies to mitigate high threats, but those same threats impact the overall conservation outlook rating. Conversely, concerns over insufficient protection and management, which are reflected in the Conservation Outlook Assessment, may not yet have had significant impacts on the values, but could in the future if not addressed. Finally the growing and emerging new threats identified in this report, do not yet impact on the values, so there are both opportunities and risks for the future.

It is important to recall that Conservation Outlook Assessments offer a forward-looking analysis, projecting into the future the likelihood that sites will retain their OUV. In several cases there will be a lag time between the current situation and a future state. 


\section{The four natural criteria for World Heritage status}

To be deemed of Outstanding Universal Value a site needs to meet one or more of the World Heritage criteria. Criteria (vii)-(x) are applied to natural sites:

(vii) contain superlative natural phenomena or areas of exceptional natural beauty and aesthetic importance;

(viii) be outstanding examples representing major stages of Earth's history, including the record of life, significant ongoing geological processes in the development of landforms, or significant geomorphic or physiographic features;

(ix) be outstanding examples representing significant on-going ecological and biological processes in the evolution and development of terrestrial, fresh water, coastal and marine ecosystems and communities of plants and animals;

(x) contain the most important and significant natural habitats for in-situ conservation of biological diversity, including those containing threatened species of Outstanding Universal Value from the point of view of science or conservation (UNESCO, 2019).

A comparison between 2014, 2017 and 2020 for the 228 sites, for which three data sets are now available, shows a continued decrease in the number of sites whose values were assessed as being in a good state overall. This trend is consistent with the comparison of overall conservation outlook over time, discussed above and shown in Figure 2. It is cause for concern should this declining trend continue, as it signals that even the most intact and well-managed sites are not immune to pressures. We need more, not fewer, sites demonstrating the benefits of good practice to achieve improved conservation outcomes.

Figure 5. Overall state of values of all natural World Heritage sites in 2014, 2017 and 2020

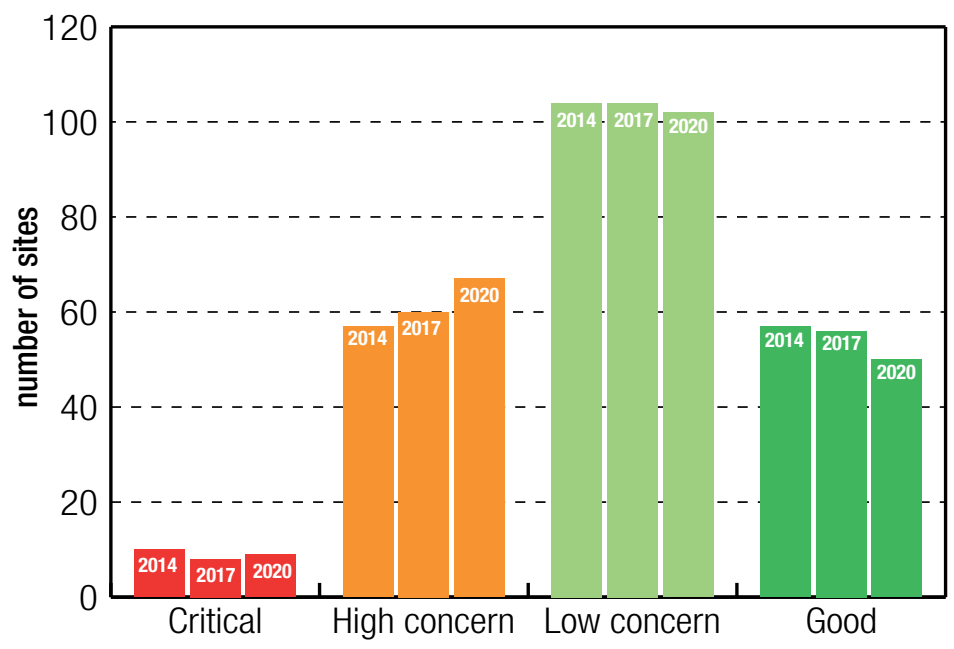

When considering values associated with different criteria, the results are similar to previous assessment cycles: the biodiversity values - criteria (ix) referring to ecological processes, and $(x)$ to species and habitats - continue to be more often assessed as of high concern or critical than values related to exceptional natural beauty (criterion vii) and geology (criterion viii).

While overall the picture is very similar to that in 2017, the situation has slightly worsened for values recognised for their importance for species under criterion (x). Only 58\% of values related to species and habitats are assessed to be in a good state or of low concern in 2020, compared to 62\% in 2017. 


\section{Vallée de Mai Nature Reserve (Seychelles) - effective action for the endemic coco-de-mer}

Vallée de Mai Nature Reserve was inscribed on the World Heritage List in 1983 under all four natural criteria. Criterion $(x)$ recognises the site as the world's stronghold for several endemic palm trees - species found nowhere else on Earth, including the Endangered coco-de-mer (Lodoicea maldivica). The palm forest provides refuge for a number of endemic animals, including the Seychelles black parrot (Coracopsis barklyi), assessed as Vulnerable by the IUCN Red List of Threatened Species.

Thanks to effective action to protect its unique biodiversity, the site has succeeded in maintaining a conservation outlook assessed as "good with some concerns". Measures targeting illegal collection of palm nuts, and renewed efforts invested in monitoring and research to support science-based decision-making, have all contributed to improve the site's protection and management in recent years.

Figure 6. State of World Heritage values associated with different criteria of all 252 natural World Heritage sites in 2020.

(vii) - Exceptional beauty and phenomena

(viii) - Geology

(ix) - Ecological processes

$(\mathrm{x})$ - Species and habitats

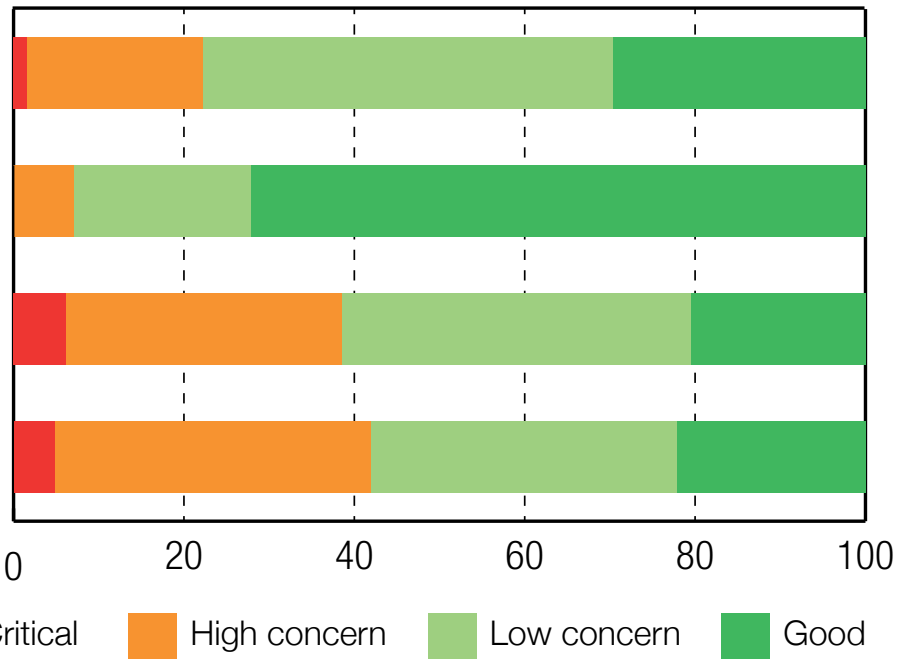

\section{Biodiversity values}

Natural World Heritage sites, particularly those inscribed under criteria (ix) and (x) are highly important for the protection of globally endangered and endemic species. Many of these sites represent the last hope for the preservation of some iconic species of flora and fauna. Biodiversity and ecosystem integrity are also fundamental as they underpin important ecosystem services, which are now more important than ever as the world is facing an unprecedented global environmental crisis.

While the data above (Figure 6) shows that these values are the most affected ones, many natural sites offer examples of effective management for species conservation and offer solutions that can be replicated elsewhere.

\section{Different threats for different values}

This report presents the first analysis of how the different criteria of World Heritage values face a particular set of threats. The following chapter describes in greater detail results on the threats identified in the Conservation Outlook Assessments.

Climate change emerges as the most common threat for all types of natural World Heritage values. It is followed by invasive alien species in the case of biodiversity-related values (criteria ix and $x$ ). In the case of species and habitats (criterion $\mathrm{x}$ ), this is followed by dams and in the case of ecological processes (criterion ix), by impacts of visitation. 
Impacts of visitation is also the second most common current threat affecting values under criteria (viii) (exceptional beauty and phenomena) and (viiii) (geology). While geological values are generally more robust and have fewer cases of high or very high threat (the figure below represents a percentage of the total number of values affected by threats under each criterion, noting that each criterion has a different number of sites and values associated with it), it is notable that climate change represents such a prominent threat even for these values.

Figure 7. Top five most common threats assessed as high or very high for values under different criteria

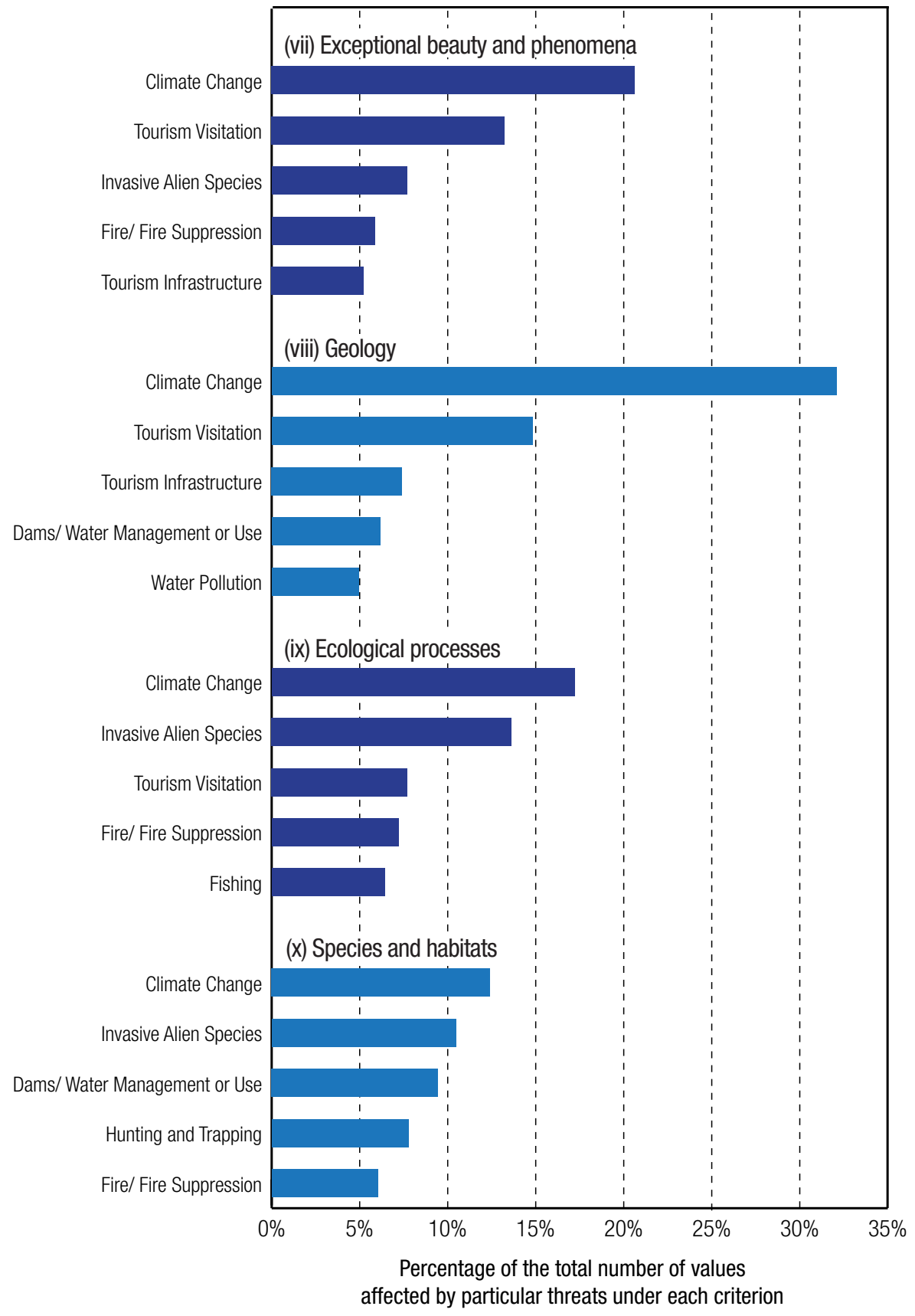




\section{Threats}

The IUCN World Heritage Outlook identifies and evaluates current and potential threats affecting natural World Heritage sites. Current threats refer to activities or factors that have an immediately apparent impact affecting a site's values, such as built infrastructure, invasive alien species, tourism or natural disasters, while potential threats refer to planned activities or evolving trends that could have a future impact if they materialise, such as infrastructure projects or rising global temperatures. For each identified threat, its level is assessed against four possible categories: very low, low, high or very high.

The threats classification used for the IUCN World Heritage Outlook is adapted from the Open Standards for the Practice of Conservation threats classification² (version 1), a classification widely used in the field of nature conservation, including by the IUCN Red List of Threatened Species. The Open Standards' classification features broad categories of threats (e.g. geological events), which are then divided into further sub-categories (e.g. volcanoes, earthquakes/tsunamis, avalanches/landslides).

The IUCN World Heritage Outlook 3 shows that natural World Heritage sites are increasingly facing a wide range of threats and pressures. The two sub-sections below provide a comparison between 2014, 2017 and 2020 assessments of current and potential threats affecting the 228 sites inscribed on the World Heritage List up to 2014. The figures reflect the number of sites where threats were assessed as high or very high.

\section{Current threats}

Climate change continues to affect more and more natural World Heritage sites. In 2017, the IUCN World Heritage Outlook showed it was the fastest growing threat; now climate change has effectively become the most prevalent current threat. Overall, it is assessed as a high or a very high threat in 83 out of 252 sites. The graph below presents comparative results for the 228 sites, for which three data sets are available, and therefore only shows 76 sites affected by climate change.

The impacts of climate change are manifold. They include increasing frequency and severity of fires, coral bleaching, damage from severe weather events, droughts, and facilitated spread of invasive alien species, to name a few. In some sites, increasing impacts associated with climate change (sometimes accompanied by other threats and issues) have resulted in a deteriorated conservation outlook overall, as is the case with the Great Barrier Reef (Australia) which is now assessed as having a "critical" outlook.

Invasive alien species, which was assessed as the top threat both in 2014 and 2017, follows closely behind as now the second most prevalent current threat. Given the evidence that links the spread of invasive alien species with climate change impacts on ecological parameters, a strong link between these two prominent threats is highly likely. Examples where climate change has facilitated the spread of invasive alien species include Cape Floral Region Protected Areas (South Africa) and Garajonay National Park (Spain).

Climate change is also associated with increasing frequency and severity of fires, as was exemplified by some sites which have faced unprecedented fires in 2019-2020, such as Gondwana Rainforests of Australia (Australia) and Pantanal Conservation Area (Brazil). In some cases the combination of climate change, increasing fires and the associated spread of invasive alien species is already changing the sites' ecosystems.

The threat of invasive alien species is followed by impacts from tourism visitation, hunting and trapping, fishing, fires and livestock grazing.

It should be noted that for the 2017 assessment cycle, the sub-categories for hunting were changed in order to distinguish between hunting (commercial or subsistence) and poaching. In 2020, these sub-categories have been merged into one "hunting and trapping" sub-category, with a possibility to indicate whether the activities are legal and/or illegal. Therefore, comparison with 2017 and 2014 for this threat sub-category is not presented in the graph. 
Figure 8. Current threats assessed as high or very high in 2020, 2017 and 2014. Numbers are based on the number of sites where these threats have been registered.

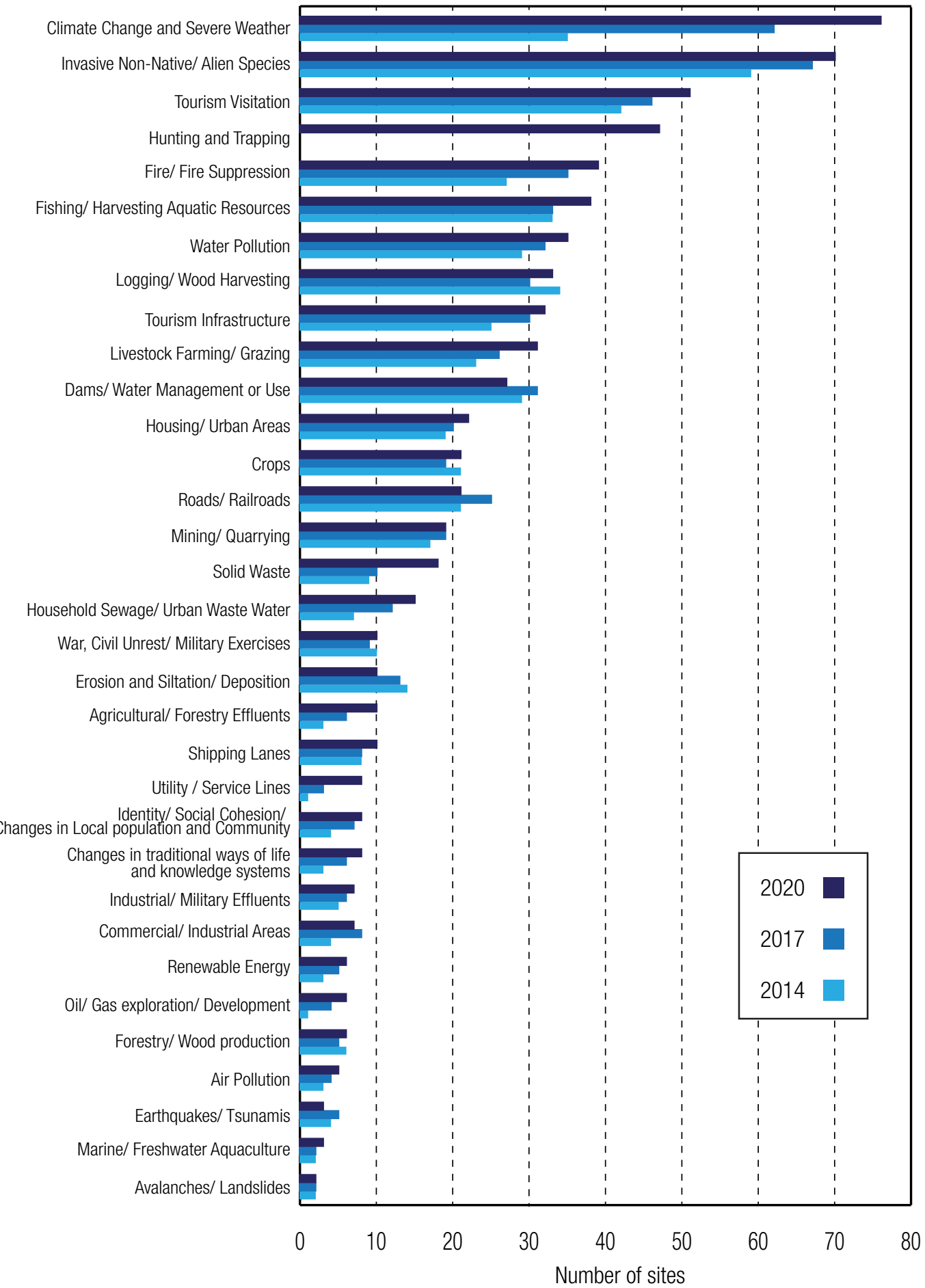


However, distinguishing between legal and/or illegal activities, as assessed in 2020, has allowed for an analysis across all categories of biological resource use.

Resource extraction, such as hunting, fishing and logging, is in the majority of cases associated with illegal activities. However, these activities can also be both legal and illegal, particularly when it comes to fishing; indeed, in many marine sites some form of fishing is permitted (e.g. artisanal fishing). However, levels of legal fishing are often poorly regulated or unsustainable, and illegal fishing can also occur alongside this. For example, in Banc d'Arguin National Park (Mauritania), concerns exist over the levels of legally permitted artisanal fishing, which is becoming increasingly commercial and is adding to pressures from illegal fishing within the site and commercial fishing outside its boundaries, including by international fleets.

\section{World Heritage - a laboratory for addressing climate change By Jon Day and Scott Heron}

Concerns about the impacts of climate change on natural, as well as cultural, World Heritage sites have grown in recent years. The 2020 update of the IUCN World Heritage Outlook confirms that climate change is now the most common current and potential threat to the future conservation of the Outstanding Universal Value (OUV) of natural World Heritage sites. In most affected World Heritage sites, climate change (through direct impacts and exacerbating other compounding threats) is causing a decline in values. The severity of impacts, however, varies in each site, as does the range of climate change stressors - such as sea level rise, floods and droughts and the rates at which these stressors occur. Different ecosystems, habitats and species also display different responses to climate impacts.

As each case is different, there is no one-size-fits-all solution to understand vulnerability at the site level and to address the impacts of climate change. In an attempt to better understand the issues at stake and help identify effective measures, a new tool has been developed: the Climate Vulnerability Index (CVI). The CVI provides a rapid, systematic approach to assess vulnerability in all types of World Heritage sites.

Building on a framework by the Intergovernmental Panel on Climate Change (IPCC), the CVI comprises two distinct stages: OUV Vulnerability and Community Vulnerability. The first stage focuses on assessing potential impacts to the key values and attributes for which a site is inscribed on the World Heritage List. The second stage looks at communities associated with a site through economic, social and cultural connections; their dependency on that site; and on their capacity to adapt to climate change.

To date, the CVI has been applied in two natural World Heritage sites: Shark Bay, Western Australia (2018, 2019), and the Wadden Sea, Denmark, Germany and the Netherlands (2020); and in one cultural site: the Heart of Neolithic Orkney, Scotland (2019). CVI applications are underway in several other World Heritage sites. Outcomes from the CVI process helped inform the development adaptation strategies for these sites and how they could be integrated into their respective Management Plan. The systematic nature of the CVI means it can help to prioritise actions, strengthen community and institutional capacity, and improve governance.

While the top three current threats (climate change, invasive alien species and impacts of tourism) have remained the same as in 2017, significant regional differences were observed in 2020, which are discussed below in the chapters presenting regional results. 


\section{Potential threats}

Climate change again tops the list of potential threats in 2020, as it did in 2017. It is now also the fastest growing potential threat to natural World Heritage sites. This indicates the all-pervasive threat of climate change will likely continue to affect more and more sites in the foreseeable future.

Of concern is that potential mining, oil and gas development, and hydropower projects continue to be among the most prominent potential threats assessed as high or very high. There has been a slight increase in the number of sites potentially affected by such developments since 2017. While developments lie mostly outside the boundaries of the sites, these projects can nonetheless pose significant threats to the values within the sites.

Figure 9. Potential threats assessed as high or very high in 2020, 2017 and 2014. Numbers are based on the number of sites where these threats have been registered.

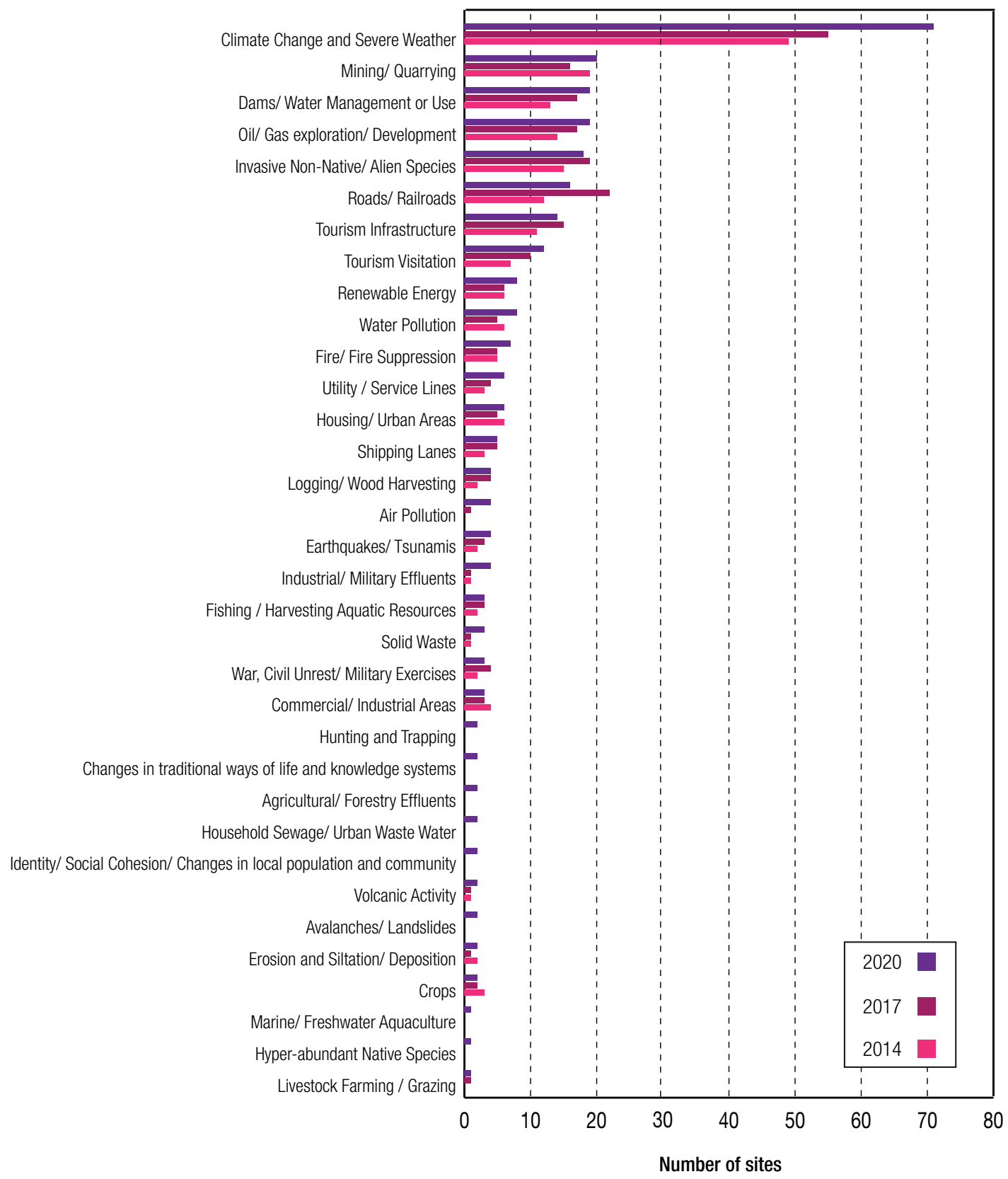




\section{Protection and management}

The IUCN World Heritage Outlook evaluates 15 different aspects of protection and management for sites, including management systems, legislative frameworks, site boundaries, relationships with local people, tourism and visitation management and monitoring ${ }^{3}$. The assessments for each of these categories are used to determine the overall assessment of the protection and management effectiveness of each site.

The 2020 results for all 252 natural World Heritage sites show that 50\% of sites have overall effective or highly effective protection and management and that in 9\% protection and management were assessed as of serious concern.

Figure 10. 2020 results for protection and management, \% of all sites

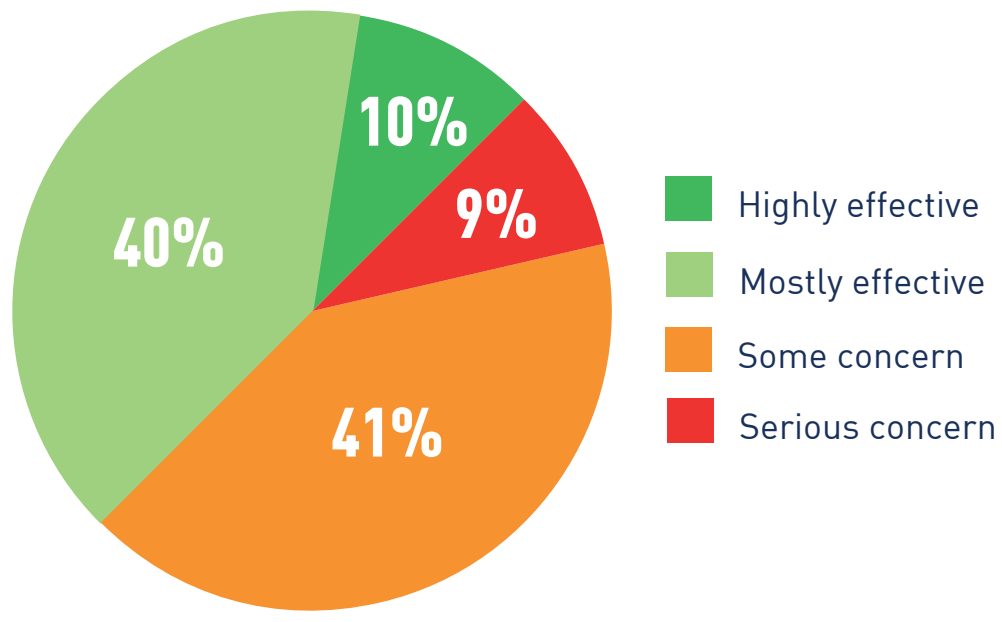

Figure 11. Comparison between 2014, 2017 and 2020 of overall protection and management in 228 sites inscribed up to 2014

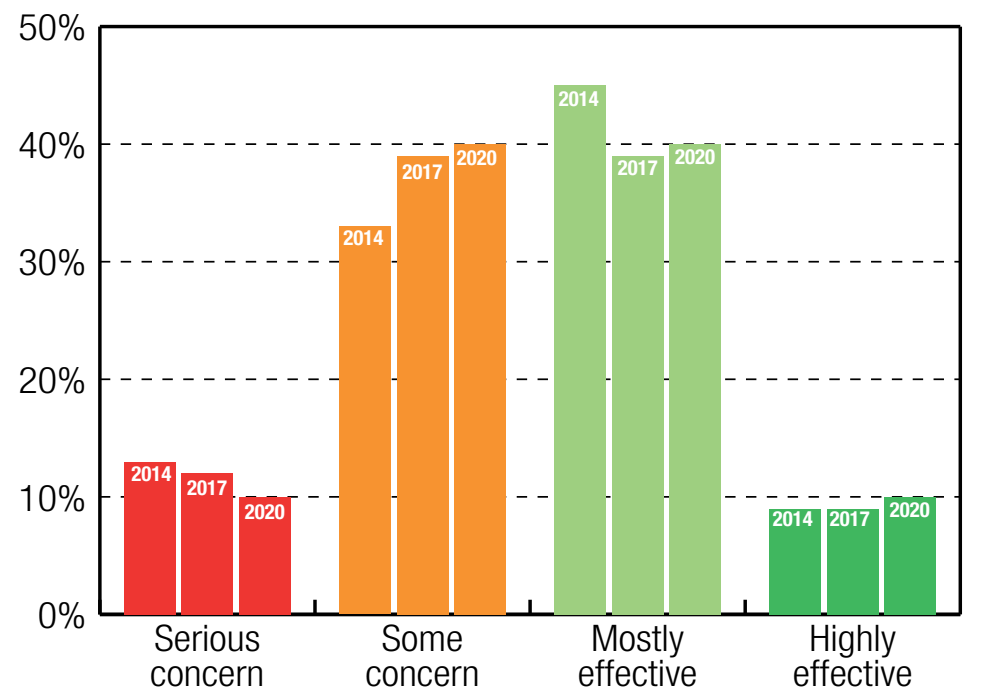

3. The full list of protection and management categories are: management system; effectiveness of management system; boundaries; integration into regional and national planning systems; relationships with local people; legal framework; law enforcement; implementation of Committee decisions and recommendations; sustainable use; sustainable finance; staff capacity, training, and development; education and interpretation programs; tourism and visitation management; monitoring; and research. 
When comparing the results for the 228 sites, for which three data points are now available (Figure 11), it can be noted that overall the results remain similar. Following some reduction between 2014 and 2017, a slight increase has been observed in 2020, compared to 2017, in the percentage of sites with highly or mostly effective protection and management overall (50\% compared to 48\%).

Conservation Outlook Assessments provide data on specific aspects of protection and management. The results presented below show the aspects most frequently assessed as either highly effective (Figure 12) or of serious concern (Figure 13).

Figure 12. Number of sites where specific protection and management aspects were assessed as highly effective in 2020 (top six categories)

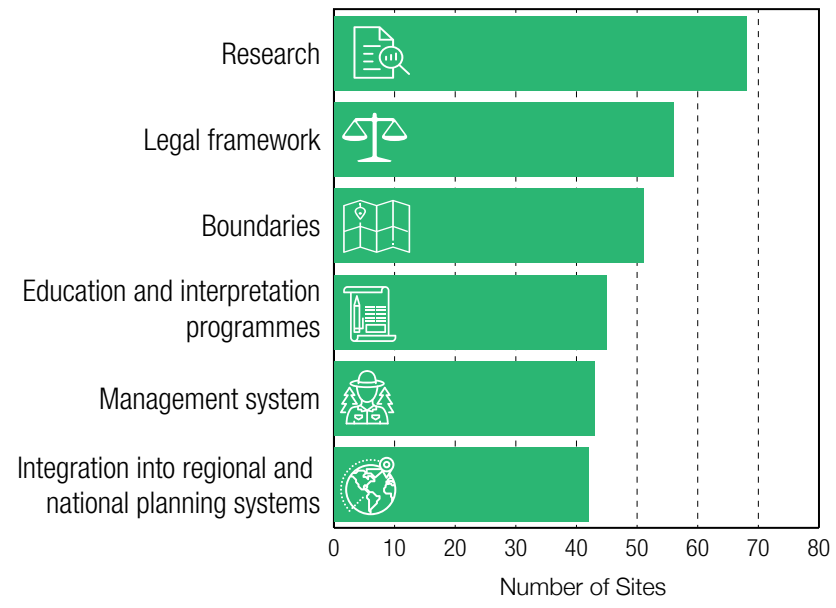

Figure 13. Number of sites where specific protection and management aspects were assessed as being of serious concern in 2020 (top six categories)

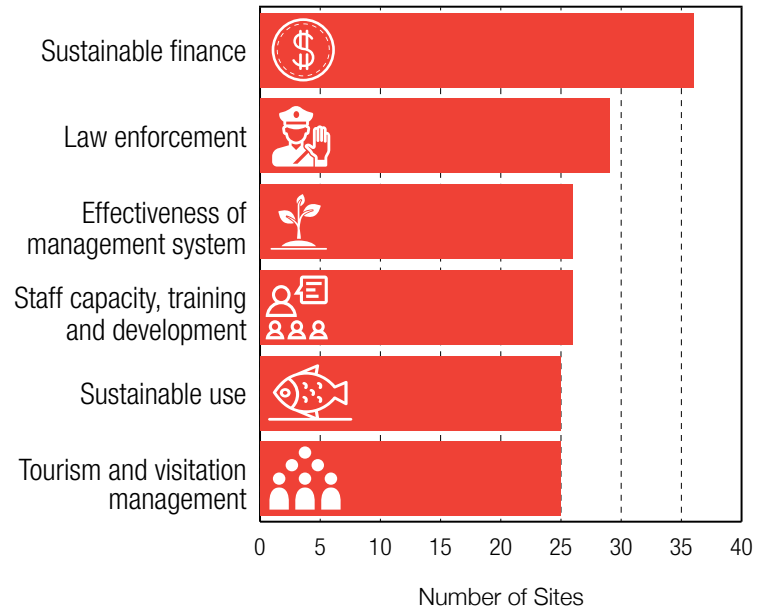

It is alarming that absolutely critical aspects of protection and management, such as sustainable financing, law enforcement, staffing and general management effectiveness remain of serious concern across many natural sites. Sustainable finance was the aspect assessed most frequently as of serious concern in 2017 and it remains the biggest issue in 2020. This signals that much more commitment is needed to adequately resource the protection and management of the world's most precious and irreplaceable places - never more important than in a climate of increasing threats. 


\section{Impacts from COVID-19 on protection and management}

The onset of the Coronavirus disease (COVID-19) and pandemic in 2020 is already having an impact on natural World Heritage sites across all regions of the world, according to the IUCN World Heritage Outlook 3. This unforeseen issue could not be recorded systematically for all sites, since the 2020 update began before COVID-19 became globally widespread. Nevertheless, a picture is emerging of initial impacts in some sites.

Conservation Outlook Assessments from over 50 sites mention actual or potential impacts from COVID-19 in relation to threats or protection and management. Some further assessments note that the consequences of the pandemic remain to be seen.

A few assessments suggest that reduced human activity during the pandemic has had a positive impact on World Heritage values. Most notably, a short-term decrease in tourism visitation has eased pressure on natural ecosystems. However, negative COVID-19 impacts recorded in the assessments are numerous and can be broadly categorised into three areas. Firstly, disruptions in work activities, such as project implementation, site planning and management, and law enforcement and patrolling. Secondly, disruptions caused by a drop in revenue - actual and anticipated - due to a decrease in tourism activities and/or funding and budget.

This sometimes also causes a loss of income and livelihoods for local people. Thirdly, disruptions to wildlife, notably through increases in illegal hunting, fishing and gathering of natural products, but also due to potential transmission of the virus to wild animal populations.

One stark example of the negative effects of the pandemic on World Heritage conservation comes from Bwindi Impenetrable National Park in Uganda. In June 2020, a poacher who entered the park illegally during its closure killed Rafiki, a silverback mountain gorilla known to many of the park's visitors. The Conservation Outlook Assessment indicates that, due to loss of livelihoods associated with the park closing to tourism, poaching has increased since the pandemic. Tourism also funds management activities in the park, such as patrolling, so essential conservation work could cease without alternative funding. The Critically Endangered mountain gorilla, as well as other primates dwelling in Bwindi, are also believed to be vulnerable to transmission of the coronavirus from humans.

While the full extent of short- and long-term impacts of the COVID-19 pandemic are yet to play out for many natural World Heritage sites, it is clear that the issue is multifaceted and complex, and is likely to present management challenges for sites in the near future. 
Results of the IUCN World Heritage Outlook 3 show that, of all natural and mixed World Heritage sites in Africa (total of 43 sites), for $42 \%$ the conservation outlook is assessed as either "good" or "good with some concerns", for 30\% it is "significant concern" and for $28 \%$ the conservation outlook is "critical".

Conservation Outlook 2020 for natural World Heritage sites in Africa

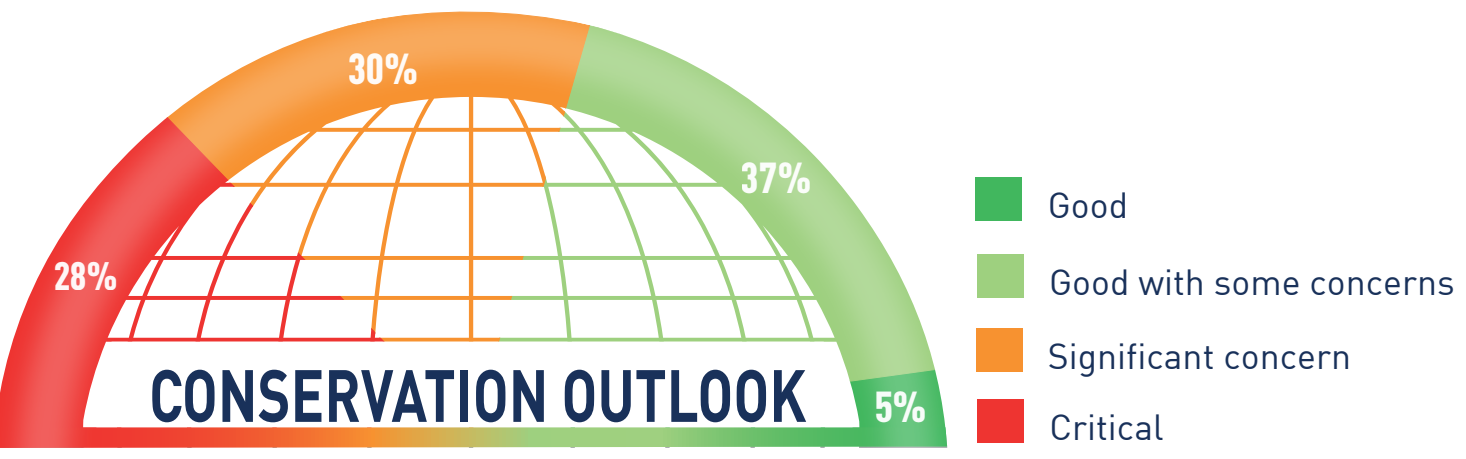

One new site was inscribed in Africa since 2018:

\begin{tabular}{llll} 
Site & Country & Conservation Outlook 2020 & Inscription year \\
\hline Barberton Makhonjwa Mountains & South Africa & Good with some concerns & 2018 \\
\hline
\end{tabular}

Of the sites that were inscribed in 2017 or earlier, and therefore already assessed in the IUCN World Heritage

Outlook 2017, Comoé National Park showed a continued improvement, from "significant concern" in 2017 to "good with some concerns" in 2020, having previously improved from "critical" in 2014 (see text box on page 11 for more details). Four sites deteriorated from "good with some concerns" to "significant concern".

\begin{tabular}{llll} 
Site & Country & Conservation Outlook 2017 & Conservation Outlook 2020 \\
\hline Comoé National Park & Côte d'Ivoire & Significant concern & Good with some concerns \\
\hline $\begin{array}{l}\text { Kenya Lake System in the Great Rift } \\
\text { Valley }\end{array}$ & Kenya & Good with some concerns & Significant concern \\
\hline $\begin{array}{l}\text { Maloti-Drakensberg Park } \\
\text { Serengeti National Park }\end{array}$ & $\begin{array}{l}\text { Lesotho, South } \\
\text { Africa }\end{array}$ & Good with some concerns & Significant concern \\
\hline W-Arly-Pendjari Complex & Tanzania & Good with some concerns & Significant concern \\
\hline & $\begin{array}{l}\text { Benin, Burkina Faso, } \\
\text { Niger }\end{array}$ & Good with some concerns & Significant concern \\
\hline
\end{tabular}

\section{Threats}

The most prevalent current threats to natural sites in Africa are hunting, fires, invasive alien species and logging. This picture is similar to the 2017 findings and the top three threats remained the same. 
Current threats assessed as high or very high in 2020. Figures are based on the number of sites where these threats occur

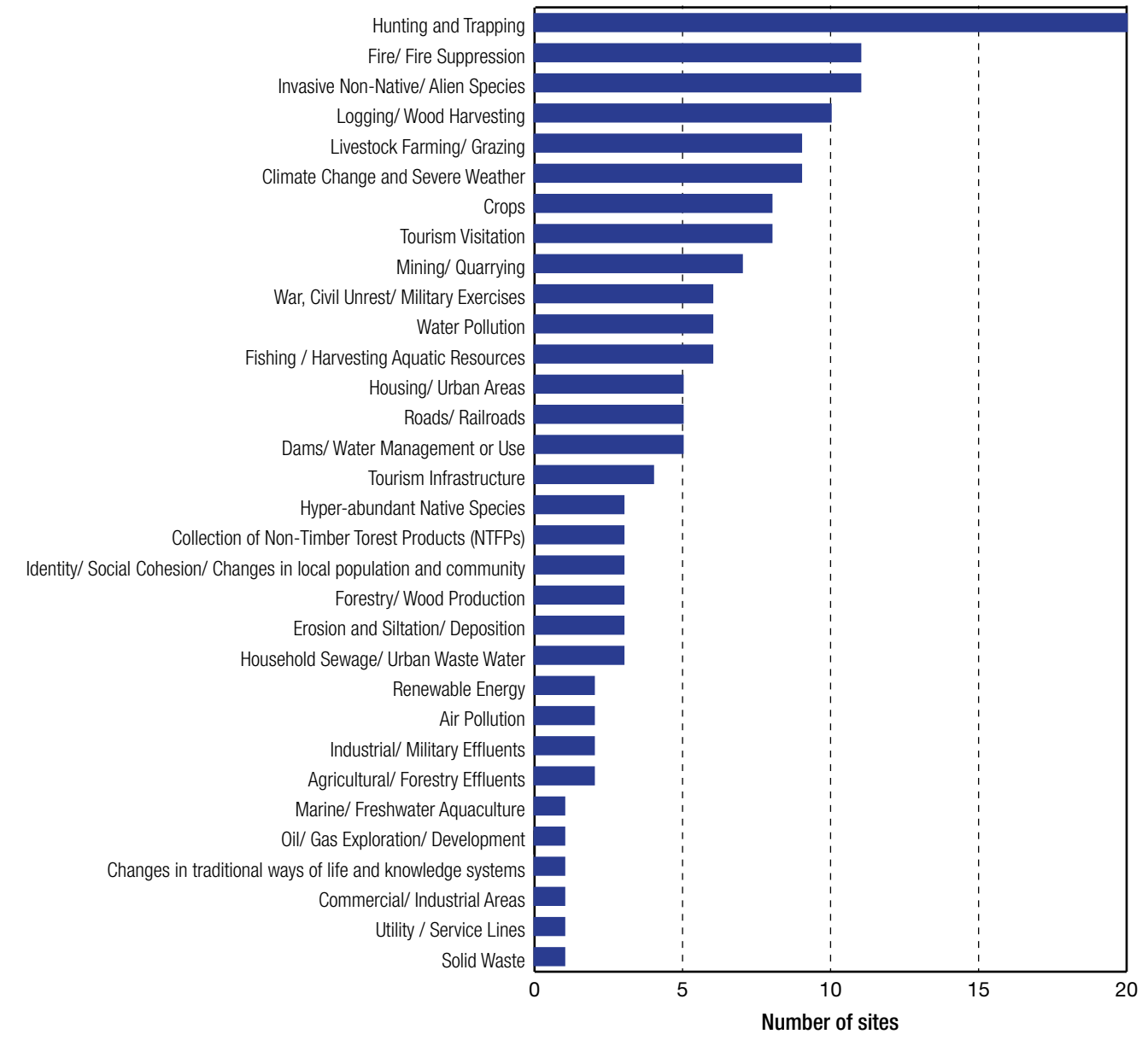

\section{Protection and management}

Around a third of the sites in Africa are assessed as effectively protected and managed with 2\% and 28\% considered as highly or mostly effective respectively. Protection and management of $47 \%$ of African World Heritage sites are found to be of some concern, while $23 \%$ are of serious concern in this regard.

2020 results for protection and management, \% of all sites in the region

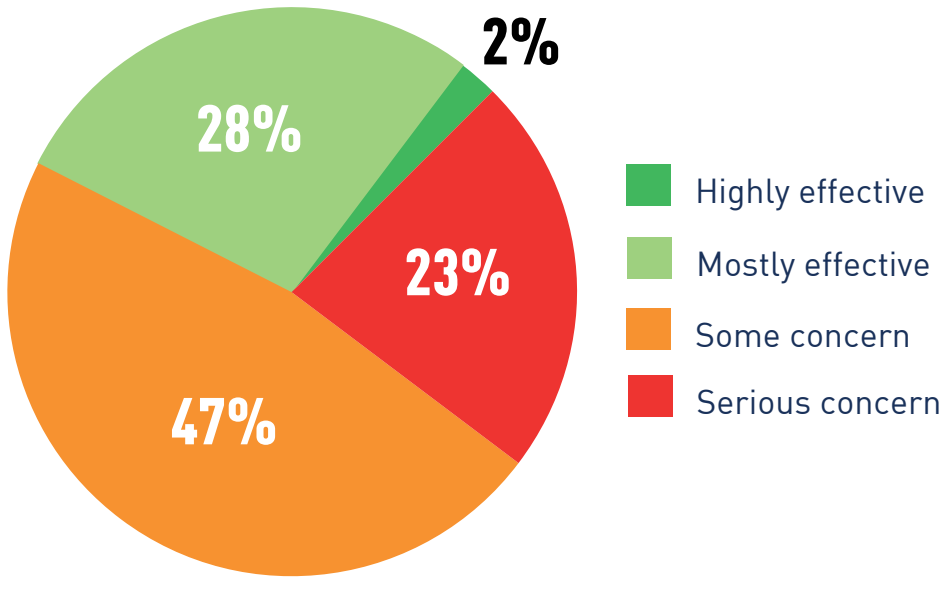




$\begin{array}{ll}41 & \text { Aldabra Atoll, Seychelles } \\ 29 & * \quad \text { Barberton Makhonjwa Mountains, South Africa } \\ 26 & \quad \text { Bwindi Impenetrable National Park, Uganda } \\ 18 & \quad \text { Cape Floral Region Protected Areas, South Africa } \\ 5 & \text { Comoé National Park, Côte d'Ivoire } \\ 9 & \text { Ecosystem and Relict Cultural Landscape of Lopé-Okanda, Gabon } \\ 30 & \text { iSimangaliso Wetland Park, South Africa } \\ 36 & \text { Killimanjaro National Park, Tanzania } \\ 19 & \text { Mosi-oa-Tunya / Victoria Falls, Zambia, Zimbabwe } \\ 37 & \text { Mount Kenya National Park/Natural Forest, Kenya } \\ 33 & \text { Ngorongoro Conservation Area, Tanzania } \\ 17 & \text { Okavango Delta, Botswana } \\ 28 & \text { Rwenzori Mountains National Park, Uganda } \\ 4 & \text { Taï National Park, Côte d'Ivoire } \\ 40 & \text { Tsingy de Bemaraha Strict Nature Reserve, Madagascar } \\ 43 & \text { Vallée de Mai Nature Reserve, Seychelles }\end{array}$

\section{GOOD WITH SOME CONCERNS}

\section{$6 \quad$ Cliff of Bandiagara (Land of the Dogons), Mali}

1 Djoudj National Bird Sanctuary, Senegal

$16 \quad$ Ennedi Massif: Natural and Cultural Landscape, Chad

$34 \quad \nabla \quad$ Kenya Lake System in the Great Rift Valley, Kenya

$32 \quad$ Lake Malawi National Park, Malawi

$25 \quad$ Maloti-Drakensberg Park, Lesotho, South Africa

$27 \quad$ Mana Pools National Park, Sapi and Chewore Safari Areas, Zimbabwe

42 Rainforests of the Atsinanana, Madagascar

12 Sangha Trinational, Cameroon, Central African Republic, Congo

$31 \quad \nabla \quad$ Serengeti National Park, Tanzania

$39 \quad$ Simien National Park, Ethiopia

$20 \quad$ Vredefort Dome, South Africa

$7 \quad$ W-Arly-Pendjari Complex, Benin, Burkina Faso, Niger

Airr and Ténéré Natural Reserves, Niger

Dja Faunal Reserve, Cameroon

Garamba National Park, Democratic Republic of the Congo

Kahuzi-Biéga National Park, Democratic Republic of the Congo 
IUCN WORLD HERITAGE OUTLOOK 3

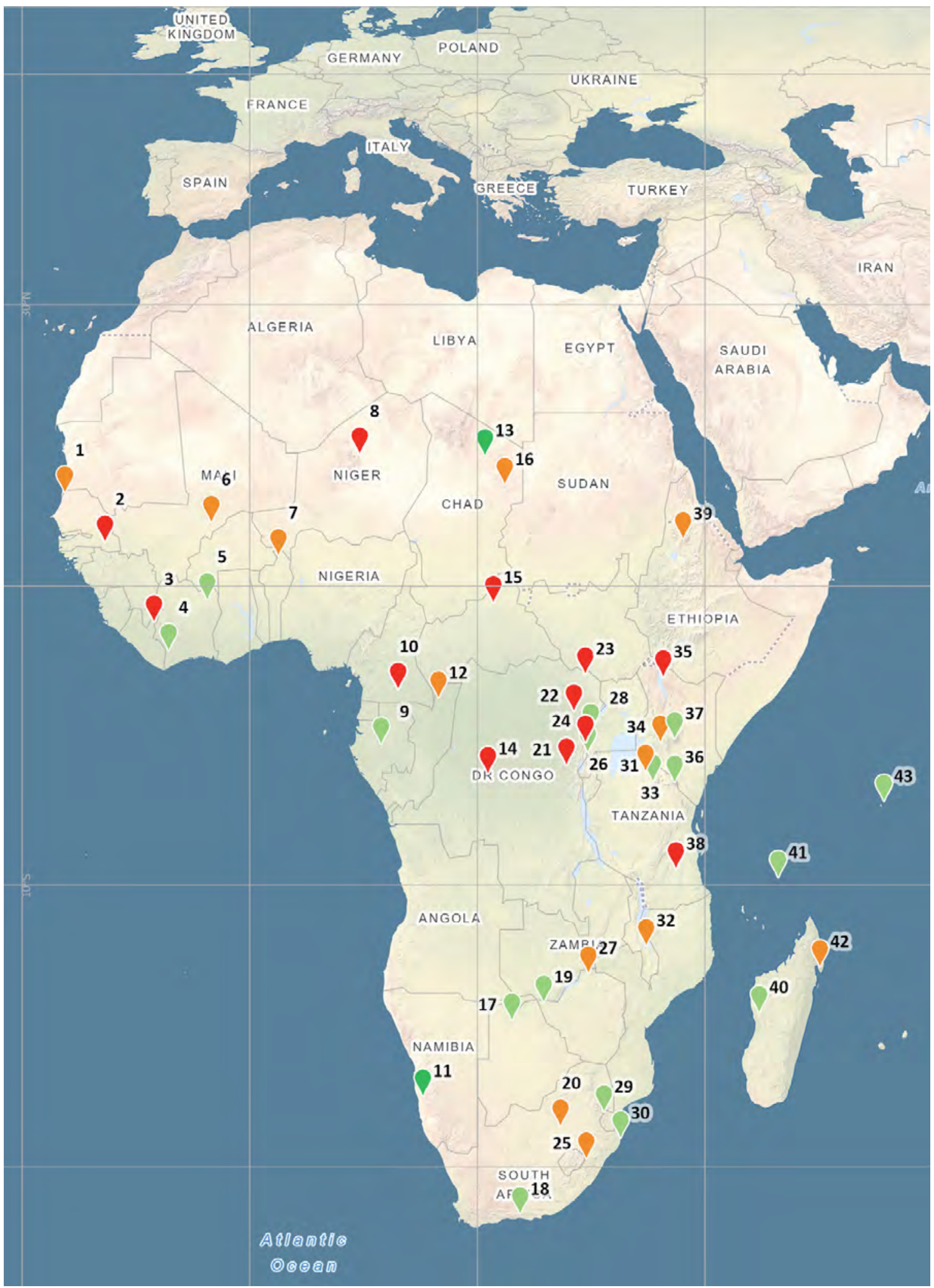




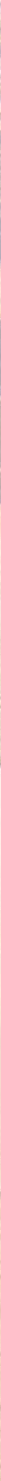


Results of the IUCN World Heritage Outlook 3 show that, of all natural World Heritage sites in the Arab States (total of eight sites), for one site (12.5\%) the conservation outlook is "good", for 37.5\% the conservation outlook is "good with some concerns" and a further 50\% of the sites are assessed as "significant concern".

Conservation Outlook 2020 for natural World Heritage in the Arab States

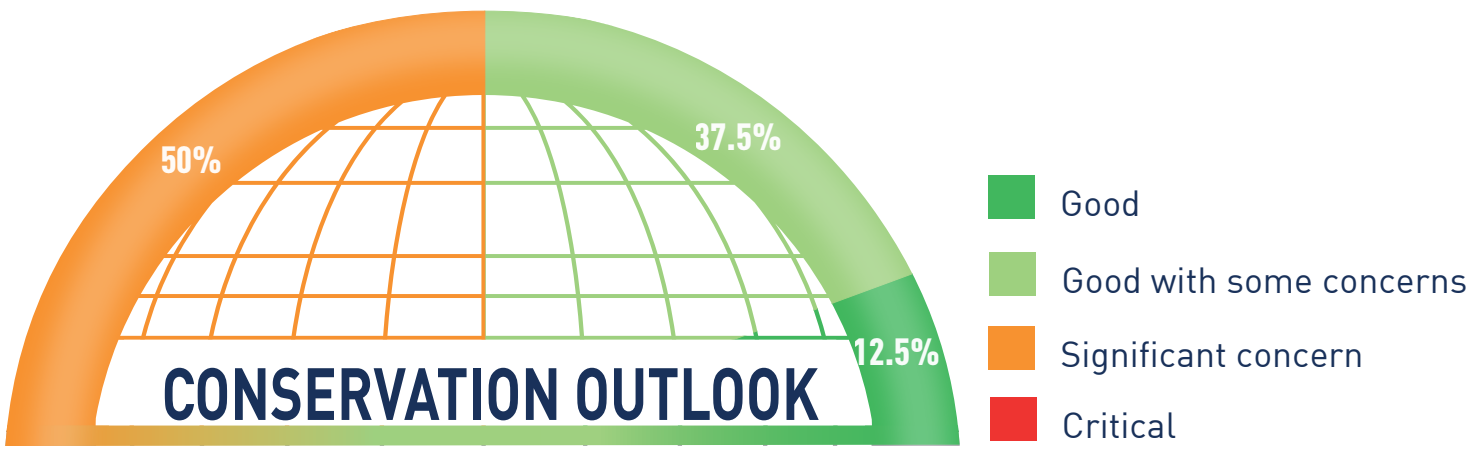

No new sites were inscribed since 2018.

Of the sites that were inscribed in 2017 or earlier, and therefore already assessed in the IUCN World Heritage Outlook 2017, two sites' conservation outlook has changed since 2017, with Wadi Al-Hitan (Whale Valley) improving from "good with some concerns" to "good" (see text box on page 10 for more details), while lchkeul National Park deteriorated from "good with concerns" to "significant concern".

\begin{tabular}{llll} 
Site & Country & Conservation Outlook 2017 & Conservation Outlook 2020 \\
\hline Ichkeul National Park & Tunisia & Good with some concerns & Significant concern \\
\hline Wadi Al-Hitan (Whale Valley) & Egypt & Good with some concerns & Good \\
\hline
\end{tabular}


IUCN WORLD HERITAGE OUTLOOK 3

\section{Threats}

Climate change and solid waste are the most prevalent current threats to natural World Heritage sites in Arab States, assessed as high or very high, followed by threats associated with impacts from tourism, fishing and water pollution. Some changes were observed compared to 2017, with solid waste (particularly linked to plastic pollution in marine areas) emerging as a more prominent threat.

Current threats assessed as high or very high in 2020. Figures are based on the number of sites where these threats occur

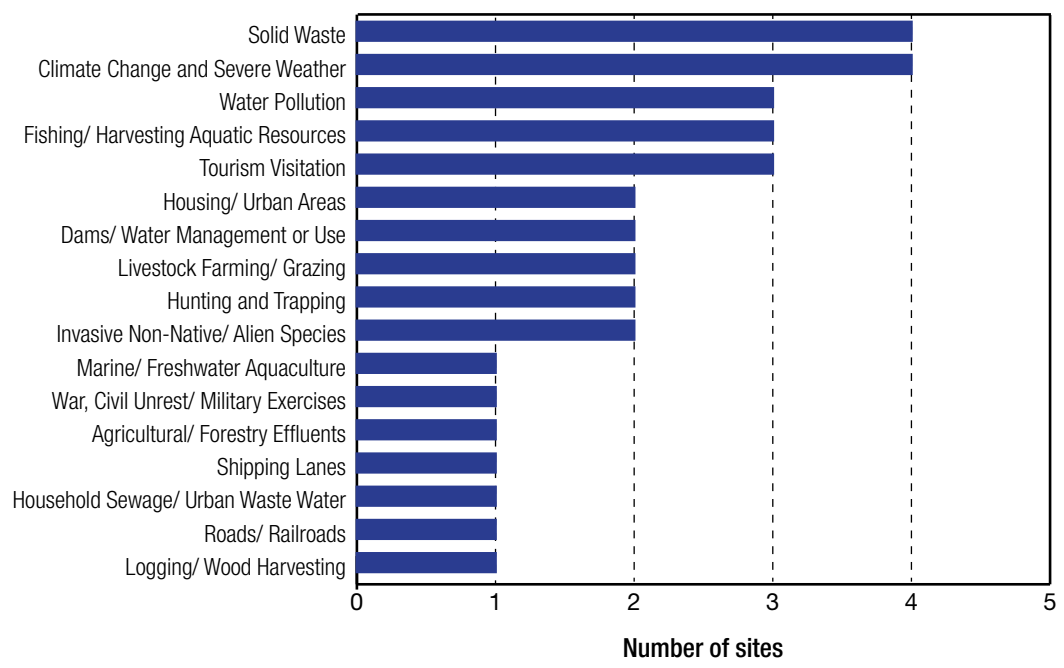

\section{Protection and management}

Only one site in the Arab States is assessed as mostly effective in protection and management (Wadi Al-Hitan in Egypt - see box on page 10), representing $12.5 \%$ of the eight sites in the region. In $75 \%$ of sites, protection and management were assessed as of some concern, while in one site (12.5\%) they were assessed of serious concern.

2020 results for protection and management, \% of all sites in the region

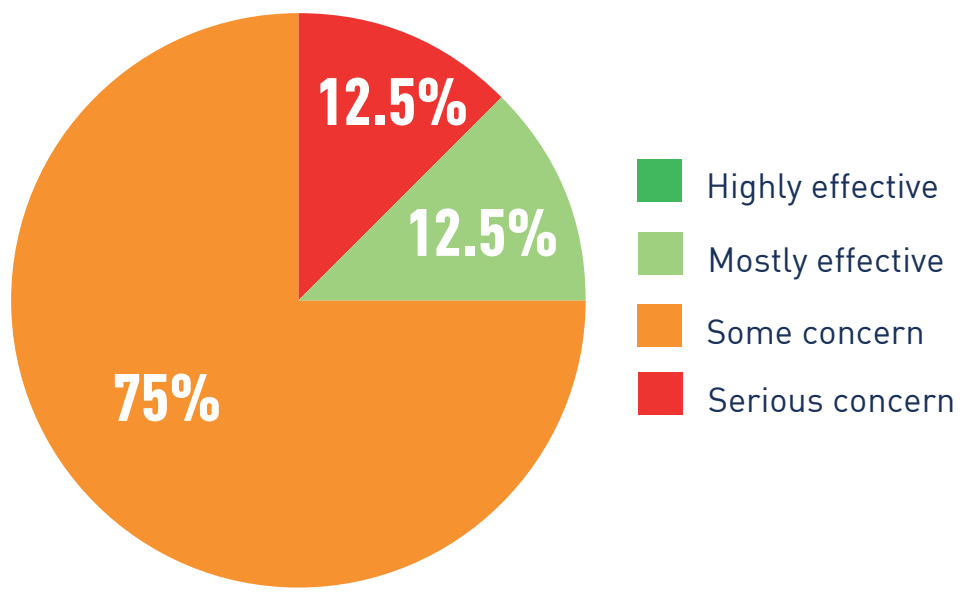




\section{Map marker Site}

4

$\Delta \quad$ Wadi Al-Hitan (Whale Valley), Egypt

GOOD

6 Sanganeb Marine National Park and Dungonab Bay - Mukkawar Island Marine National Park, Sudan

$2 \quad$ Tassili n'Ajjer, Algeria

$5 \quad$ Wadi Rum Protected Area, Jordan

\section{GOOD WITH SOME CONCERNS}

1 Banc d'Arguin National Park, Mauritania

$3 \quad$ Ichkeul National Park, Tunisia

$8 \quad$ Socotra Archipelago, Yemen

7 The Ahwar of Southern Iraq: Refuge of Biodiversity and the Relict Landscape of the Mesopotamian Cities, Iraq

\section{SIGNIFICANT CONCERN}

No sites

CRITICAL

$\Delta$ The conservation outlook improved since $2017 \quad \nabla$ The conservation outlook deteriorated since 2017 * New site inscribed on the World Heritage List since 2018 


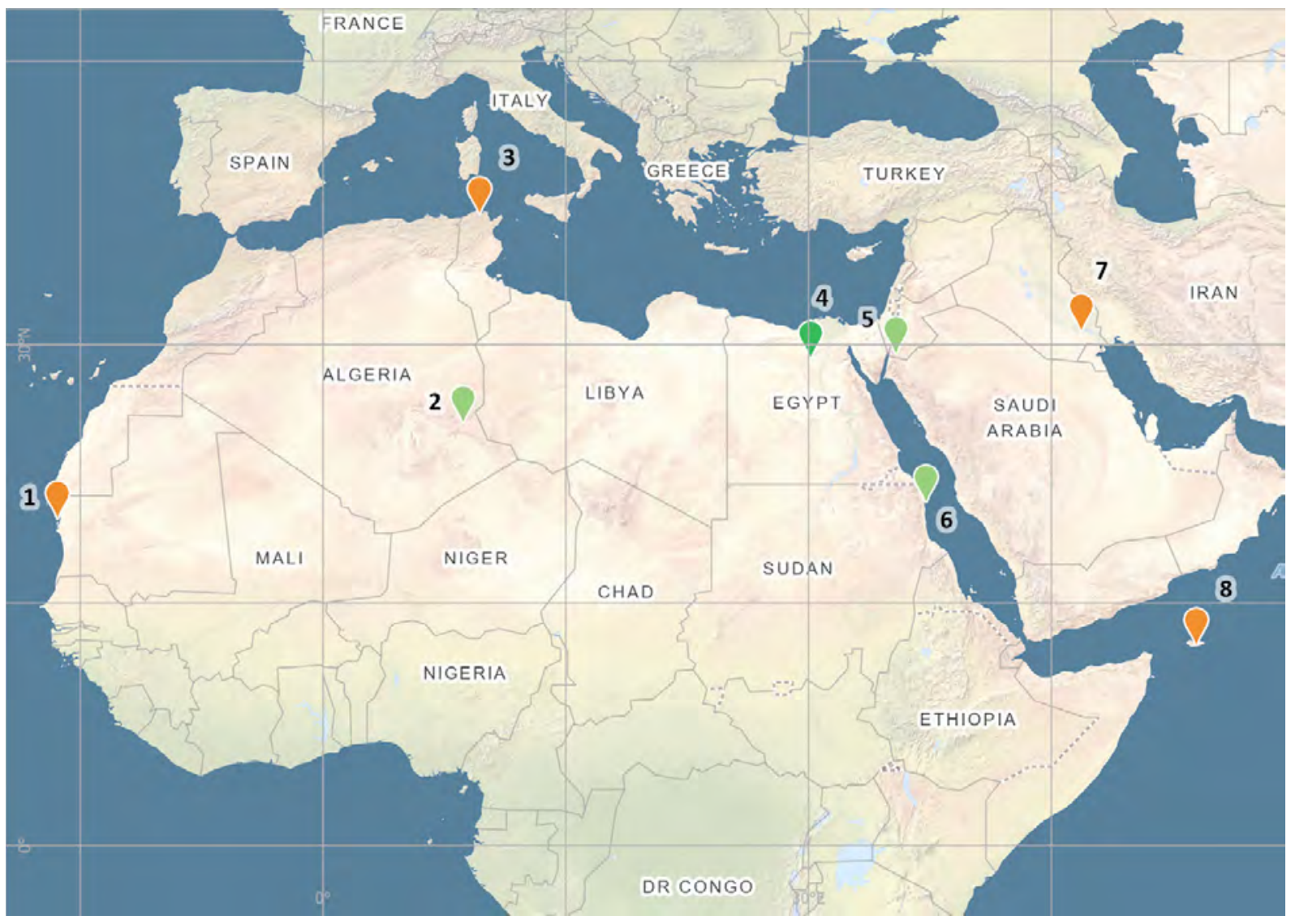





\section{Facts and figures: Asia}

* 51 natural and 6 mixed World Heritage sites in 19 countries

* 25,578,592 hectares in total

* 9 marine and coastal sites

* 3 transnational sites

* 1 site listed as "in danger"

* 3 new sites since 2018 
Results of the IUCN World Heritage Outlook 3 show that, of all natural World Heritage sites in Asia (total of 57 sites), the conservation outlook is "good" for 18\%, and "good with some concerns" for a further 54\%. For $26 \%$ of the sites, the conservation outlook is of "significant concern", and for one site (2\%) the conservation outlook is assessed as "critical".

Conservation Outlook 2020 for natural World Heritage in Asia

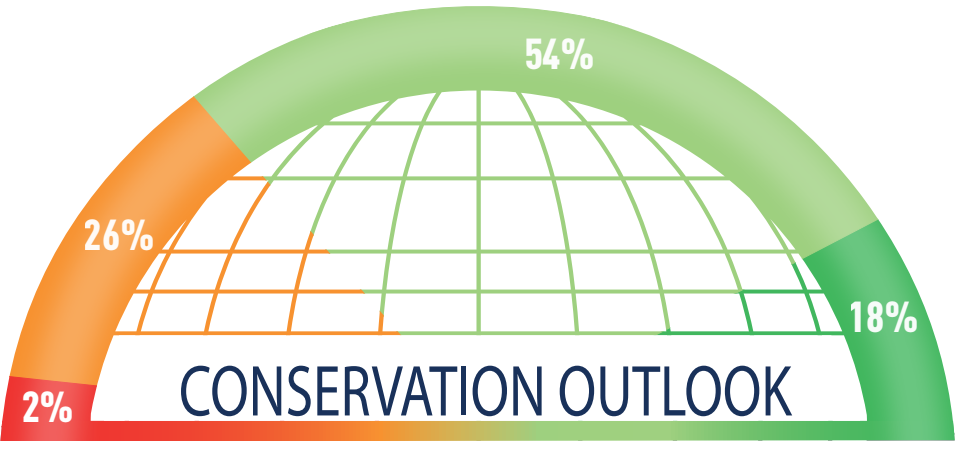

Good

Good with some concerns

Significant concern

\section{Critical}

Three new sites have been inscribed in Asia since 2018:

\begin{tabular}{llll} 
Site & Country & Conservation Outlook 2020 & Inscription year \\
\hline Fanjingshan & China & Good with some concerns & 2018 \\
\hline Hyrcanian Forests & Iran & Significant concern & 2019 \\
\hline $\begin{array}{l}\text { Migratory Bird Sanctuaries along } \\
\text { the Coast of Yellow Sea-Bohai Gulf } \\
\text { of China (Phase I) }\end{array}$ & China & Significant concern & 2019 \\
\hline
\end{tabular}

Of the sites that were inscribed in 2017 or earlier, and therefore already assessed in the IUCN World Heritage Outlook 2017, five have changed conservation outlook since 2017. Two sites have an improved conservation outlook, while for three sites the conservation outlook has deteriorated.

\begin{tabular}{llll} 
Site & Country & Conservation Outlook 2017 & Conservation Outlook 2020 \\
\hline Central Highlands of Sri Lanka & Sri Lanka & Good with some concerns & Significant concern \\
\hline Gunung Mulu National Park & Malaysia & Good & Good with some concerns \\
\hline Phong Nha-Ke Bang National Park & Viet Nam & Good with some concerns & Significant concern \\
\hline Trang An Landscape Complex & Viet Nam & Significant concern & Good with some concerns \\
\hline $\begin{array}{l}\text { Wulingyuan Scenic and Historic } \\
\text { Interest Area }\end{array}$ & China & Significant concern & Good with some concerns \\
\hline
\end{tabular}

\section{Threats}

The most prevalent current threats to World Heritage sites in Asia assessed as high or very high are hunting, followed by tourism visitation and climate change. 
Current threats assessed as high or very high in 2020. Figures are based on the number of sites where these threats occur

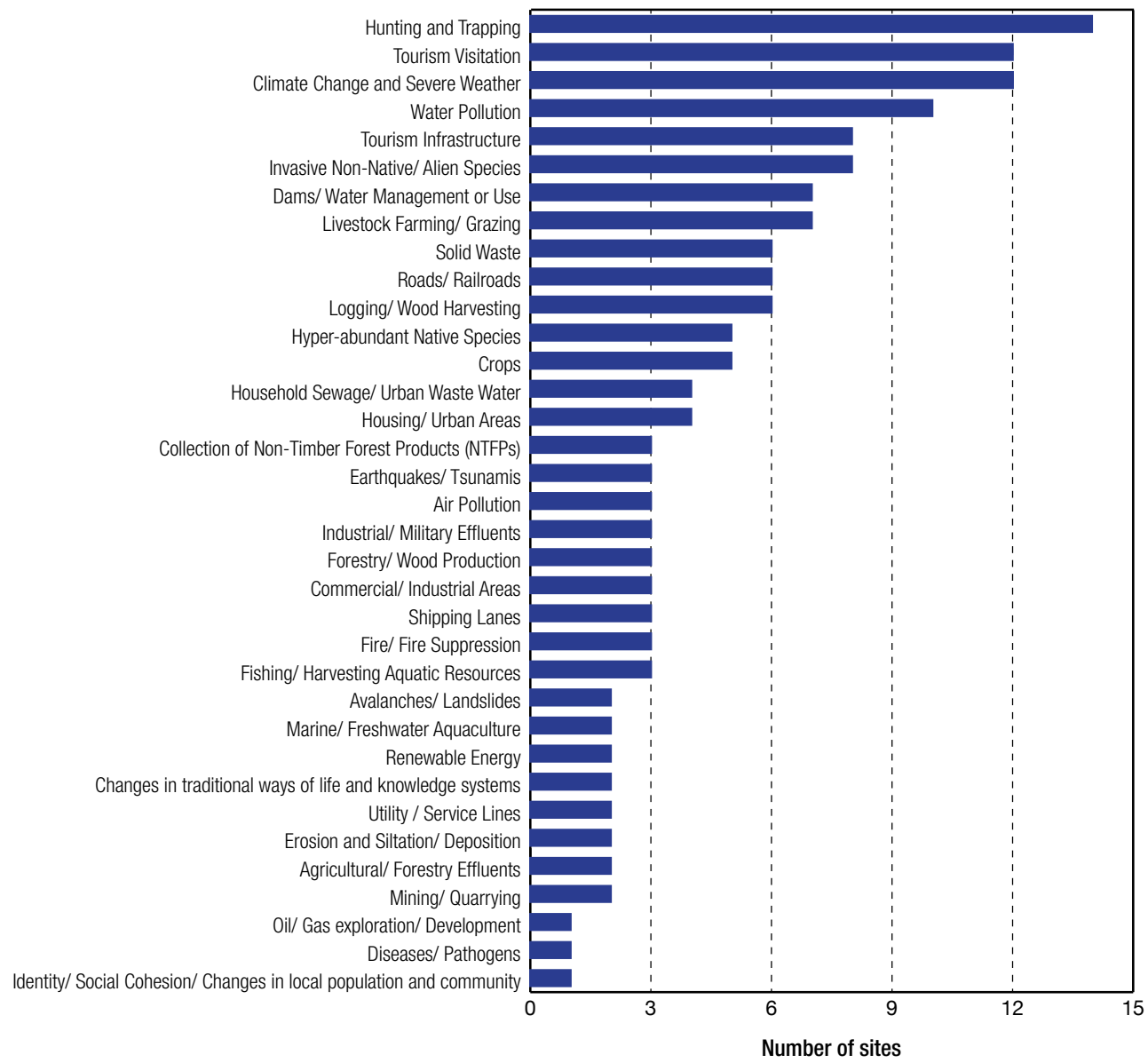

\section{Protection and management}

Over half of natural World Heritage sites in Asia are assessed as effectively protected and managed with $5 \%$ under highly effective, and a further $48 \%$ under mostly effective protection and management. In $43 \%$ of sites in Asia, protection and management are of some concern and in $4 \%$ of serious concem. This represents some improvement compared to the 2017 results with both the percentage of sites assessed as having effective management increasing and a decrease in the number of sites where protection and management were assessed as of serious concem.

2020 results for protection and management, \% of all sites in the region

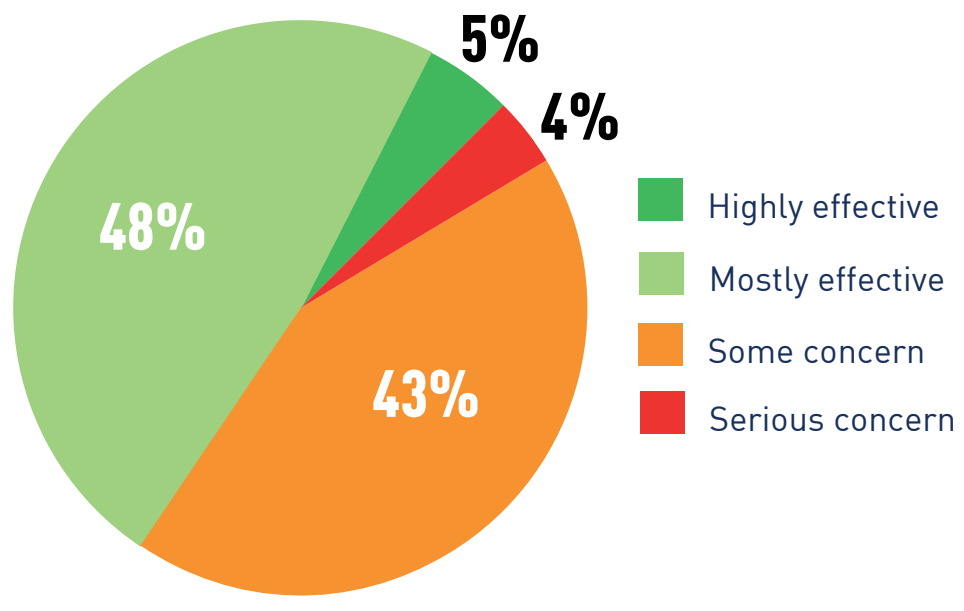




$\begin{array}{ll}\text { Map Marker } & \text { Site } \\ 27 & \text { Chengjiang Fossil Site, China } \\ 33 & \text { China Danxia, China } \\ 52 & \text { Jeju Volcanic Island and Lava Tubes, Republic of Korea } \\ 15 & \text { Khangchendzonga National Park, India } \\ 2 & \text { Lut Desert, Iran } \\ 28 & \text { Mount Emei Scenic Area, including Leshan Giant Buddha Scenic Area, China } \\ 51 & \text { Mount Hamiguitan Range Wildlife Sanctuary, Philippines } \\ 46 & \text { Mount Huangshan, China } \\ 45 & \text { Mount Sanqingshan National Park, China } \\ 55 & \text { Shirakami-Sanchi, Japan }\end{array}$

GOOD

\begin{tabular}{|c|c|c|}
\hline 36 & * & Fanjingshan, China \\
\hline 8 & & Great Himalayan National Park Conservation Area, India \\
\hline 41 & $\nabla$ & Gunung Mulu National Park, Malaysia \\
\hline 35 & & Ha Long Bay, Viet Nam \\
\hline 30 & & Huanglong Scenic and Historic Interest Area, China \\
\hline 37 & & Hubei Shennongjia, China \\
\hline 29 & & Jiuzhaigou Valley Scenic and Historic Interest Area, China \\
\hline 21 & & Kaziranga National Park, India \\
\hline 7 & & Keoladeo National Park, India \\
\hline 42 & & Kinabalu Park, Malaysia \\
\hline 40 & & Landscapes of Dauria, Mongolia, Russian Federation \\
\hline 43 & & Mount Taishan, China \\
\hline 44 & & Mount Wuyi, China \\
\hline 9 & & Nanda Devi and Valley of Flowers National Parks, India \\
\hline 56 & & Ogasawara Islands, Japan \\
\hline 47 & & Puerto-Princesa Subterranean River National Park, Philippines \\
\hline 19 & & Qinghai Hoh Xil, China \\
\hline 3 & & Saryarka - Steppe and Lakes of Northern Kazakhstan, Kazakhstan \\
\hline 57 & & Shiretoko, Japan \\
\hline 26 & & Sichuan Giant Panda Sanctuaries - Wolong, Mount Siguniang \& Jiajin Mountains, China \\
\hline 39 & & South China Karst, China \\
\hline 16 & & Sundarbans National Park, India \\
\hline 5 & & Tajik National Park (Mountains of the Pamirs), Tajikistan \\
\hline 23 & & Thungyai-Huai Kha Khaeng Wildlife Sanctuaries, Thailand \\
\hline 32 & $\Delta$ & Trang An Landscape Complex, Viet Nam \\
\hline 49 & & Tubbataha Reefs Natural Park, Philippines \\
\hline 31 & & Ujung Kulon National Park, Indonesia \\
\hline 20 & & Uvs Nuur Basin, Mongolia, Russian Federation \\
\hline 38 & $\Delta$ & Wulingyuan Scenic and Historic Interest Area, China \\
\hline $\begin{array}{l}10 \\
53\end{array}$ & & $\begin{array}{l}\text { Xinjiang Tianshan, China } \\
\text { Yakushima. Japan }\end{array}$ \\
\hline
\end{tabular}

$12 \quad$ Central Highlands of Sri Lanka, Sri Lanka

$13 \quad$ Chitwan National Park, Nepal

$25 \quad$ Dong Phayayen-Khao Yai Forest Complex, Thailand

$1 \quad \star \quad$ Hyrcanian Forests, Iran

$48 \quad$ Komodo National Park, Indonesia

$54 \quad$ Lorentz National Park, Indonesia

$18 \quad$ Manas Wild life Sanctuary, India

$50 \quad * \quad$ Migratory Bird Sanctuaries along the Coast of Yellow Sea-Bohai Gulf of China (Phase I), China

$34 \quad \nabla \quad$ Phong Nha-Ke Bang National Park, Viet Nam

$14 \quad$ Sagarmatha National Park, Nepal

$11 \quad$ Sinharaja Forest Reserve, Sri Lanka

17 The Sundarbans, Bangladesh

22 Three Parallel Rivers of Yunnan Protected Areas, China

$6 \quad$ Western Ghats, India

$4 \quad$ Western Tien-Shan, Kazakhstan, Kyrgyzstan, Uzbekistan

\section{SIGNIFICANT CONCERN}




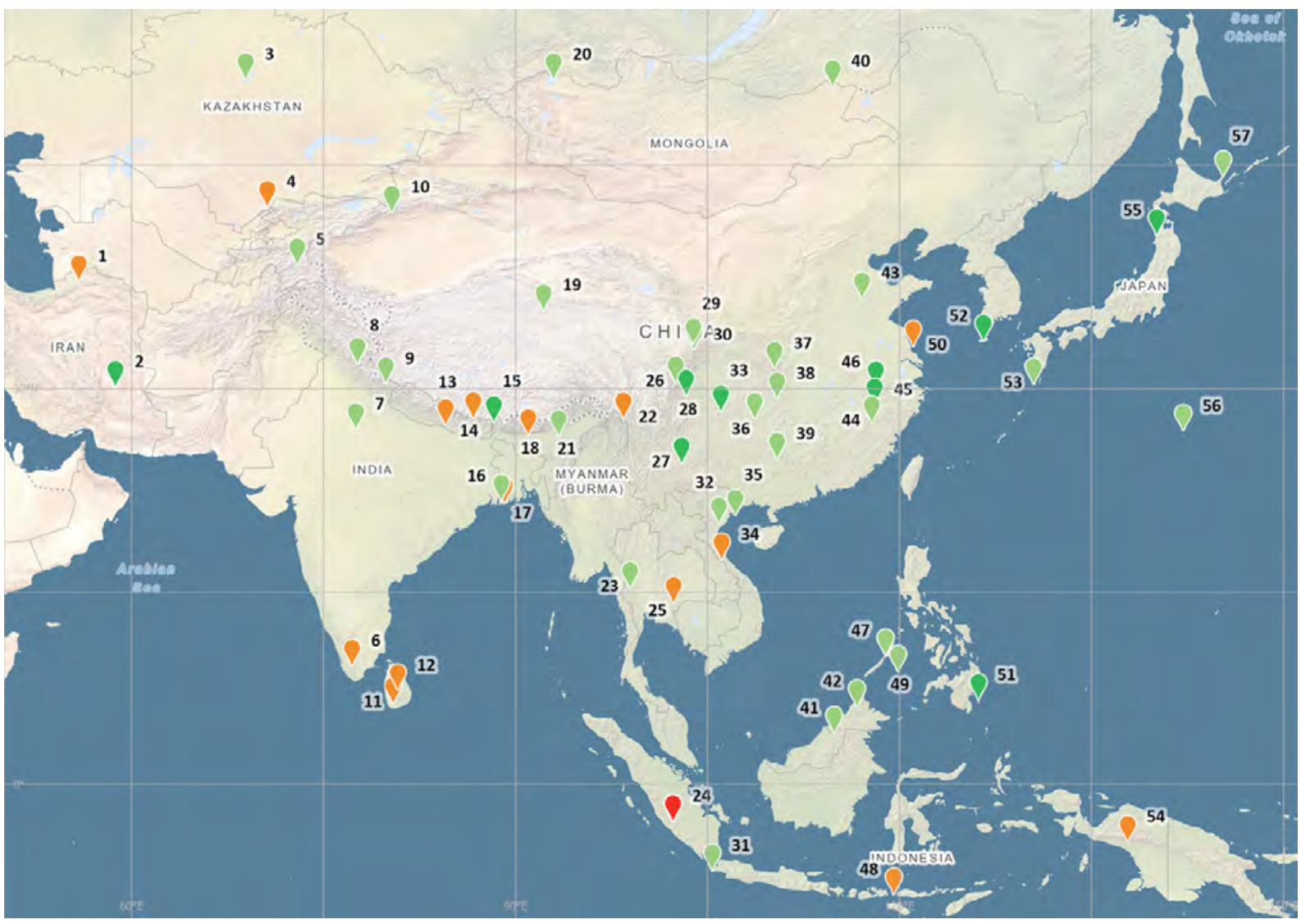


IUCN

\section{Regional Outlook:} Oceania 


\section{Facts and figures: Oceania}

* 16 natural and 6 mixed World Heritage sites in 5 countries

* 90,691,672 hectares in total

* 10 marine and coastal sites

* 0 transnational sites

* 1 site listed as "in danger"

* 0 new sites since 2018

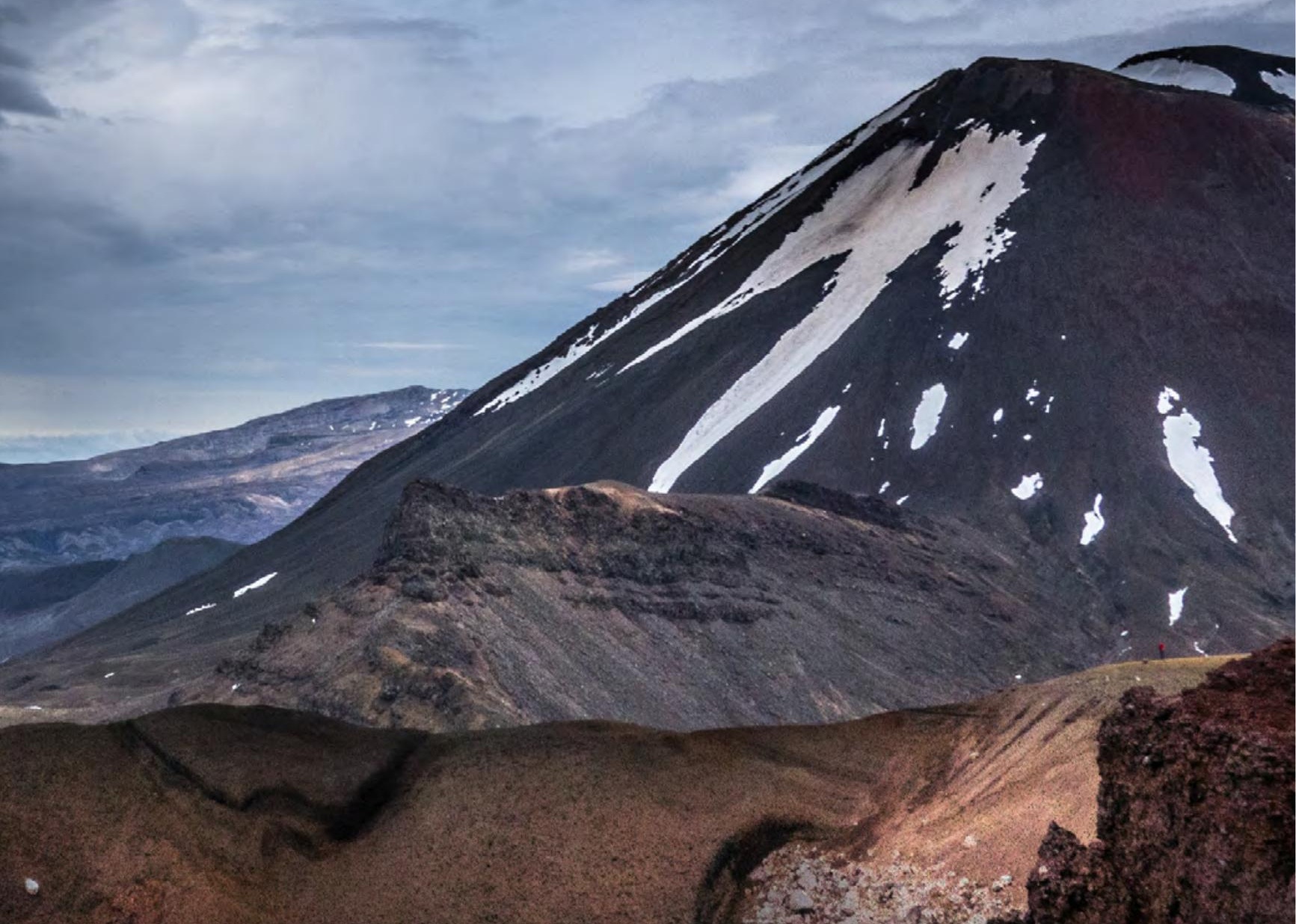


Results of the IUCN World Heritage Outlook 3 show that, of all natural World Heritage sites in Oceania (total of 22 sites), the conservation outlook is "good" for 36.5\%, and "good with some concerns" for a further 36.5\%. For 18\% of the sites, the conservation outlook is of "significant concern", and for two sites (9\%) the conservation outlook is assessed as "critical".

Conservation Outlook 2020 for natural World Heritage sites in Oceania

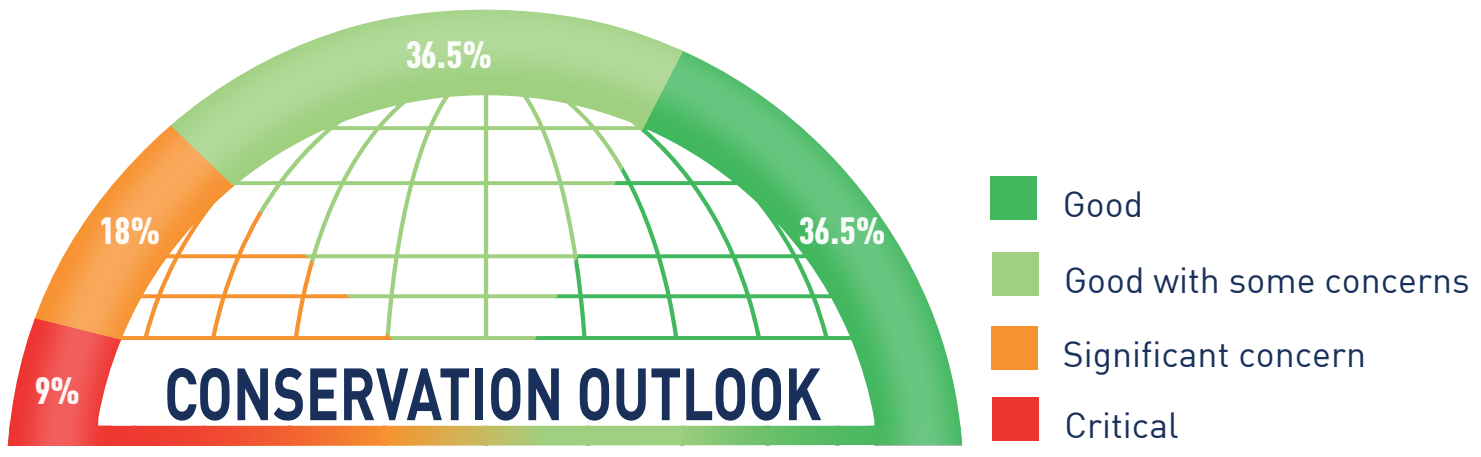

No new sites were inscribed in Oceania since 2018

Of the sites that were inscribed in 2017 or earlier, and therefore already assessed in the IUCN World Heritage Outlook 2017, five sites deteriorated: two from "good" to "good with some concerns", two from "good with some concerns" to "significant concern" and one from "significant concern" to "critical". No sites in Oceania have improved their conservation outlook since 2017.

\begin{tabular}{llll} 
Site & Country & Conservation Outlook 2017 & Conservation Outlook 2020 \\
\hline Gondwana Rainforests of Australia & Australia & Good with some concerns & Significant concern \\
\hline Greater Blue Mountains Area & Australia & Good with some concerns & Significant concern \\
\hline Great Barrier Reef & Australia & Significant concern & Critical \\
\hline Ningaloo Coast & Australia & Good & Good with some concerns \\
\hline Shark Bay, Western Australia & Australia & Good & Good with some concerns \\
\hline
\end{tabular}


IUCN WORLD HERITAGE OUTLOOK 3

\section{Threats}

In Oceania, by far the most prevalent current threats to natural World Heritage sites are invasive alien species and climate change which affect a disproportionately large number of sites.

Current threats assessed as high or very high in 2020. Figures are based on the number of sites where these threats occur

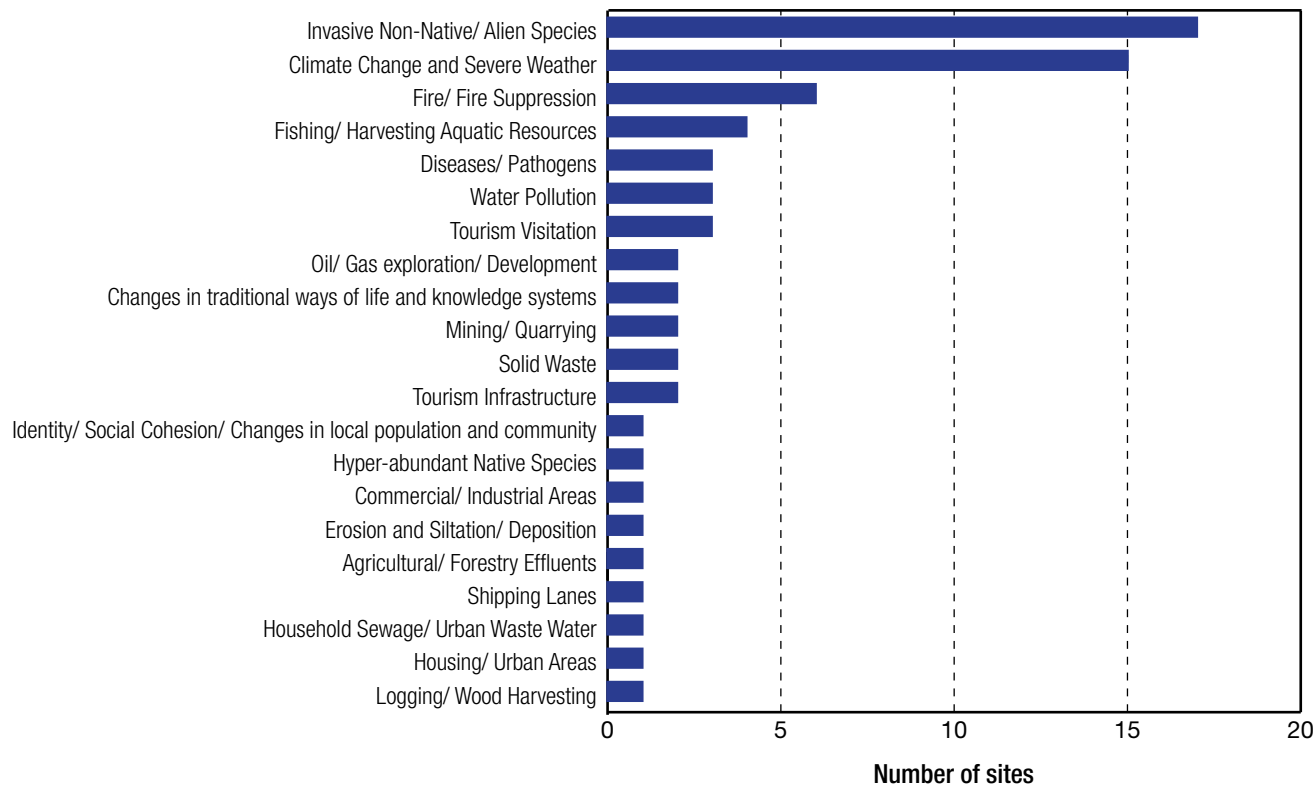

\section{Protection and management}

Overall, the vast majority of natural World Heritage sites in Oceania benefit from effective protection and management with 32\% of sites assessed as highly effective and 64\% of site assessed as mostly effective. However one site, representing 4\% of the total sites in Oceania, is of serious concern in this regard - as in 2017, this site is East Rennell in the Solomon Islands, which continues to face a number of issues related to its protection regime and management.

2020 results for protection and management, \% of all sites in the region

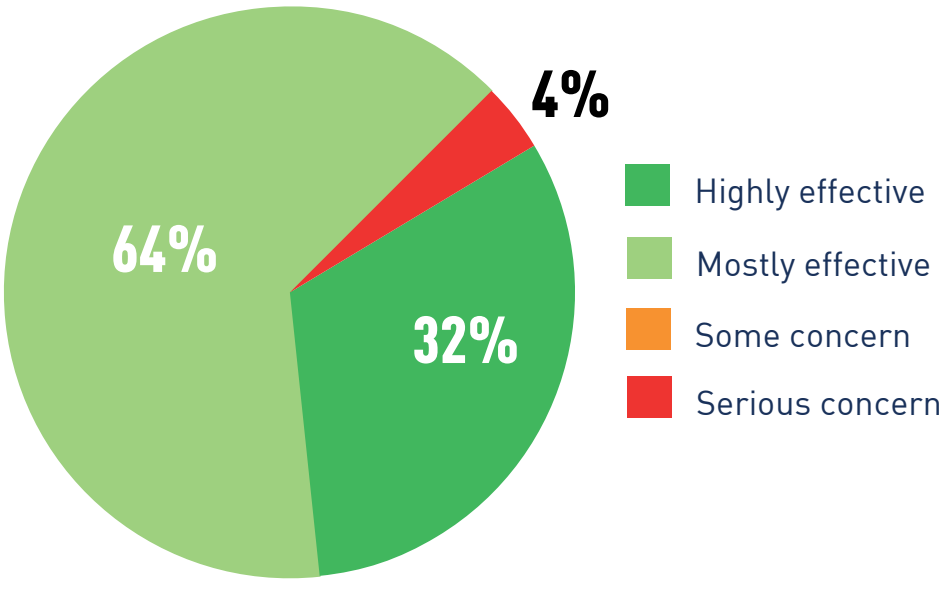




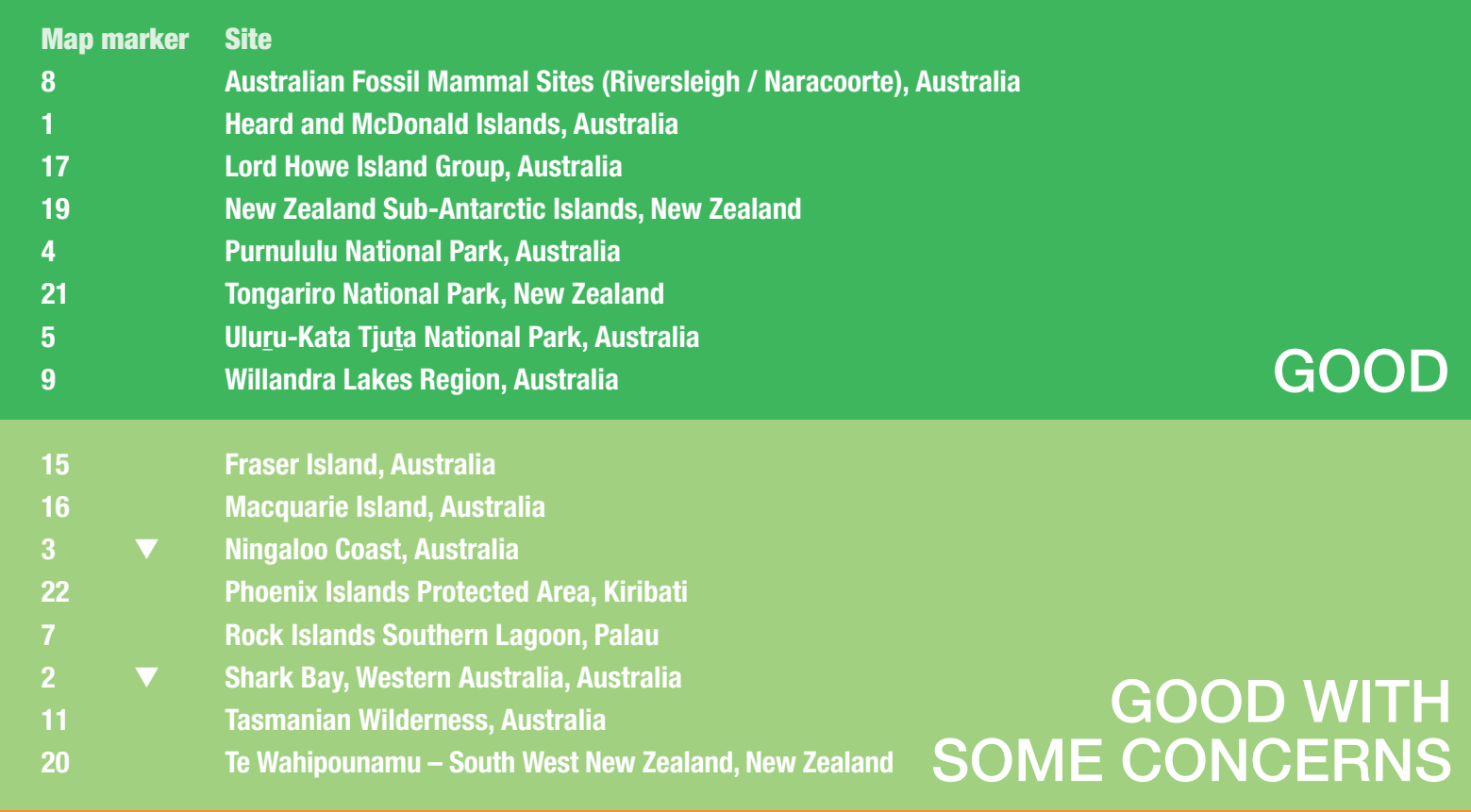

$14 \quad$ Gondwana Rainforests of Australia, Australia

$13 \quad$ Greater Blue Mountains Area, Australia

$6 \quad$ Kakadu National Park, Australia

$10 \quad$ Wet Tropics of Queensland, Australia

\section{SIGNIFICANT CONCERN}

$18 \quad$ East Rennell, Solomon Islands

$12 \quad$ Great Barrier Reef, Australia

\section{CRITICAL}

$\Delta$ The conservation outlook improved since $2017 \quad \nabla$ The conservation outlook deteriorated since 2017

* New site inscribed on the World Heritage List since 2018 
IUCN WORLD HERITAGE OUTLOOK 3

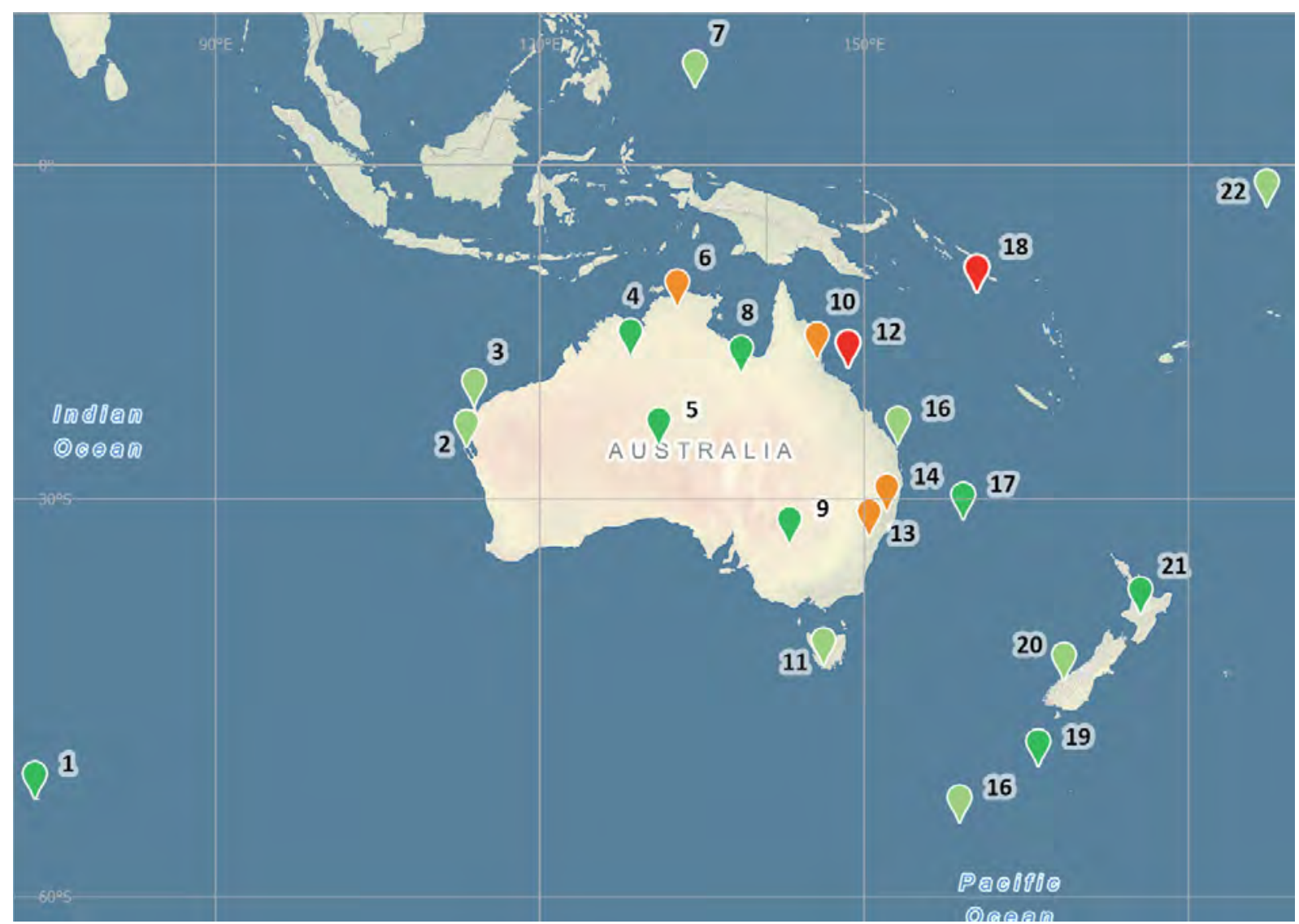




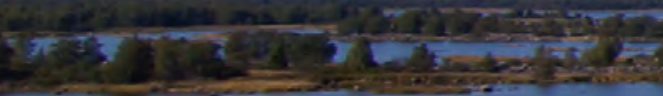

\section{Regional Outlook: Europe}

sen 23 


\section{Facts and figures: Europe}

* 45 natural and $\mathbf{9}$ mixed World Heritage sites in $\mathbf{3 0}$ countries

* 99,079,524 hectares in total

* 11 marine and coastal sites

* 8 transnational sites

* 0 sites listed as "in danger"

* 3 new sites since 2018

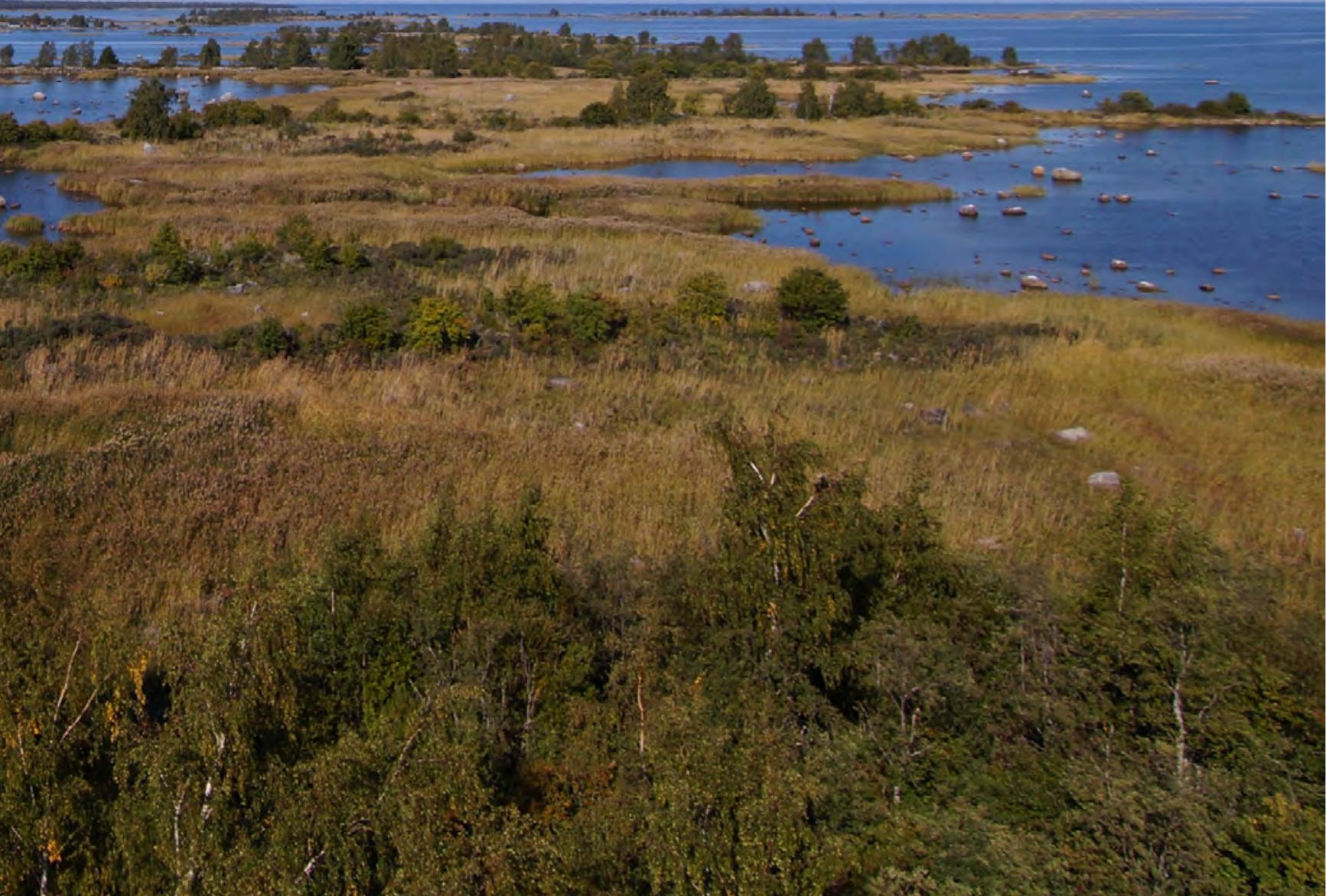


Results of the IUCN World Heritage Outlook 3 show that, of all natural and mixed World Heritage sites in Europe (total of 54 sites), for one-third (33.5\%) the conservation outlook is "good", for just over one-third (35\%) the conservation outlook is "good with some concerns" and for just under one-third (31.5\% ) the conservation outlook is assessed as "significant concern". There are no sites in Europe for which the conservation outlook is assessed as "critical".

Conservation Outlook 2020 for natural World Heritage in Europe

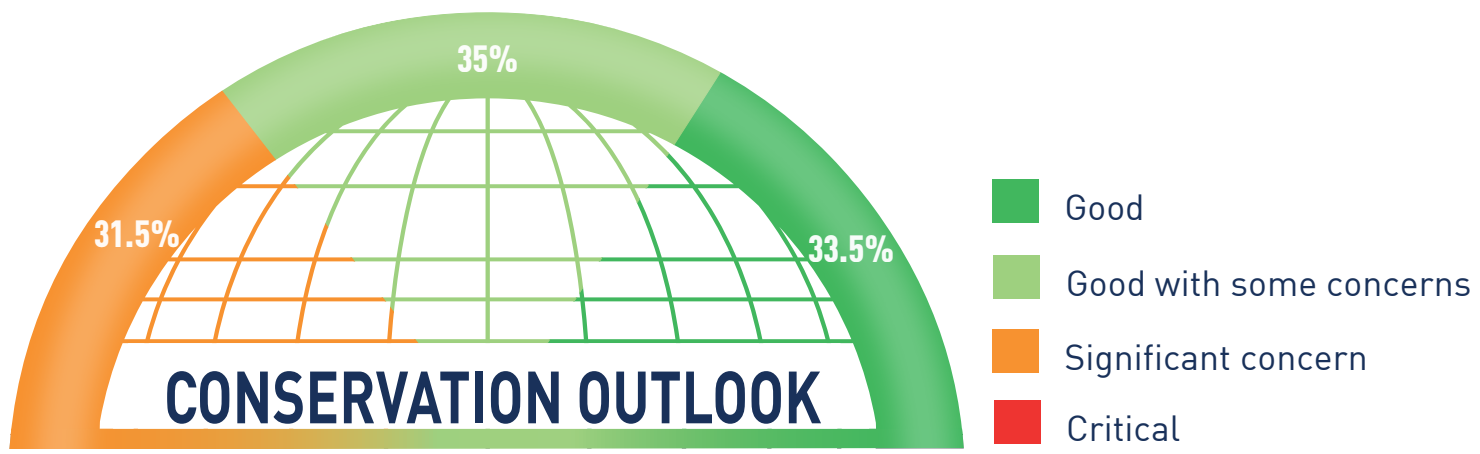

Three new sites have been inscribed in Europe since 2018:

\begin{tabular}{llll} 
Site & Country & Conservation Outlook 2020 & Inscription year \\
\hline $\begin{array}{l}\text { Chaîne des Puys - Limagne fault } \\
\text { tectonic arena }\end{array}$ & France & Good with some concerns & 2018 \\
\hline French Austral Lands and Seas & France & Good & 2019 \\
\hline $\begin{array}{l}\text { Vatnajökull National Park - } \\
\text { Dynamic Nature of Fire and Ice }\end{array}$ & Iceland & Good & 2019 \\
\hline
\end{tabular}

In addition to these three inscriptions, the Natural and Cultural Heritage of the Ohrid Region site was extended into Albania, while the Central Sikhote-Alin site underwent a major extension.

Of the sites that were inscribed in 2017 or earlier, and therefore already assessed in the IUCN World Heritage Outlook 2017, two sites, Laurisilva of Madeira (Portugal) and Giant's Causeway and Causeway Coast (UK), improved their conservation outlook from "significant concern" to "good with some concerns".

\begin{tabular}{llll} 
Site & Country & Conservation Outlook 2017 & Conservation Outlook 2020 \\
\hline $\begin{array}{l}\text { Giant's Causeway and Causeway } \\
\text { Coast }\end{array}$ & UK & Significant concern & Good with some concerns \\
\hline Laurisilva of Madeira & Portugal & Significant concern & Good with some concerns \\
\hline
\end{tabular}


IUCN WORLD HERITAGE OUTLOOK 3

\section{Threats}

The most prevalent current threats to European World Heritage sites are climate change, invasive alien species and impacts from tourism and visitation.

Current threats assessed as high or very high in 2020. Figures are based on the number of sites where these threats occur

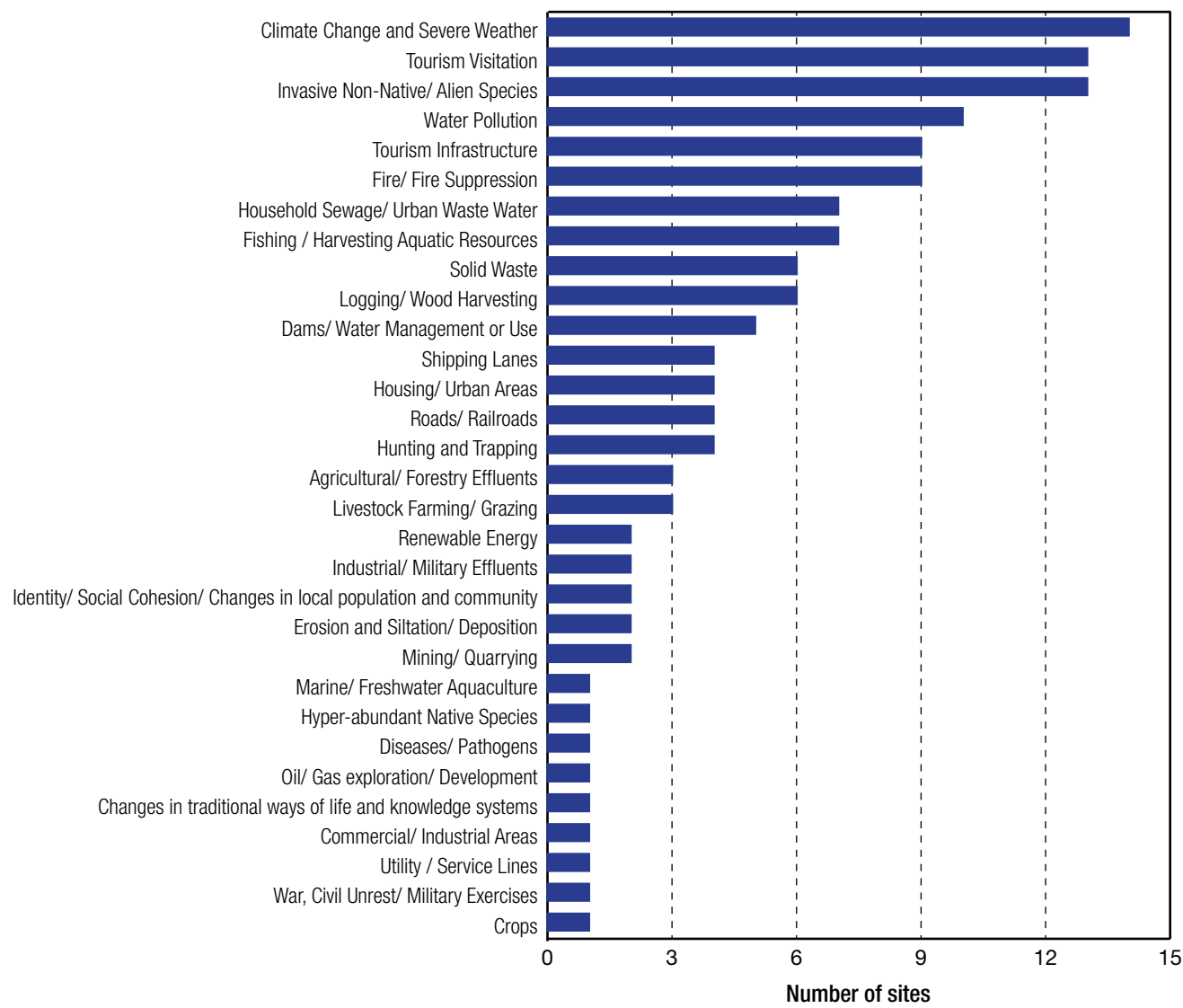

\section{Protection and management}

Overall, $15 \%$ of the natural World Heritage sites in Europe are highly effective in their protection and management and 39\% are mostly effective, while in 35\% protection and management are assessed as of some concern and in $11 \%$ of serious concern. This represents an improvement compared to the results from 2017, with the percentage of sites assessed as having highly or mostly effective protection and management increasing from 49\% to 54\%.

2020 results for protection and management, \% of all sites in the region

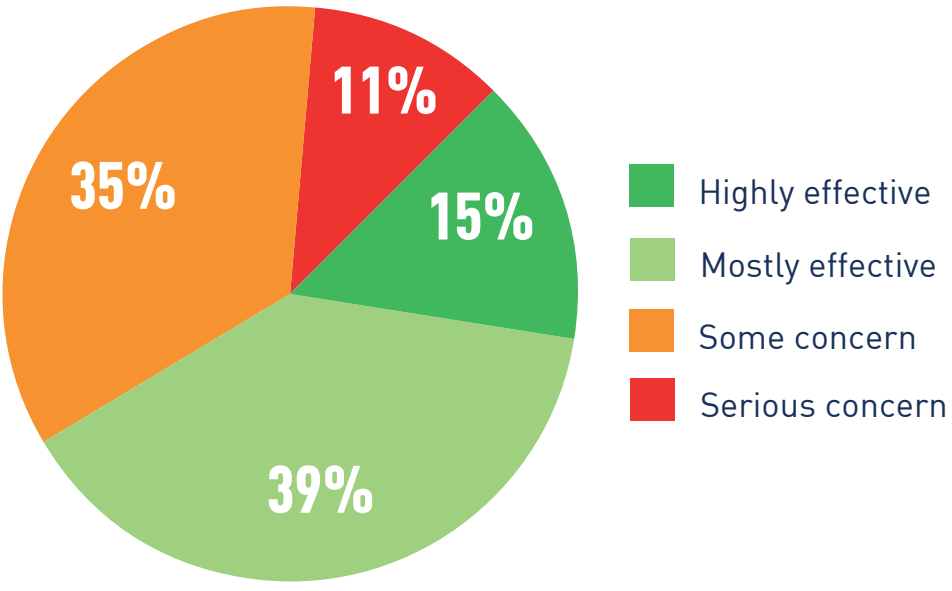




\begin{tabular}{|c|c|c|}
\hline \multicolumn{2}{|c|}{ Map marker } & Site \\
\hline 29 & & Caves of Aggtelek Karst and Slovak Karst, Hungary, Slovakia \\
\hline 10 & & Dorset and East Devon Coast, UK \\
\hline 52 & * & French Austral Lands and Seas, France \\
\hline 31 & & High Coast / Kvarken Archipelago, Finland, Sweden \\
\hline 27 & & Laponian Area, Sweden \\
\hline 46 & & Lena Pillars Nature Park, Russian Federation \\
\hline 18 & & Messel Pit Fossil Site, Germany \\
\hline 19 & & Monte San Giorgio, Italy, Switzerland \\
\hline 25 & & Mount Etna, Italy \\
\hline 44 & & Putorana Plateau, Russian Federation \\
\hline 7 & & St Kilda, UK \\
\hline 22 & & Stevns Klint, Denmark \\
\hline 2 & & Surtsey, Iceland \\
\hline 20 & & Swiss Tectonic Arena Sardona, Switzerland \\
\hline 6 & & Teide National Park, Spain \\
\hline 5 & * & Vatnajökull National Park - Dynamic Nature of Fire and Ice, Iceland \\
\hline 16 & & Wadden Sea, Denmark, Germany, Netherlands \\
\hline & & st Norwegian Fjords - Geirangerfjord and $\mathrm{N}$ \\
\hline
\end{tabular}

GOOD

$\begin{array}{ll}47 & \text { Central Sikhote-Alin, Russian Federation } \\ 13 & * \quad \text { Chaîne des Puys - Limagne fault tectonic arena, France } \\ 39 & \text { Danube Delta, Romania } \\ 8 & \text { Giant's Causeway and Causeway Coast, UK } \\ 43 & \quad \text { Golden Mountains of Altai, Russian Federation } \\ 40 & \text { Göreme National Park and the Rock Sites of Cappadocia, Turkey } \\ 17 & \text { Gulf of Porto: Calanche of Piana, Gulf of Girolata, Scandola Reserve, France } \\ 38 & \text { Hierapolis-Pamukkale, Turkey } \\ 1 & \text { Ilulissat Icefjord, Denmark } \\ 24 & \text { Isole Eolie (Aeolian Islands), Italy } \\ 53 & \text { Lagoons of New Caledonia: Reef Diversity and Associated Ecosystems, France } \\ 4 & \text { Laurisilva of Madeira, Portugal } \\ 32 & \text { Meteora, Greece } \\ 36 & \text { Mount Athos, Greece } \\ 11 & \text { Pyrénées - Mont Perdu, France, Spain }\end{array}$

$23 \quad$ Škocjan Caves, Slovenia

37 Srebarna Nature Reserve, Bulgaria

$15 \quad$ Swiss Alps Jungfrau-Aletsch, Switzerland

$21 \quad$ The Dolomites, Italy

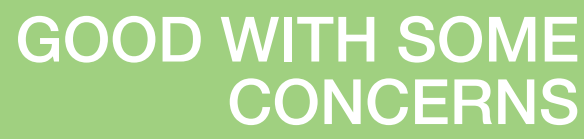

34 Ancient and Primeval Beech Forests of the Carpathians and Other Regions of Europe, Albania, Austria, Belgium, Bulgaria, Croatia, Germany, Italy, Romania, Slovakia, Slovenia, Spain, Ukraine

$35 \quad$ Białowieża Forest, Belarus, Poland

$9 \quad$ Doñana National Park, Spain

$28 \quad$ Durmitor National Park, Montenegro

$3 \quad$ Garajonay National Park, Spain

$50 \quad$ Gough and Inaccessible Islands, UK

$54 \quad$ Henderson Island, UK

$12 \quad$ lbiza: Biodiversity and Culture, Spain

$45 \quad$ Lake Baikal, Russian Federation

$30 \quad$ Natural and Cultural Heritage of the Ohrid region, Albania, North Macedonia

$49 \quad$ Natural System of Wrangel Island Reserve, Russian Federation

$33 \quad$ Pirin National Park, Bulgaria

$51 \quad$ Pitons, cirques and remparts of Reunion Island, France

$26 \quad$ Plitvice Lakes National Park, Croatia

$42 \quad$ Virgin Komi Forests, Russian Federation

$48 \quad$ Volcanoes of Kamchatka, Russian Federation

41 Western Caucasus, Russian Federation 


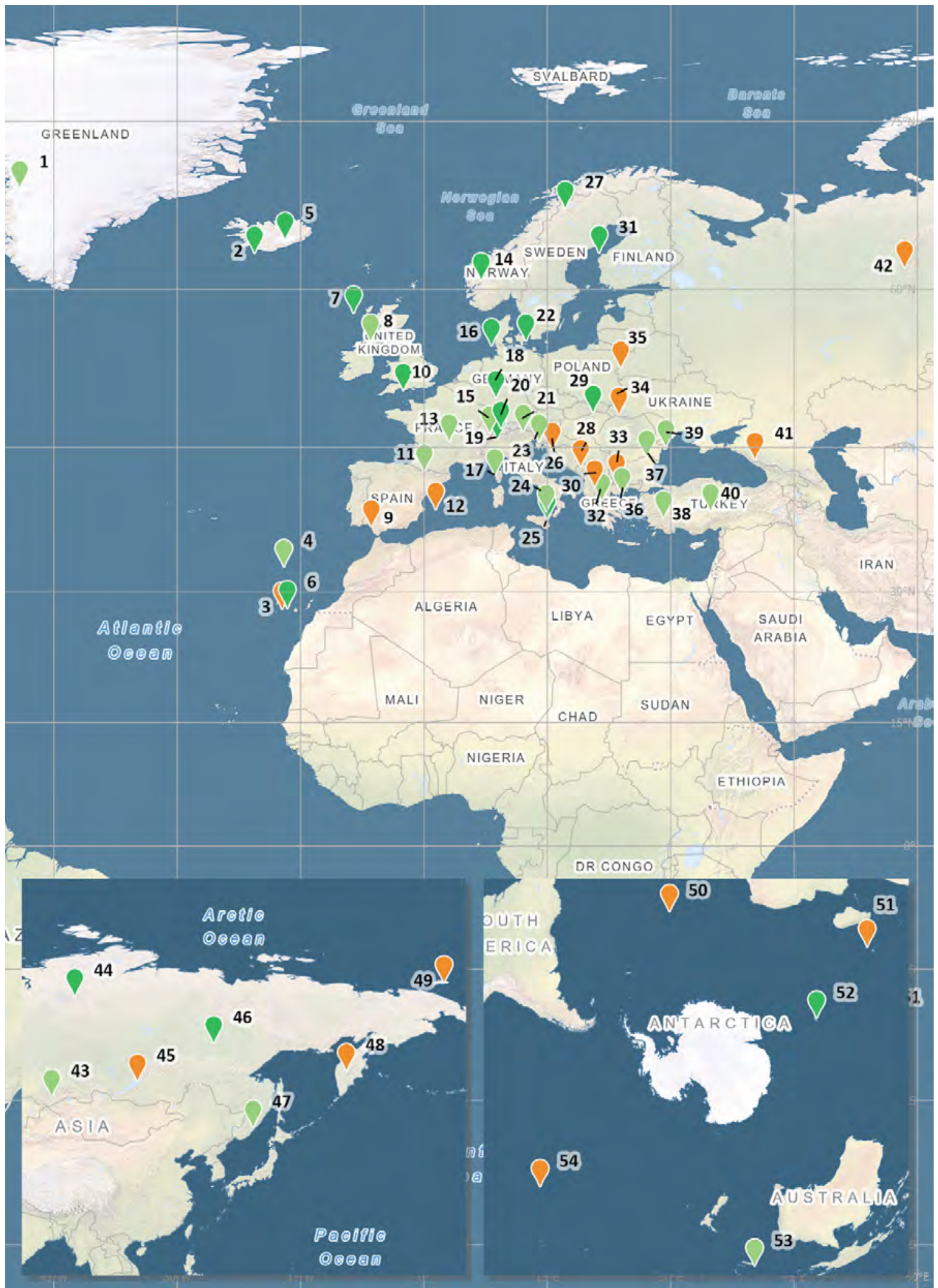


Results of the IUCN World Heritage Outlook 3 show that, of all natural World Heritage sites in North America (total of 22 sites), the conservation outlook is "good" for 27\%, and "good with some concerns" for a further 63\%. The conservation outlook of one site (4.5\%) is "significant concern", and "critical" for one further site (4.5\%).

Conservation outlook 2020 for natural World Heritage in North America

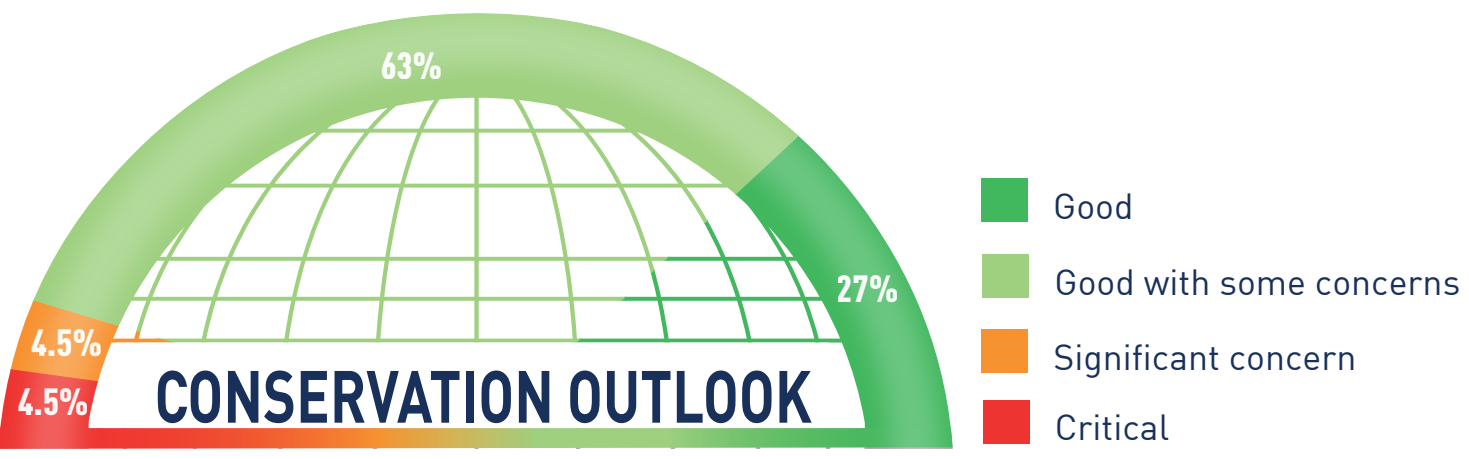

One new site was inscribed in North America since 2018:

\begin{tabular}{llll} 
Site & Country & Conservation Outlook 2020 & Inscription year \\
\hline Pimachiowin Aki & Canada & Good & 2018 \\
\hline
\end{tabular}

Of the sites that were inscribed in 2017 or earlier, and therefore already assessed in the IUCN World Heritage Outlook 2017, Papahānaumokuākea deteriorated from a "good" conservation outlook to "good with some concerns".

Site Country Conservation Outlook 2017 Conservation Outlook 2020

Papahānaumokuākea USA Good Good with some concerns 
IUCN WORLD HERITAGE OUTLOOK 3

\section{Threats}

Climate change and invasive alien species are the most prevalent current threats assessed as high or very high across natural World Heritage sites in North America.

Current threats assessed as high or very high in 2020. Figures are based on the number of sites where these threats occur

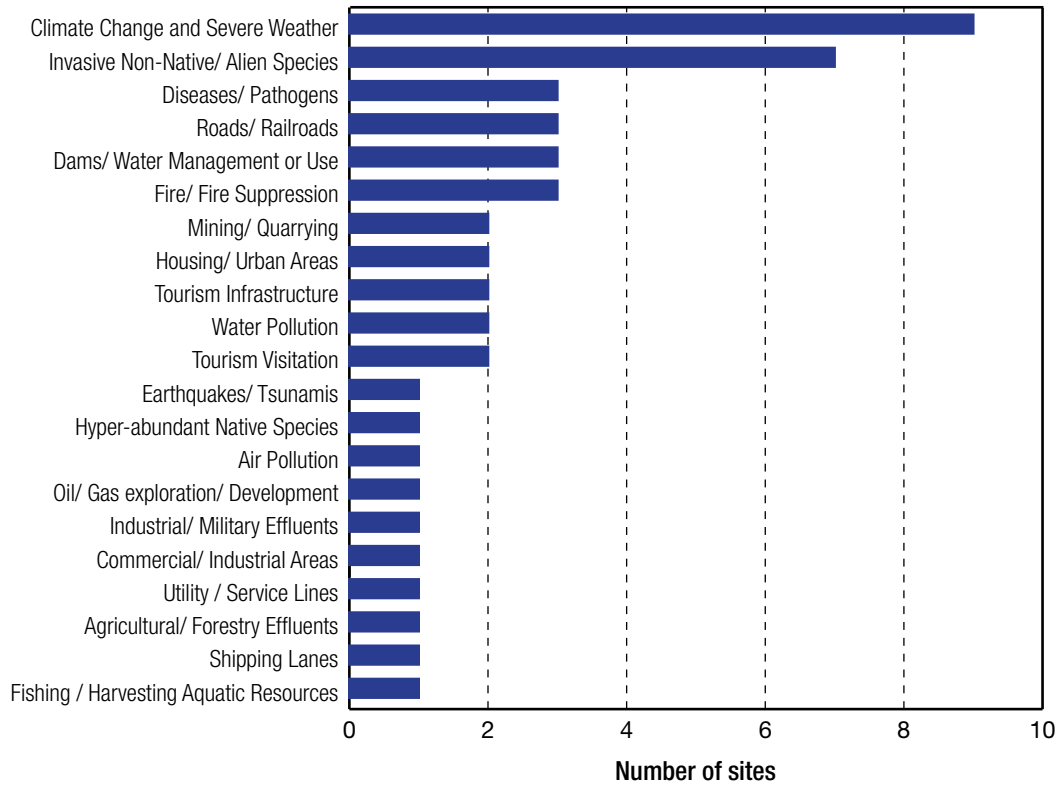

\section{Protection and management}

Over three-quarters of North American natural World Heritage sites are considered to be under effective protection and management, with 23\% assessed as highly effective and 54\% as mostly effective. A further 23\% of sites in the region are of some concern regarding protection and management, however, no sites in North America are assessed as serious concern.

2020 results for protection and management, \% of all sites in the region

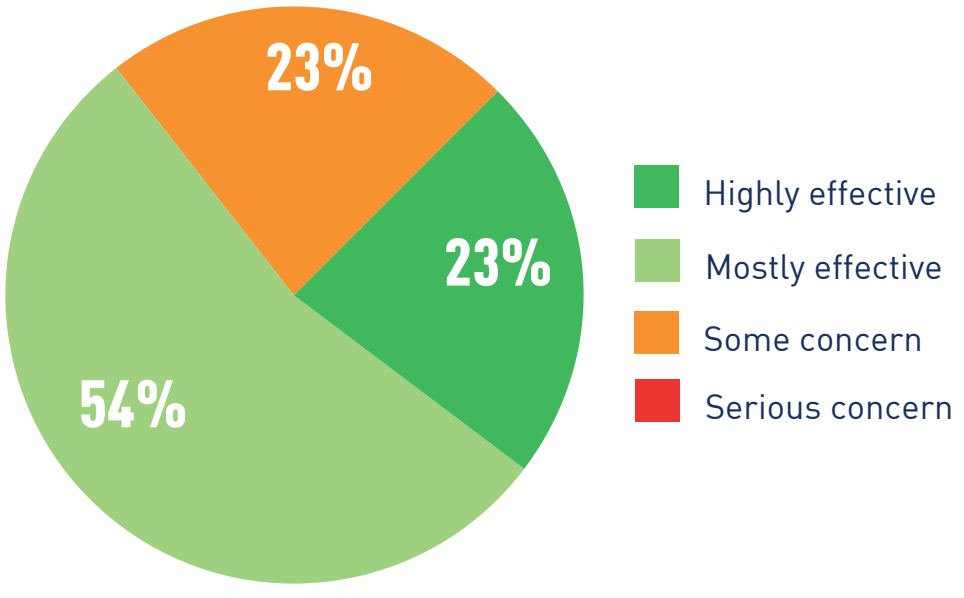




\begin{tabular}{|c|c|}
\hline Map marker & Site \\
\hline 12 & Dinosaur Provincial Park, Canada \\
\hline 2 & Hawaii Volcanoes National Park, USA \\
\hline 20 & Joggins Fossil Cliffs, Canada \\
\hline 19 & Miguasha National Park, Canada \\
\hline 22 & Mistaken Point, Canada \\
\hline 15 & Pimachiowin Aki, Canada \\
\hline
\end{tabular}

GOOD

$\begin{array}{ll}8 & \text { Canadian Rocky Mountain Parks, Canada } \\ 14 & \text { Carlsbad Caverns National Park, USA } \\ 11 & \text { Grand Canyon National Park, USA } \\ 17 & \text { Great Smoky Mountains National Park, USA } \\ 21 & \text { Gros Morne National Park, Canada } \\ 3 & \text { Kluane / Wrangell-St Elias / Glacier Bay / Tatshenshini-Alsek, Canada, USA } \\ 16 & \text { Mammoth Cave National Park, USA } \\ 4 & \text { Nahanni National Park, Canada } \\ 6 & \text { Olympic National Park, USA } \\ 1 & \text { Papahänaumokuäkea, USA } \\ 5 & \text { Redwood National and State Parks, USA } \\ 9 & \text { Waterton-Glacier International Peace Park, Canada, USA } \\ 13 & \text { Yellowstone National Park, USA } \\ 1 & \text { Yosemite National Park, USA } \\ 18 & \text { Wood Buffalo National Park, Canada } \\ & \end{array}$

$\Delta$ The conservation outlook improved since $2017 \quad \nabla$ The conservation outlook deteriorated since 2017 * New site inscribed on the World Heritage List since 2018 


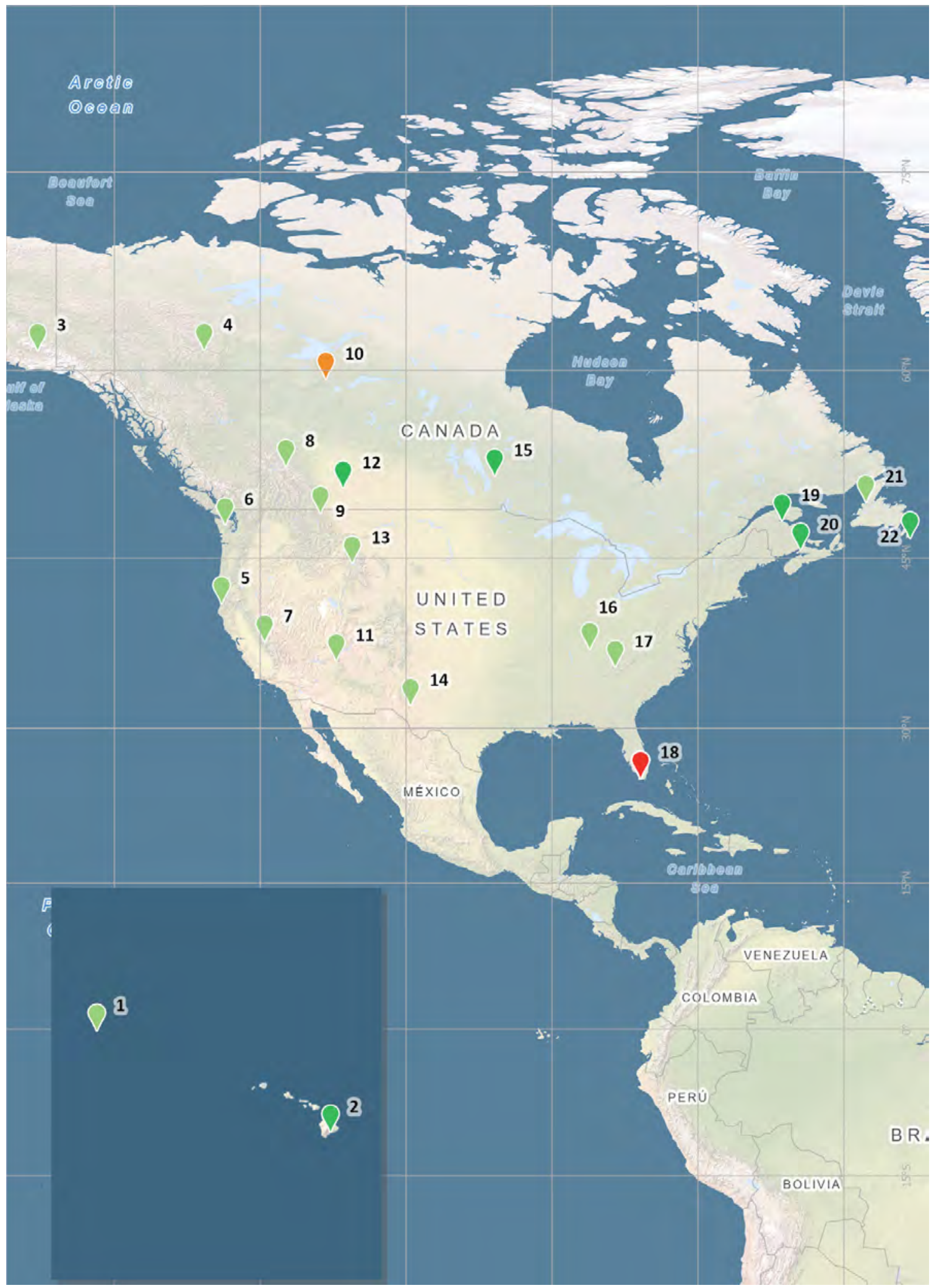


Results of the IUCN World Heritage Outlook 3 show that, of all natural World Heritage sites in Mesoamerica and the Caribbean (total of 21 sites), the conservation outlook is "good with some concerns" for 48\%, with no sites assessed as having a "good" conservation outlook. For 43\% of the sites, the conservation outlook is of "significant concern", and for two sites (9\%) the conservation outlook is assessed as "critical".

Conservation Outlook 2020 for natural World Heritage in Mesoamerica and the Caribbean
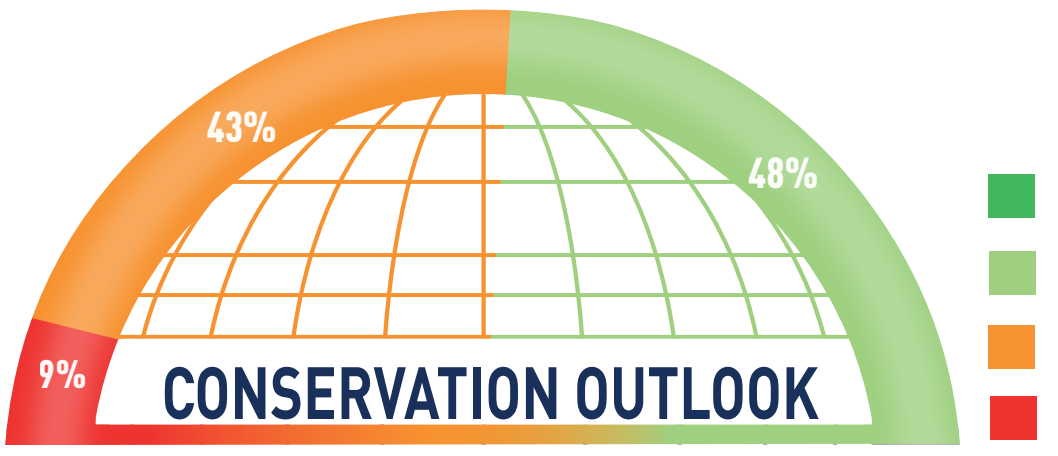

Good

Good with some concerns

Significant concern

Critical

One new site was inscribed in Mesoamerica and the Caribbean since 2018:

\begin{tabular}{llll} 
Site & Country & Conservation Outlook 2020 & Inscription year \\
\hline $\begin{array}{l}\text { Tehuacán-Cuicatlán Valley: } \\
\text { originary habitat of Mesoamerica }\end{array}$ & Mexico & Good with some concerns & 2018 \\
\hline
\end{tabular}

Of the sites that were inscribed in 2017 or earlier, and therefore already assessed in the IUCN World Heritage Outlook 2017, two sites changed in conservation outlook and both are in Mexico. In the Monarch Butterfly Reserve, the conservation outlook improved from "critical" to "significant concern". In the Islands and Protected Areas of the Gulf of California which was included on the List of World Heritage in Danger in 2019 due to the imminent extinction of the endemic vaquita, the conservation outlook deteriorated from "significant concern" to "critical".

\begin{tabular}{llll} 
Site & Country & Conservation Outlook 2017 & Conservation Outlook 2020 \\
\hline $\begin{array}{l}\text { Islands and Protected Areas of } \\
\text { the Gulf of California }\end{array}$ & Mexico & Significant concern & Critical \\
\hline $\begin{array}{l}\text { Monarch Butterfly Biosphere } \\
\text { Reserve }\end{array}$ & Mexico & Critical & Significant concern \\
\hline
\end{tabular}


IUCN WORLD HERITAGE OUTLOOK 3

\section{Threats}

The most prevalent current threats to natural World Heritage sites in Mesoamerica and the Caribbean are climate change and fishing, followed by invasive alien species.

Current threats assessed as high or very high in 2020. Figures are based on the number of sites where these threats occur

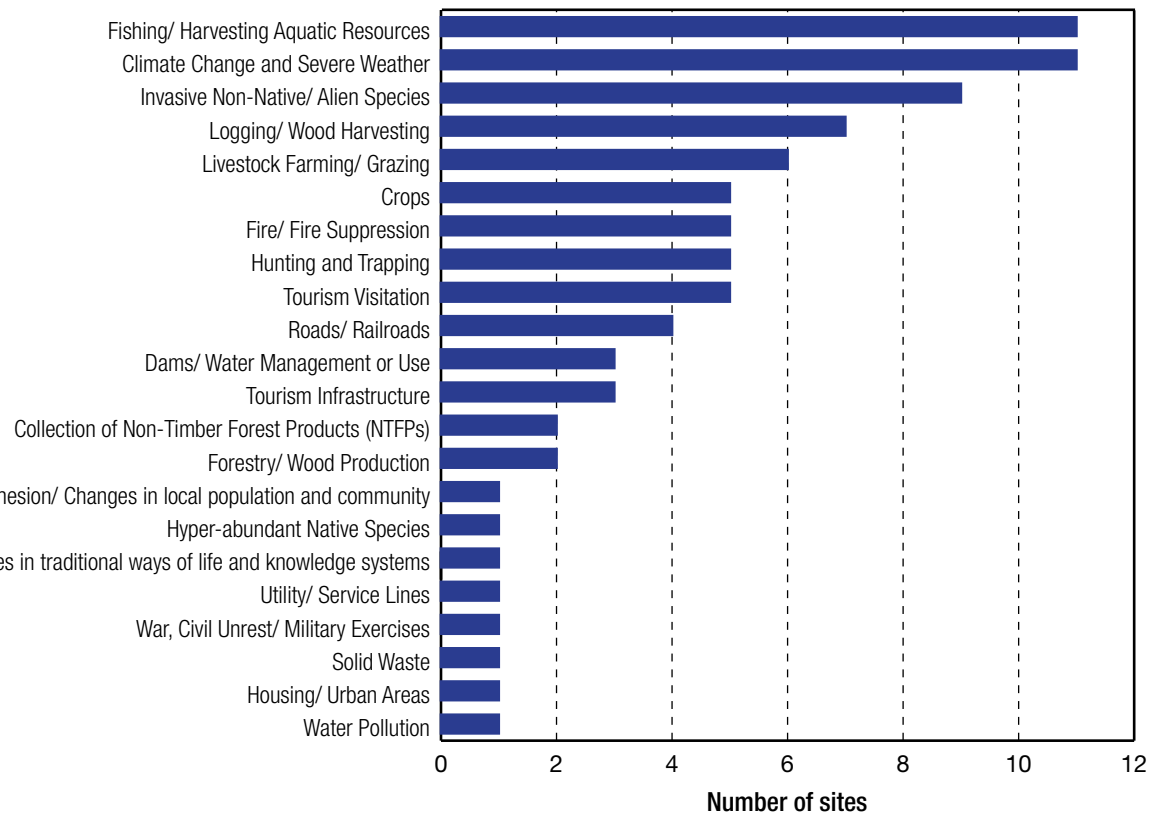

\section{Protection and management}

Slightly more than a quarter of sites (28\%) are found to be mostly effective in their protection and management in Mesoamerica and the Caribbean, with none highly effective. In 67\% of all sites, protection and management are assessed as of some concern and in one site (5\%) as of serious concern.

2020 results for protection and management, \% of all sites in the region

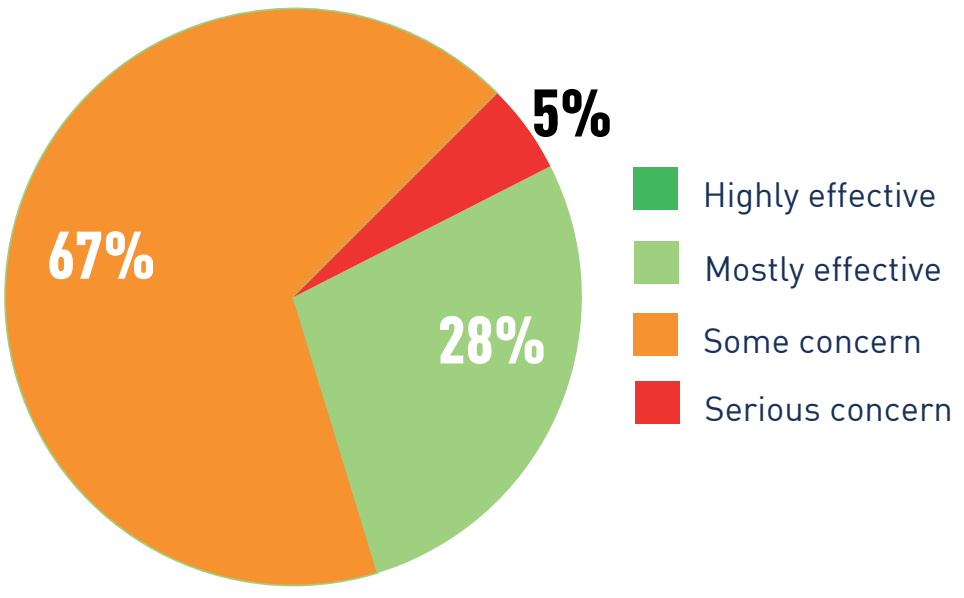




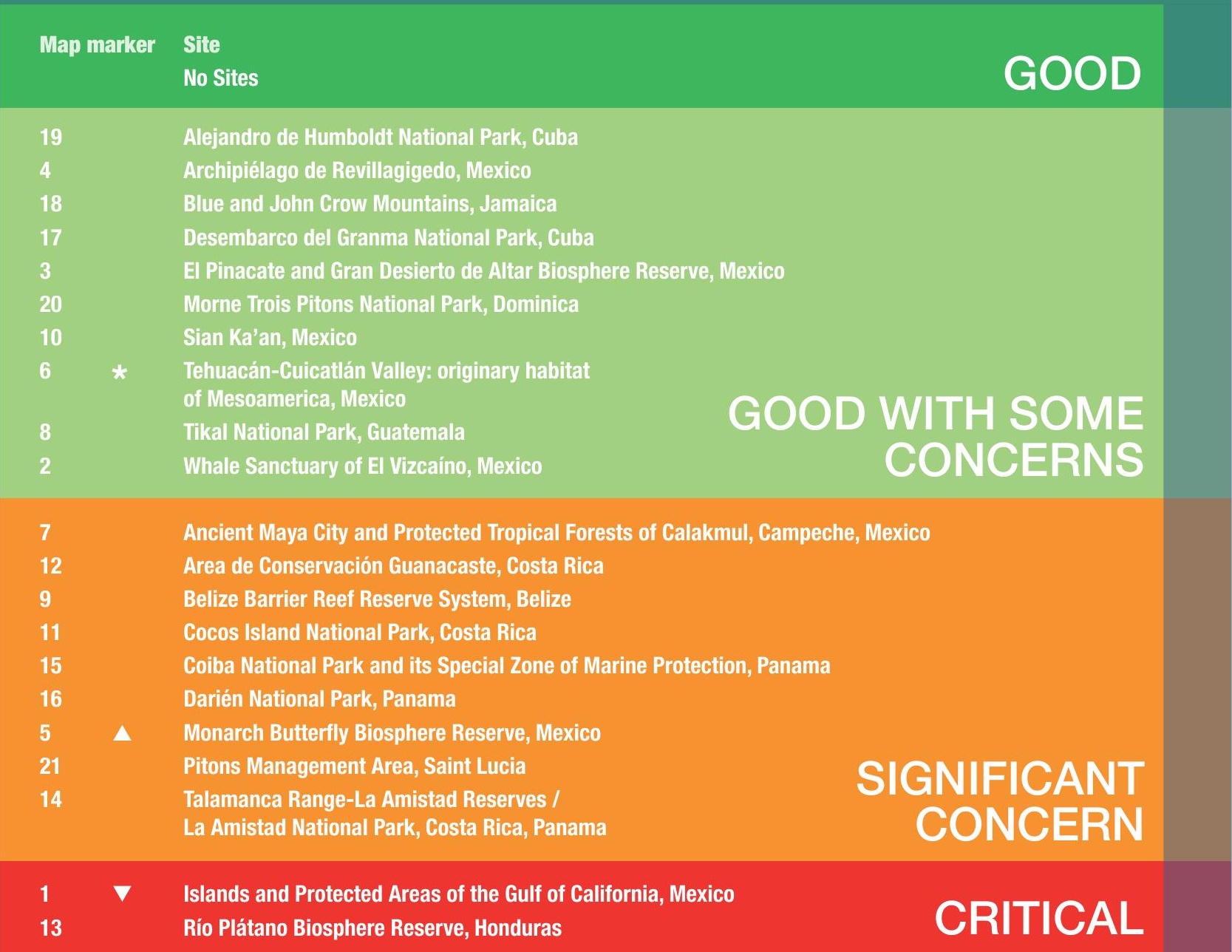

$\Delta$ The conservation outlook improved since $2017 \quad \nabla$ The conservation outlook deteriorated since 2017 * New site inscribed on the World Heritage List since 2018 
IUCN WORLD HERITAGE OUTLOOK 3

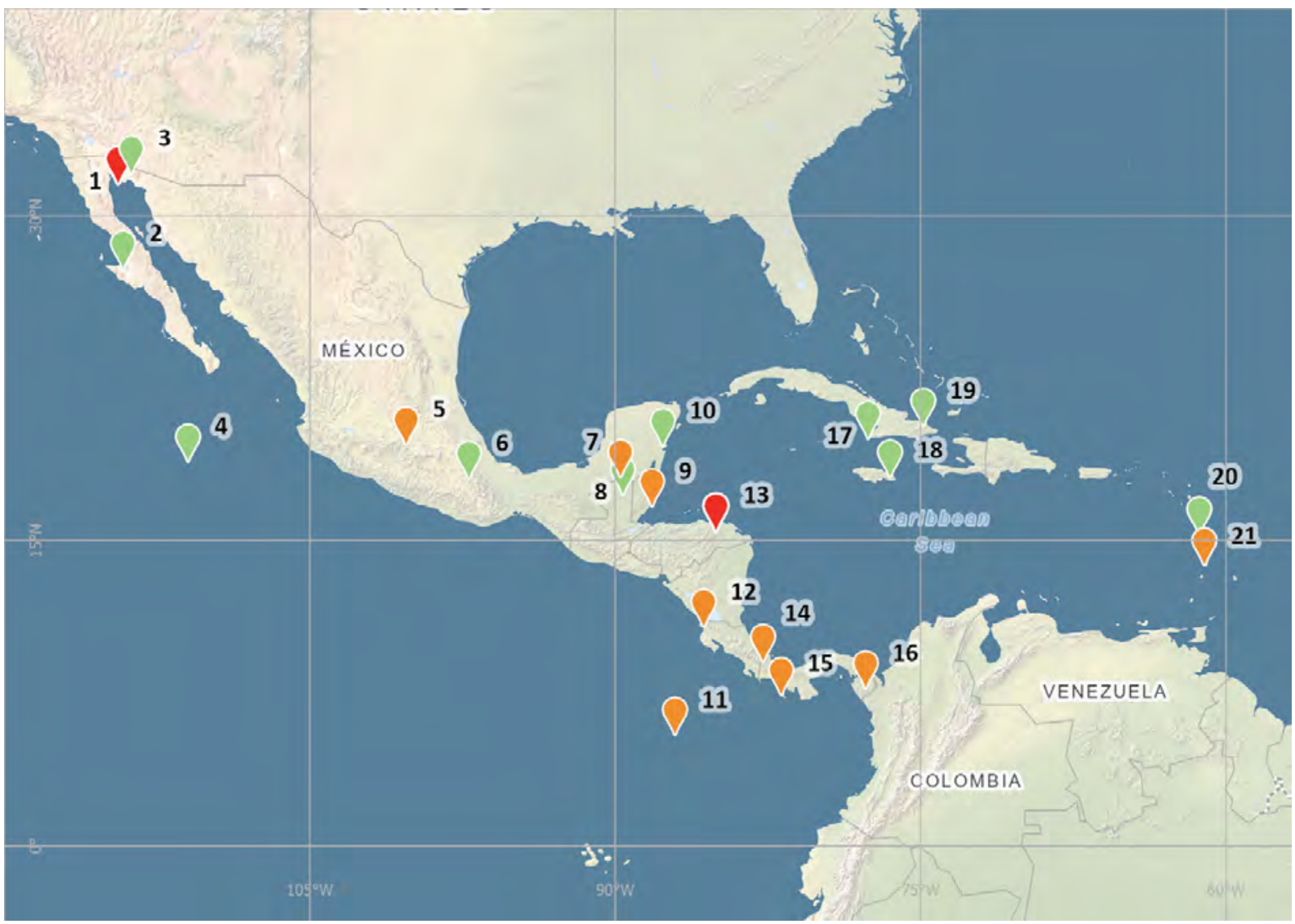




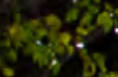

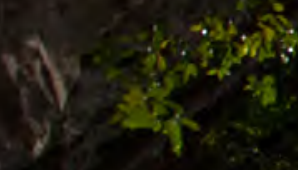

sint 15

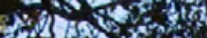
5. op 13 was (3)

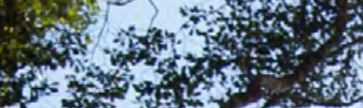

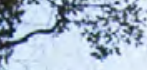

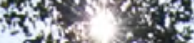

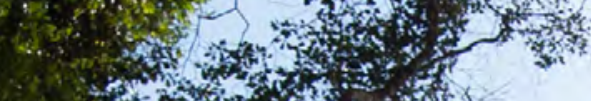

36 int 20 in
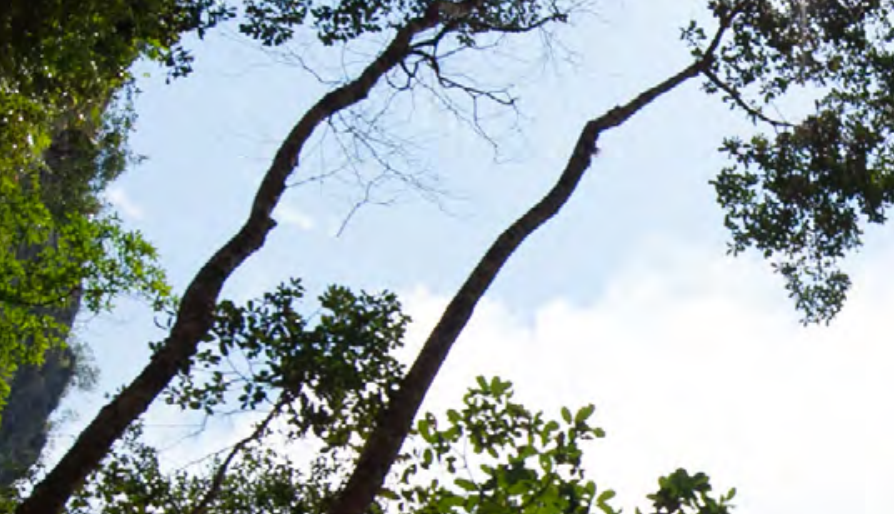

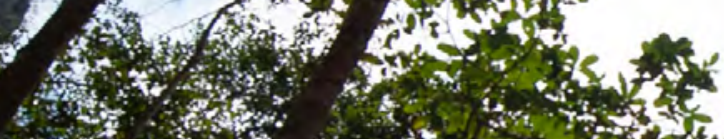
s.14.

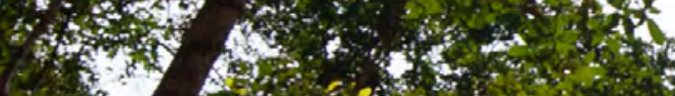

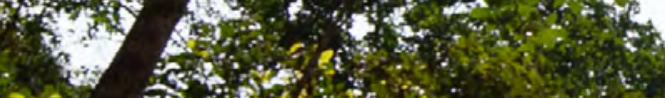

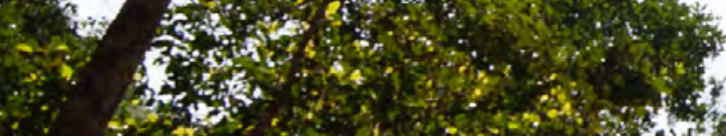
South Americá 


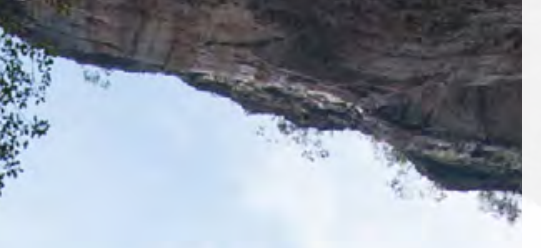

\section{Facts and figures: South America}

* 21 natural and 4 mixed World Heritage sites in $\mathbf{8}$ countries

* $35,542,823$ hectares in total

* 4 marine and coastal sites

* 0 transnational sites

* O sites listed as "in danger"

* 2 new sites since 2018

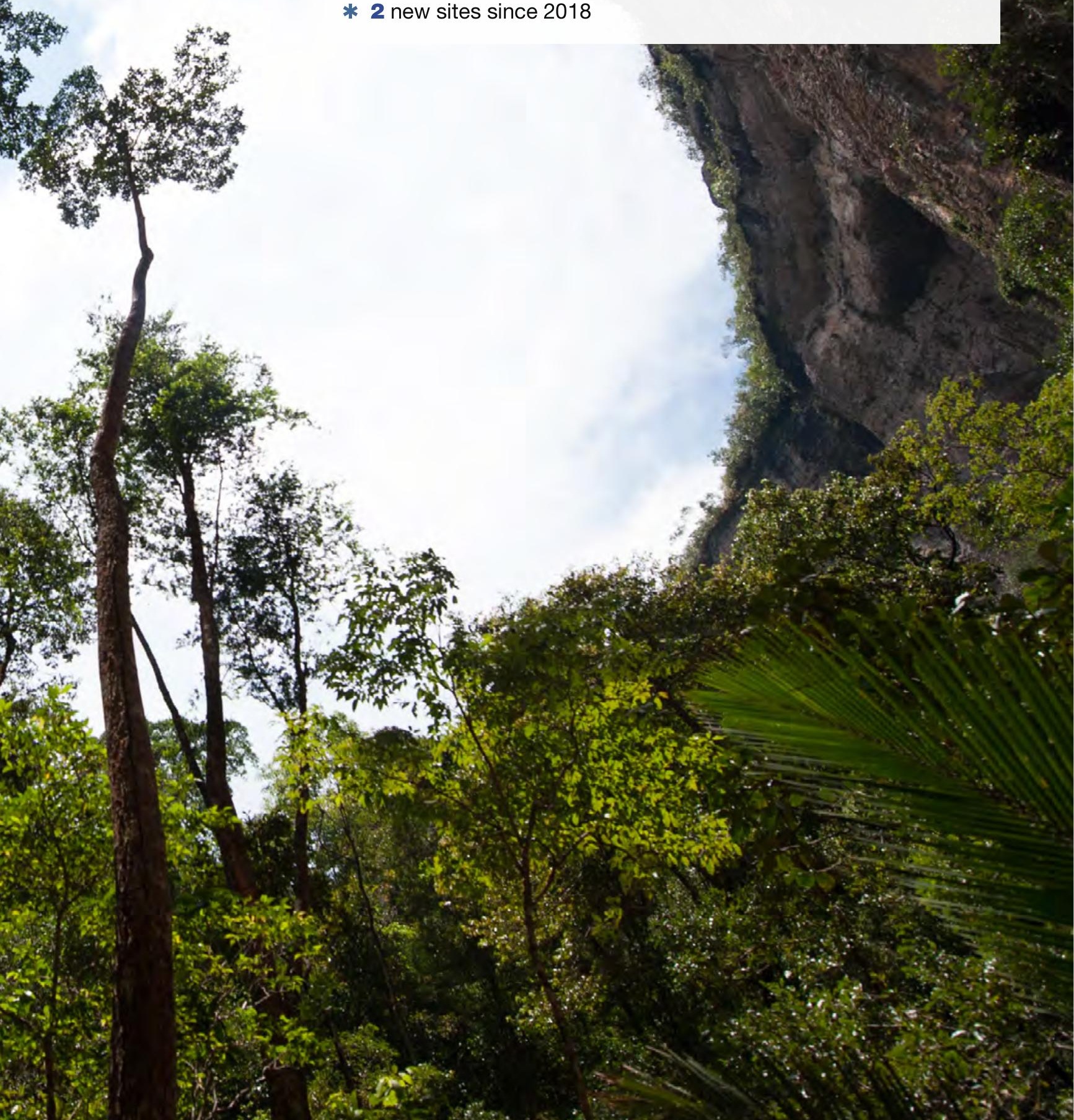


Results of the IUCN World Heritage Outlook 3 show that, of all natural and mixed World Heritage sites in South America (total of 25 sites), for two sites (8\%) the conservation outlook is "good", for 44\% the conservation outlook is "good with some concerns", and for $48 \%$ it is assessed as "significant concern". There are no sites in the region with a conservation outlook assessed as "critical".

Conservation Outlook 2020 for natural World Heritage in South America

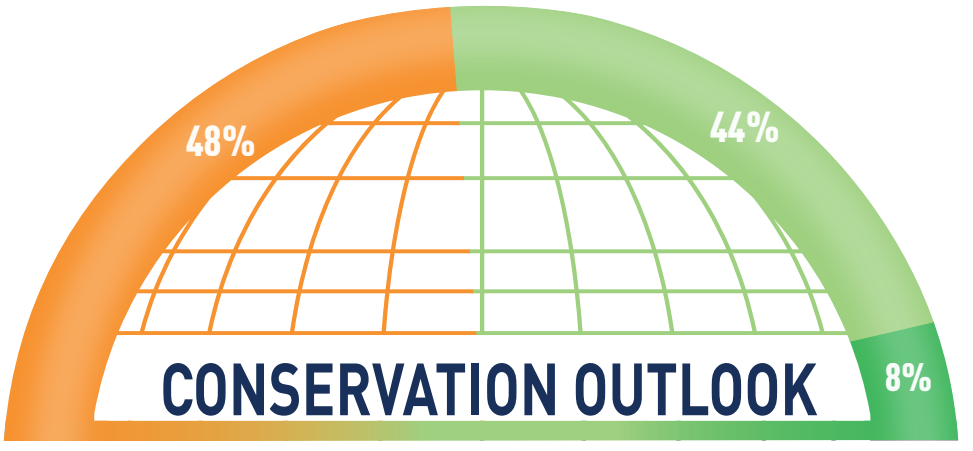

Good

Good with some concerns

Significant concern

Critical

Two new sites were inscribed in South America since 2018:

\begin{tabular}{llll} 
Site & Country & Conservation Outlook 2020 & Inscription year \\
\hline $\begin{array}{l}\text { Chiribiquete National Park - "The } \\
\text { Maloca of the Jaguar" }\end{array}$ & Colombia & Good with some concerns & 2018 \\
\hline $\begin{array}{l}\text { Paraty and llha Grande - Culture and } \\
\text { Biodiversity }\end{array}$ & Brazil & Good with some concerns & 2019 \\
\hline
\end{tabular}

Of the sites that were inscribed in 2017 or earlier, and therefore already assessed in the IUCN World Heritage Outlook 2017, two sites changed conservation outlook; one improved from "significant concern" to "good with some concerns", while one deteriorated from "good with some concerns" to "significant concern". The positive developments include Península Valdés (Argentina), where the population of southern right whale, for which the site is a globally significant breeding ground, has been increasing following unusually high levels of whale mortality recorded previously.

\begin{tabular}{llll} 
Site & Country & Conservation Outlook 2017 & Conservation Outlook 2020 \\
\hline $\begin{array}{l}\text { Brazilian Atlantic Islands: Fernando } \\
\text { de Noronha and Atol das Rocas } \\
\text { Reserves }\end{array}$ & Brazil & Good with some concerns & Significant concern \\
\hline Península Valdés & Argentina & Significant concern & Good with some concerns \\
\hline
\end{tabular}


IUCN WORLD HERITAGE OUTLOOK 3

\section{Threats}

Livestock grazing and climate change are the most prevalent threats to South American natural World Heritage sites, followed by fishing.

Current threats assessed as high or very high in 2020. Figures are based on the number of sites where these threats occur

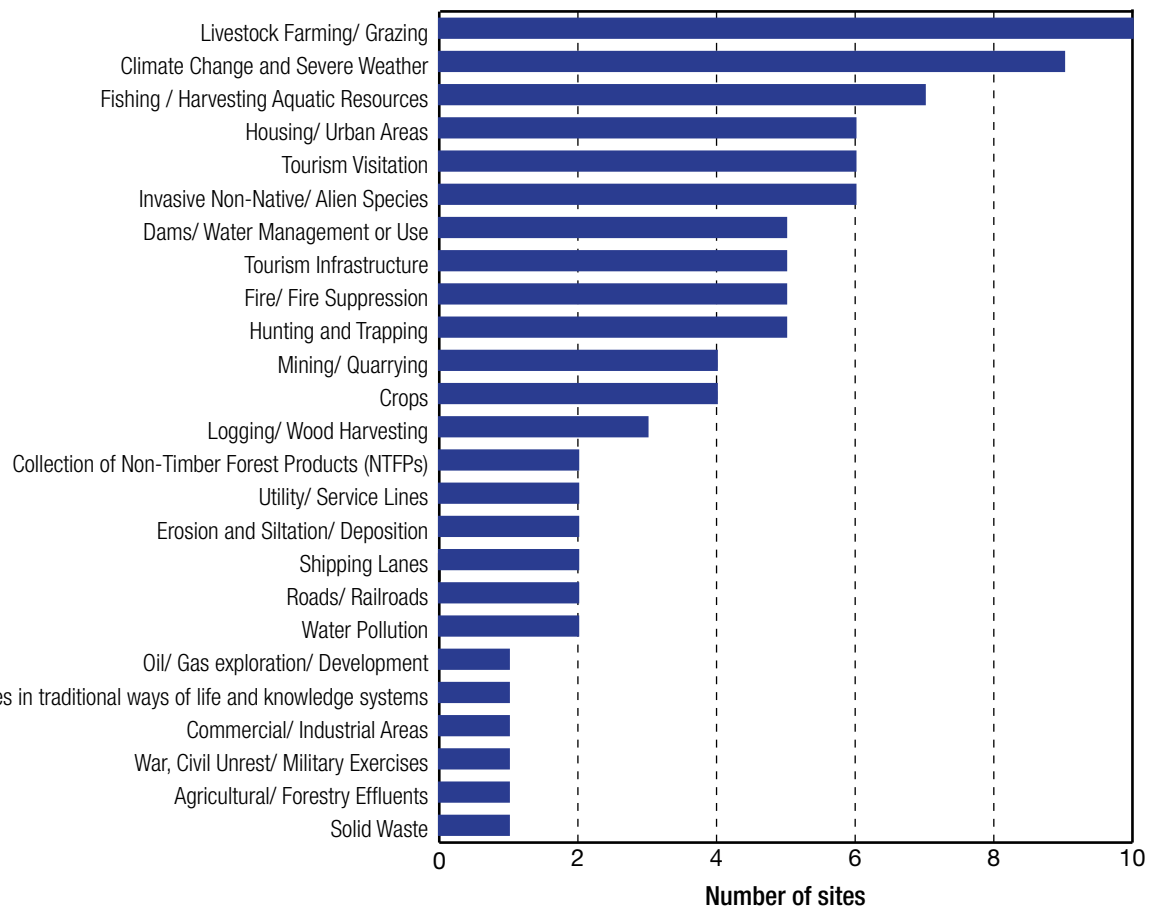

\section{Protection and management}

$32 \%$ of natural World Heritage sites in South America have mostly effective protection and management in place. No sites are found to be highly effective. For $60 \%$ of sites, protection and management are assessed as of some concern and of serious concern for two sites (8\%).

2020 results for protection and management, \% of all sites in the region

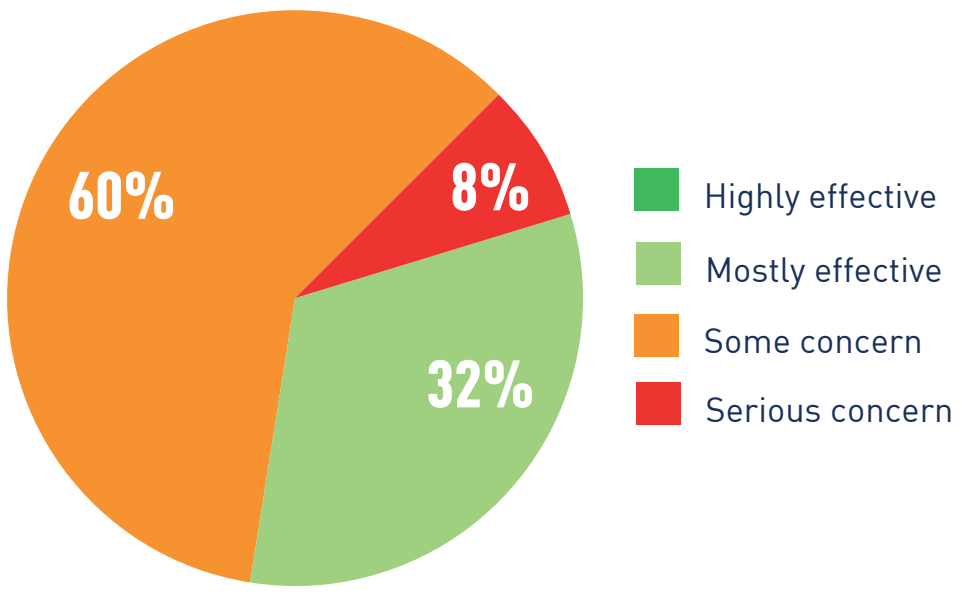




\section{Map marker Site}

12

Ischigualasto-Talampaya Natural Parks, Argentina

$10 \quad$ Los Alerces National Park, Argentina

\begin{tabular}{|c|c|c|}
\hline 14 & & Central Amazon Conservation Complex, Brazil \\
\hline 18 & & Central Suriname Nature Reserve, Suriname \\
\hline 22 & & Cerrado Protected Areas: Chapada dos Veadeiros and Emas National Parks, Brazil \\
\hline 8 & * & Chiribiquete National Park - "The Maloca of the Jaguar", Colombia \\
\hline 7 & & Los Glaciares National Park, Argentina \\
\hline 2 & & Malpelo Fauna and Flora Sanctuary, Colombia \\
\hline 16 & & Noel Kempff Mercado National Park, Bolivia \\
\hline 23 & * & Paraty and Ilha Grande - Culture and Biodiversity, Brazil \\
\hline 13 & $\Delta$ & Peninsula Valdés, Argentina \\
\hline & & Rio Abiseo National Park, Peru \\
\hline & & Sangay National Park, Ecuador \\
\hline
\end{tabular}

\section{$21 \quad$ Atlantic Forest Southeast Reserves, Brazil}

$25 \quad \nabla \quad$ Brazilian Atlantic Islands: Fernando de Noronha and Atol das Rocas Reserves, Brazil

$15 \quad$ Canaima National Park, Venezuela

24 Discovery Coast Atlantic Forest Reserves, Brazil

$1 \quad$ Galápagos Islands, Ecuador

$9 \quad$ Historic Sanctuary of Machu Picchu, Peru

$4 \quad$ Huascarán National Park, Peru

$20 \quad$ Iguaçu National Park, Brazil

19 Iguazú National Park, Argentina

$6 \quad$ Los Katios National Park, Colombia

$11 \quad$ Manú National Park, Peru

17 Pantanal Conservation Area, Brazil

\section{SIGNIFICANT CONCERN}

No sites

\section{CRITICAL}

$\Delta$ The conservation outlook improved since $2017 \quad \nabla$ The conservation outlook deteriorated since 2017 * New site inscribed on the World Heritage List since 2018 
IUCN WORLD HERITAGE OUTLOOK 3

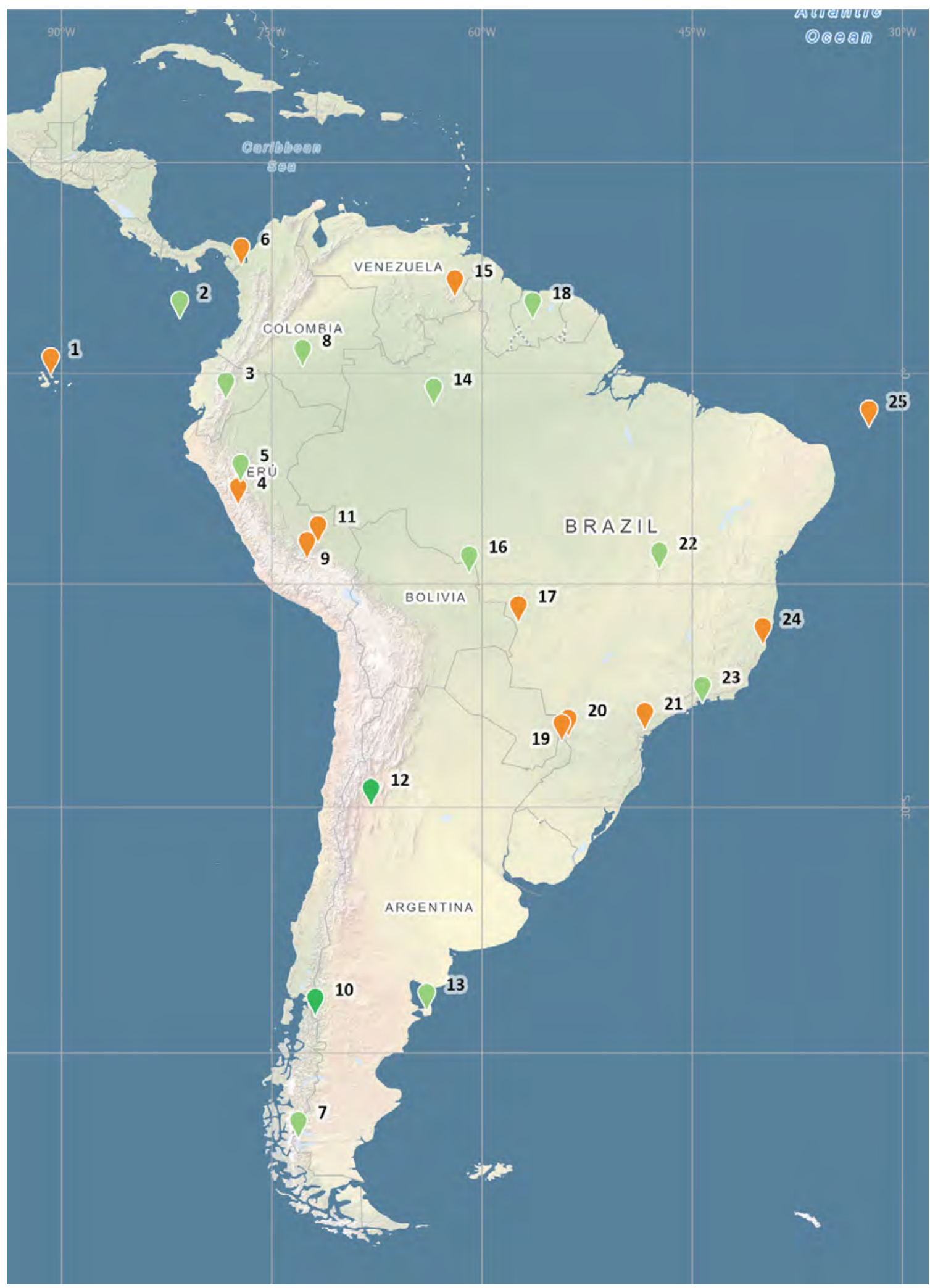




\section{Regional comparison}

The IUCN World Heritage Outlook also enables trends in conservation outlook of natural World Heritage sites to be explored across regions, including through the identification of key similarities and differences among and between regions.

When comparing the results, the regional differences are consistent with the results from 2017. North America remains the region with the highest percentage of sites "in the green" (assessed as "good" or "good with some concerns") - 90\%, followed by Oceania (73\%), Asia (72\%) and Europe (69\%). These are followed by South America (52\%), Arab States (50\%), Mesoamerica and the Caribbean (48\%) and Africa (42\%), with Africa now becoming the region with the smallest percentage of sites whose outlook is assessed as good or good with some concerns. Europe, South America, and Mesoamerica and the Caribbean are three regions that have had an overall increase in the number of sites with a positive outlook, while Asia, Oceania, the Arab States and Africa are showing a decreasing trend.

Figure 14. Percentage of sites assessed overall as "good" or "good with some concern" in 2017 and 2020 across all regions

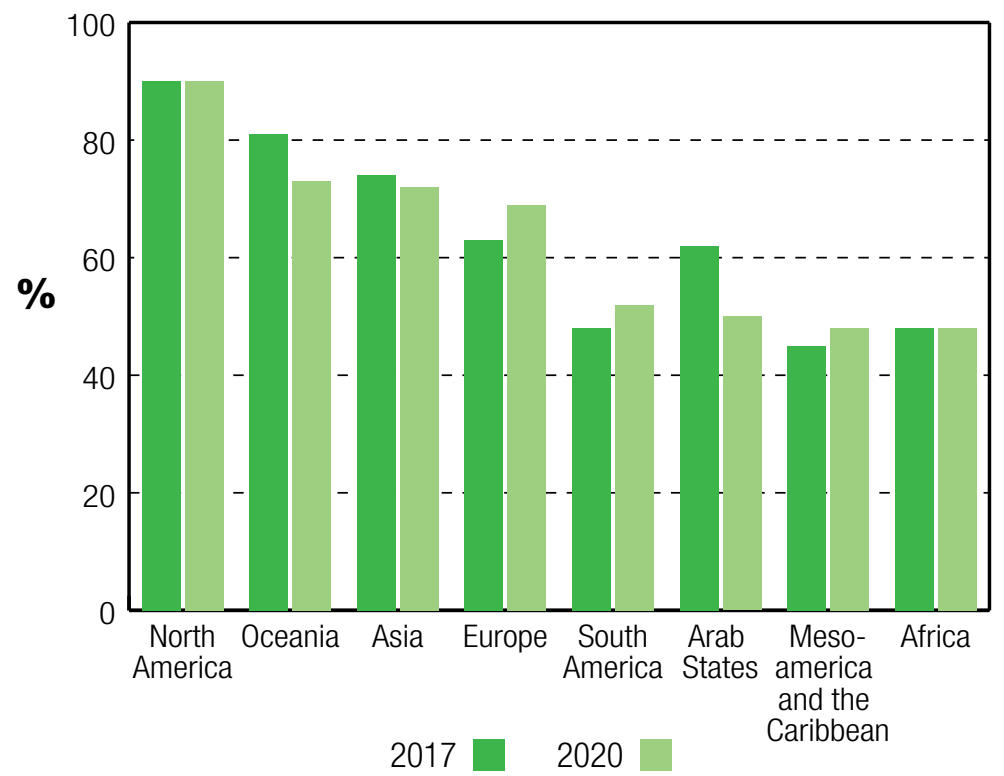

Significant differences are also observed at the level of the three main elements of the IUCN World Heritage Outlook - values, threats and protection and management. Oceania remains the region with the highest percentage of effectively managed sites (95\% of sites assessed as having "highly effective" or "mostly effective" management overall), followed by North America (77\%). Europe (54\%) and Asia (52\%) are just above the overall global result (50\% in the green) and other regions are below the global average - South America (32\%), Africa (30\%), Mesoamerica and the Caribbean (28\%) and the Arab States (12.5\%). An increase in sites with overall effective management has been observed in Europe, Asia, South America, Mesoamerica and the Caribbean and the Arab States compared to 2017. One should note that in the Arab States this is based on the improvement in one site (Wadi Al-Hitan - see text box on page 10 for more details), however, due to the small number of sites in the region (eight in total), the percentage increase looks rather higher compared to other regions. 
Figure 15. Percentage of sites assessed overall as having "highly effective" or "mostly effective" protection and management in 2017 and 2020 across all regions

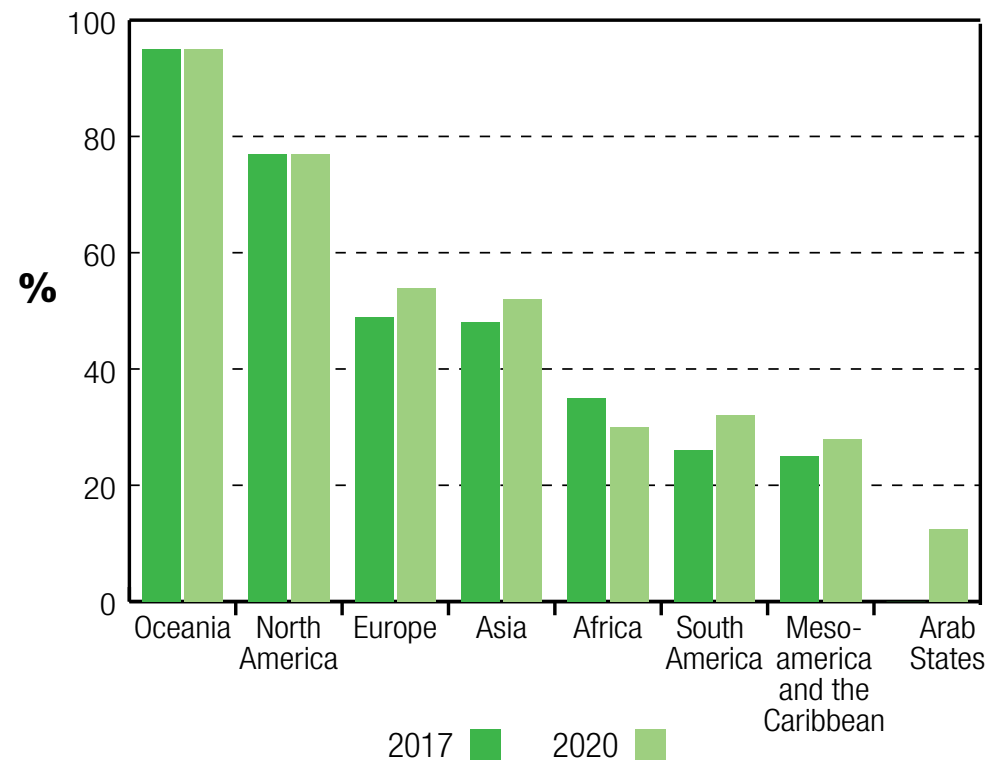

While in 2017 all regions identified invasive alien species, climate change and impacts of tourism as the top three current threats, in 2020 some regional differences have been observed. Direct resource use (hunting and/ or fishing) has become one of the most prominent high or very high threats in Africa, Asia and Mesoamerica and the Caribbean. Solid waste has moved to the top three current high threats in the Arab States (which is particularly linked to plastic pollution of marine areas) and livestock grazing moved to the top three threats in South America. 
Figure 16. The top current threats assessed as high or very high in 2020 in different regions

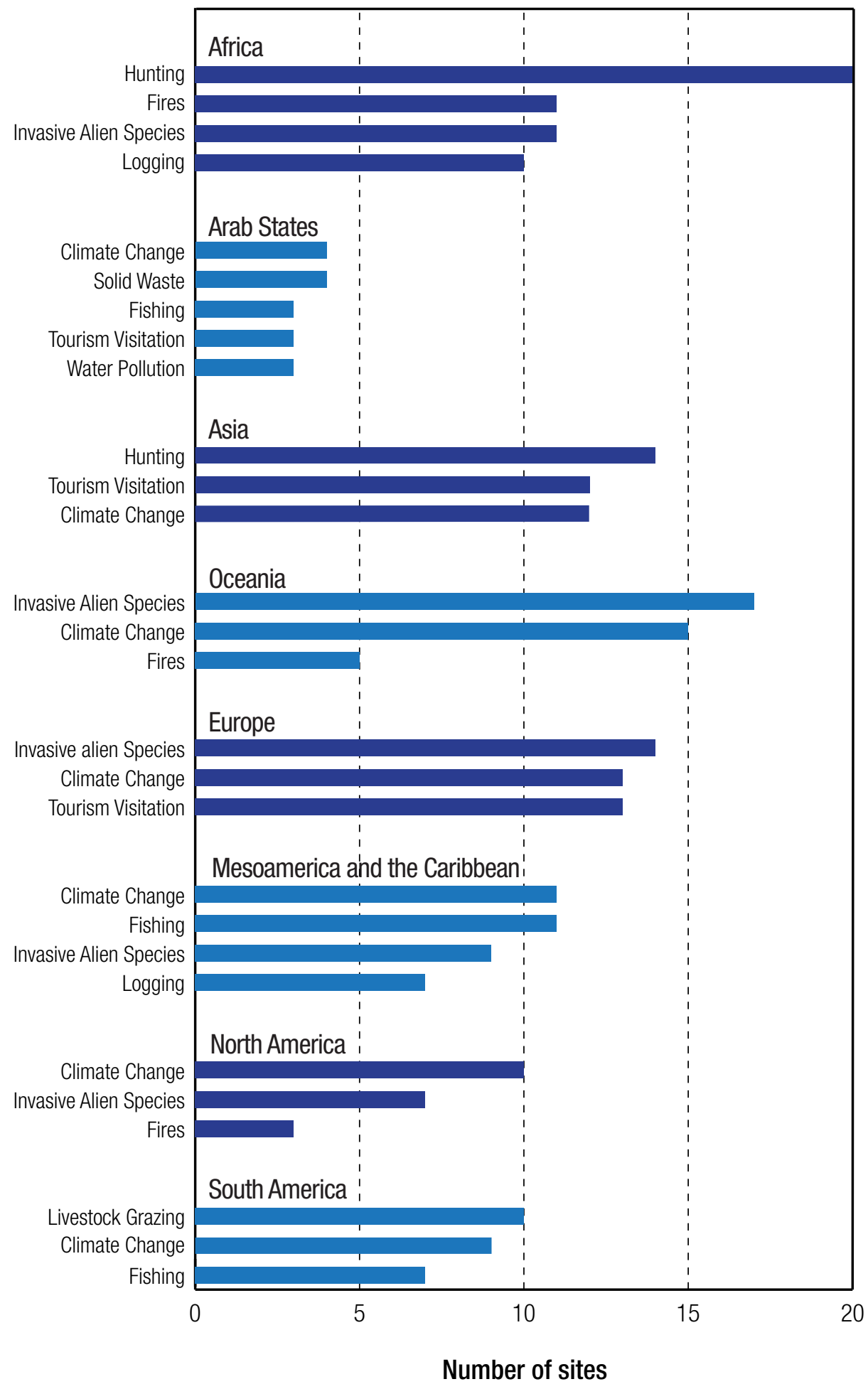




\section{Key findings and conclusions}

The IUCN World Heritage Outlook 3 builds on three cycles of Conservation Outlook Assessments undertaken since 2014. It presents the main results for 2020, but also some longer-term trends based on a comparison of three data sets now available.

- In terms of global results, the picture remains similar to 2017 and 2014, with the conservation outlook being "good" or "good with some concerns" for 63\% of sites, of "significant concern" for 30\% and "critical" for 7\%.

- Many changes in conservation outlook are observed at the level of individual sites and regions, and in relation to threats and protection and management. The conservation outlook of 24 sites changed between 2017 and 2020: 8 improved and 16 deteriorated, which represents a significant difference from 2017, where the conservation outlook improved for more sites (14), and deteriorated for fewer sites (12) compared with 2014.

- Considering all three sets of data spanning back to 2014, a total of 43 sites changed their conservation outlook at least once. Of these, in 18 cases conservation outlook improved and in 25 cases it deteriorated. For a few sites the trends have been mixed, as their conservation outlook changed both between 2014 and 2017 and between 2017 and 2020.

- Climate change has become the most prominent current threat. Overall, it is assessed as a high or a very high threat in 83 out of 252 sites. Climate change still remains by far the largest potential threat and is also the highest threat affecting values under all four natural criteria. This result reinforces the need for a coordinated strategy on increasing awareness, policy and action on mitigation and adaptation at the global and site levels.

- Invasive alien species follows closely behind as the second most common current threat. It is followed by impacts from visitation, hunting, fishing, water pollution, fires and logging. In some cases, such as invasive alien species and fire, the cause and effect relationship with climate change needs to be understood and planned for in order to combat these growing impacts on natural World Heritage sites.

- While the top three current threats have remained the same as in 2017, significant regional differences were observed in 2020, with direct resource use (hunting and/or fishing) becoming one of the most prevalent high or very high threats in Africa, Asia and Mesoamerica and the Caribbean. Solid waste has become one of the top three current threats in the Arab States (which is particularly linked to plastic pollution of marine areas) and livestock grazing is now one of the top three threats in South America.

- Overall, the state of natural World Heritage values in 68\% of sites is considered to be good or of low concern. While overall the picture is very similar to that in 2017, the situation has slightly worsened for species and habitats values recognised under criterion $(x)$, with only $58 \%$ of these values assessed to be in a good state or of low concern in 2020, compared to 62\% in 2017.

- When considering values associated with different criteria, similar to the results from previous assessment cycles, the biodiversity values (criteria (ix) for ecological processes, and (x) for species) continue to be of higher concern, with many more values assessed as of high concern or critical.

- Following some reduction between 2014 and 2017, the percentage of sites with overall highly or mostly effective protection and management has slightly increased in 2020 (50\% compared to 48\% in 2017 for the 228 sites, for which three data sets are now available). An increase in the percentage of sites with overall effective management has been observed in Europe, Asia, South America, Mesoamerica and the Caribbean and the Arab States compared to 2017. 
- Analysis of specific aspects of protection and management shows that some areas assessed as being of highest concern in 2017 have remained so in 2020. For example, sustainable finance has been assessed as of some or serious concern in more than half of all sites, similar to 2017. However, new management challenges have emerged in 2020, for example the onset of the COVID-19 pandemic.

- The timing of the IUCN World Heritage Outlook 3 could not allow for a systematic assessment of COVID-19 impacts. However, over 50 site assessments mention factors related to the COVID-19 pandemic and some further assessments note that its consequences remain to be seen. In some sites, a short-term decrease in tourism visitation may have reduced pressure on natural ecosystems. However, more sites may be facing negative impacts related to disruptions in conservation work, loss of control over illegal activities, decreases in funding, particularly from tourism related income, and concerns about potential transmission of the virus to wild animal populations.

At a time of great uncertainty, securing the future of natural World Heritage sites, the world's most significant protected areas, is needed more than ever. However, as observed from IUCN World Heritage Outlook data since 2014, a significant proportion of these sites have been under sustained pressure from local and global threats, and protection and management issues.

Natural World Heritage sites, particularly those inscribed under biodiversity criteria (ix) and (x), are highly important for the protection of globally endangered and endemic species. Many natural sites offer examples of effective management for species conservation and offer solutions that can be replicated elsewhere. The IUCN World Heritage Outlook reinforces the importance of such sites as the world enters the Post-2020 Global Biodiversity Framework. However, the impact of threats and ineffective protection and management on these biodiversity sites is resulting in a poorer conservation outlook relative to other non-biodiversity criteria.

This emphasises the critical need to focus attention on improving these sites' capacity to realise the contribution natural World Heritage sites can make to global goals.

If natural World Heritage sites are a litmus test for conservation, we remain short of our goal to achieve a positive future for these places, which represent the best of nature. In addition to protecting global biodiversity, natural World Heritage sites offer vital contributions to human well-being. Looking ahead, efforts will be needed globally, regionally, and on the ground to conserve and protect the precious values of these places. The IUCN World Heritage Outlook aims to continue contributing to this important effort for people and the planet. 


\section{References}

1. Conservation Measures Partnership (CMP) (2008). CMP Direct Threats Classification v 1.1 [online]. Available at: https://cmp-openstandards.org/library-item/threats-and-actions-taxonomies/

2. Great Barrier Reef Marine Park Authority (2009). Great Barrier Reef Outlook Report 2009. Townsville, Australia: Great Barrier Reef Marine Park Authority.

3. Hockings, M., Stolton, S., Leverington, F., Dudley, N. and Courrau, J. (2006). Evaluating Effectiveness. A framework for assessing management effectiveness of protected areas. 2nd edition. World Commission on Protected Areas Best Practice Protected Area Guidelines Series No. 14. Gland, Switzerland and Cambridge, UK: IUCN. Available at: https://doi.org/10.2305/UCN.CH.2005.PAG.14.en

4. Hockings, M., James, R., Stolton, S., Dudley, N., Mathur, V., Makombo, J., Courrau, J. and Parrish, J. (2008). Enhancing Our Heritage Toolkit. Assessing management effectiveness of natural World Heritage sites. World Heritage papers 23. Paris, France: UNESCO World Heritage Centre.

Available at: https://whc.unesco. org/document/100750

5. International Union for Conservation of Nature (IUCN) (2020). Conservation Outlook Assessments. The IUCN World Heritage Outlook [website]. https://worldheritageoutlook.iucn.org/explore-sites

6. IUCN (2020a). The IUCN World Heritage Outlook. Conservation Outlook Assessments - Guidelines for their application to natural World Heritage sites. Gland, Switzerland: IUCN. Available at: https://worldheritageoutlook. iucn.org/more/resources/conservation-outlook-assessments-guidelines-their-application-natural-world-heritage

7. Osipova, E., Shi, Y., Kormos, C., Shadie, P., Zwahlen. C. and Badman, T. (2014). IUCN World Heritage Outlook 2014. A conservation assessment of all natural World Heritage sites. Gland, Switzerland: IUCN. Available at: https://portals.iucn.org/library/node/44889

8. Osipova, E., Shadie, P., Zwahlen, C., Osti, M., Shi, Y., Kormos, C., Bertzky, B., Murai, M., Van Merm, R. and Badman, T. (2017). IUCN World Heritage Outlook 2. A conservation assessment of all natural World Heritage sites. Gland, Switzerland: IUCN. Available at: https://doi.org/10.2305/IUCN.CH.2017.17.en

9. Stolton S., Dudley, N. and Shadie, P. (2012). Managing Natural World Heritage. World Heritage Resource Manual. Paris, France: UNESCO. Available at: https://whc.unesco.org/document/117412

10. UNESCO (2008). Periodic Report Second Cycle Sections I and II. Paris, France: UNESCO World Heritage Centre. [website] https://whc.unesco.org/en/periodicreporting/

11. UNESCO (2018). Periodic Report Third Cycle Sections I and II. Paris, France: UNESCO World Heritage Centre. [website] https://whc.unesco.org/en/periodicreporting/

12. UNESCO (2019). Operational Guidelines for the Implementation of the World Heritage Convention. Paris, France: UNESCO World Heritage Centre. [website] https://whc.unesco.org/en/guidelines/ 
Natural World Heritage sites
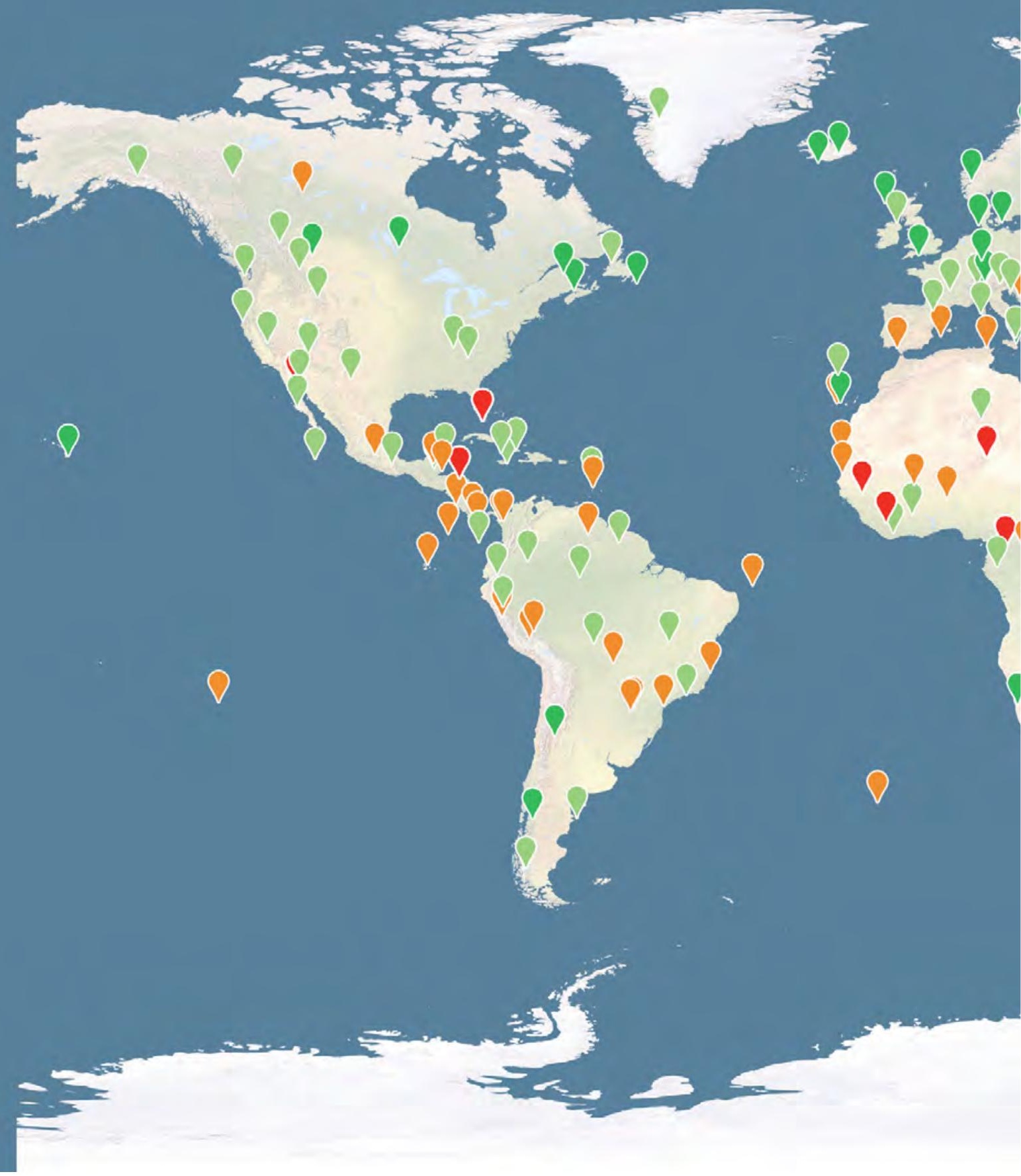


\section{Credits}

\section{Photos}

Cover: $\quad$ Manú National Park, Peru, @ Franz Lanting/ National Geographic Creative

Page iv: Greater Blue Mountains Area, Australia, CC BY NC 2.0 Chris Hearne

Page vii: $\quad$ French Astral Lands and Seas, France (C) IUCN/ Wendy Strahm

Page 6: $\quad$ Waterton Glacier International Peace Park, Canada/USA, CC BY 2.0 Bernd Thaller

Page 13: Vatnajökull National Park - Dynamic Nature of Fire and Ice, Iceland, (C) IUCN/ Bastian Bertzky

Page 15: Okavango Delta, Botswana, (C) IUCN/ Peter Howard

Page 19: Canaima National Park, Venezuela, CC BY SA 2.0 Fernando Flores

Page 22: Tropical Rainforest Heritage of Sumatra, Indonesia, CC BY 2.0 Dennis Keller

Page 34: Serengeti National Park, Tanzania, CC BY 2.0 Jorge Cancela

Page 40: Wadi Rum Protected Area, Jordan, CC BY 2.0 Lawrence Murray

Page 46: Dong Phayayen-Khao Yai Forest Complex, Thailand, CC BY SA 2.0 Thai National Parks

Page 52: Tongariro National Park, New Zealand, CC BY NC 2.0 Drouyn Cambridge

Page 58: High Coast/ Kvarken Archipelago, Finland/Sweden, (C) IUCN/ Elena Osipova

Page 64: Olympic National Park, USA, CC BY 2.0 Bernd Thaller

Page 70: Whale Sanctuary of El Vizcaino, Mexico, CC BY NC 2.0 Gilad Rom

Page 76: Chiribiquete National Park - "The Maloca of the Jaguar", Colombia, (c) IUCN/ Charles Besancon

\section{Graphics}

All graphics in this publication were developed by IUCN and Guilder Design, and are under copyright with IUCN, unless stated otherwise.

\section{Maps}

\section{World Heritage sites source:}

UNEP-WCMC and IUCN (2020). Protected Planet: World Heritage sites database; The World Database on Protected Areas (WDPA) [On-line], [version 10/2020],Cambridge, UK: UNEP-WCMC and IUCN. Available at: www. protectedplanet.net. Protected Planet $\AA$ is a joint product of UNEP and IUCN, managed by UNEP-WCMC and IUCN working with governments, communities and collaborating partners.

\section{Administrative boundaries sources:}

Esri, HERE, Garmin, FAO, NOAA, USGS, (c) OpenStreetMap contributors, and the GIS User Community.

\section{Oceans, lakes and terrain basemaps sources:}

Natural Earth: https://www. naturalearthdata.com/. Maps throughout this report were created using ArcGIS® software by Esri. ArcGIS ${ }^{\circ}$ and ArcMap ${ }^{\top M}$ are the intellectual property of Esri and are used herein under license. Copyright (C) Esri. All rights reserved. For more information about Esriß software, please visit www.esri.com. 



\section{IUCN}

INTERNATIONAL UNION

FOR CONSERVATION OF NATURE

WORLD HEADQUARTERS

Rue Mauverney 28

1196 Gland, Switzerland

mail@iucn.org

Tel +41229990000

Fax +41229990002

www.iucn.org

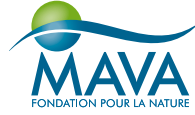

